Prepared for the U. S. Department of Energy Assistant Secretary for Resource Applications Grand Junction Office, Colorado

\title{
DEATH VALLEY $1^{\circ} \times 2^{\circ}$ NTMS AREA CALIFORNIA AND NEVADA
}

DATA REPORT

NATIONAL URANIUM RESOURCE EVALUATION PROGRAM

HYDROGEOCHEMICAL AND STREAM SEDIMENT RECONNAISSANCE

J. R. $\operatorname{coOK}$

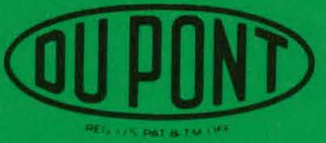

E. I. du Pont de Nemours \& Co. Savannah River Laboratory Aiken, SC 29808 


\section{DISCLAIMER}

This report was prepared as an account of work sponsored by an agency of the United States Government. Neither the United States Government nor any agency Thereof, nor any of their employees, makes any warranty, express or implied, or assumes any legal liability or responsibility for the accuracy, completeness, or usefulness of any information, apparatus, product, or process disclosed, or represents that its use would not infringe privately owned rights. Reference herein to any specific commercial product, process, or service by trade name, trademark, manufacturer, or otherwise does not necessarily constitute or imply its endorsement, recommendation, or favoring by the United States Government or any agency thereof. The views and opinions of authors expressed herein do not necessarily state or reflect those of the United States Government or any agency thereof. 


\section{DISCLAIMER}

Portions of this document may be illegible in electronic image products. Images are produced from the best available original document. 
This report is released without standard editorial and technical review in order to make the information available as soon as possible to interested organizations and to assist the search for uranium resources.

\section{DISCLAIMER}

This report was prepared as an account of work sponsored by the United States Government. Neither the United States nor the United States De. partment of Energy, nor any of their employees, make any warranty, ex. press or implied, or assumes any legal liability or responsibility for the accuracy, completeness, or usefulness of any information, apparatus, pro duct, or process disclosed, or represents that its use would not infringe privately owned rights. Reference herein to any specific commercial pro. duct, process, or service by trade name, mark, manufacturer, or otherwise, does not necessarily constitute or imply its endorsement, recommendation. or favoring by the United States Government or any agency thereof. The views and opinions of authors expressed herein do not necessarily state or reflect those of the United States Government or any agency thereof.

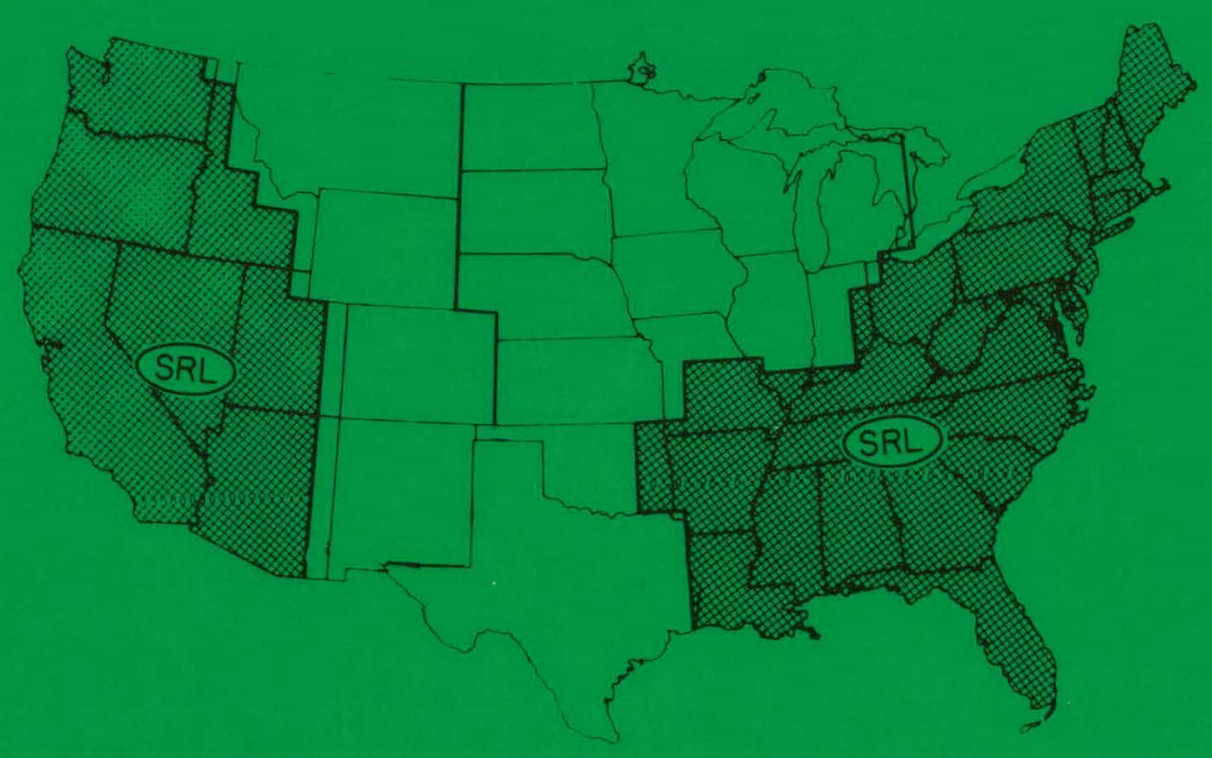


DEATH VALLEY $1^{\circ} \times 2^{\circ}$ NTMS AREA CALIFORNIA AND NEVADA

\section{DATA REPORT}

\section{NATIONAL URANIUM RESOURCE EVALUATION PROGRAM}

HYDROGEOCHEMICAL AND STREAM SEDIMENT RECONNAISSANCE

by

J. R. Cook

Approved by

M. L. Hyder

Analytical Chemistry Division

Publication Date: April 1980

E. I. du Pont de Nemours \& Co. Savannah River Laboratory

Aiken, SC 29808

PREPARED FOR THE U. S. DEPARTMENT. OF ENERGY UNDER CONTRACT OE ACO9.76SROOOUI 
This data report presents results of ground water and stream sediment reconnaissance in the National Topographic Map Series (NTMS) Death Valley $1^{\circ} \times 2^{\circ}$ quadrangle. Stream sediment samples were collected from small streams at 649 sites or at a nominal density of one site per 20 square kilometers (eight square miles). Ground water samples were collected at 62 sites or at a nominal density of one site per 220 square kilometers ( 87 square miles). Neutron activation analysis (NAA) results are given for uranium and 16 other elements in sediments, and for uranium and 8 other elements in ground water and surface water. Mass spectrometry results are given for helium in ground water. Field measurements and observations are reported for each site. Analytical data and field measurements are presented in tables and maps. Statistical summaries of data and a brief description of results are given. A generalized geologic map and a summary of the geology of the area are included.

Key data are presented in page-sized hard copy. Supplementary data are on microfiche.

Key data from ground water sites (Appendix A) include (1) water chemistry measurements ( $\mathrm{pH}$, conductivity, and alkalinity), (2) scin$t$ illometer readings, and ( 3 ) elemental analyses $(\mathrm{U}, \mathrm{Br}, \mathrm{Cl}, \mathrm{F}, \mathrm{He}$, $\mathrm{Mn}, \mathrm{Na}$, and $\mathrm{V})$. Supplementary data include site descriptors, tabulated analytical data for Al, Dy, and Mg, and histograms and cumulative frequency plots for all eleutents.

Key data from stream sediment sites (Appendix B) include (1) water quality measurements ( $\mathrm{pH}$, conductivity, and alkalinity), (2) important elemental analyses (U, Th, Hf, Ce, Fe, Mn, Sc, Na, $\mathrm{Ti}$, and $\mathrm{V}$ ), and ( 3 ) scintillometer readings. Supplementary data from stream sediment sites incliule sample site descriptors (stream characteristics, vegetation, etc.), additional elemental analygoo (Dy, Eu, La, Lu, Sw, and $\mathrm{Yb}$ ), and histograms and cumulative frequency plots for all elements. 
Introduction 7

Geologic Summary and Uranium Occurrences 11

Hydrology 22

Quality Assurance 26

Factors Affecting the Data 26

Results and-Discussion of the Data 30

Acknowledgments 30

Cited References 36

Appendices
A. Ground Water Reconnaissance Data. A-1
B. Stream Sediment Reconnaissance Data B-1
C. User's Guide to SRL Data Reports C-I 
1 Location Map for the Death Valley $1^{\circ} \times 2^{\circ}$ NTMS "Quadrangle 9

2 Codes for the 15' Quadrangles Used in the Death Valley $1^{\circ} \times 2^{\circ}$ NTMS Quadrangle 10

3 Location of the Death Valley Quadrangle on a Physingraphio Prnvineo Map 12

4 Areal Distribution of $\log (\mathrm{U} / \mathrm{Hf}$ ) in Stream Sediment 33

5 Areal Distribution of $\log (U / T h)$ in Stream Sediment 34

6 Areal Distribution of $\log (\mathrm{U} / \mathrm{Th}+\mathrm{H} f)$ in Stream Sediment 35 


\section{LIST OF. TABLES}

1 Radiometric Age Determinations from the Death Valley Quadrangle 21

2 Precipitation at Selected Weather Stations in the Death Valley $1^{\circ} \times 2^{\circ}$ NTMS Quadrangle 23

3 Precision of SRL 2.2 Analyses 27

4 Precision of SRL 3.1 Analyses 28

5 Precision of SRL 4.1 Analyses 29

6 Statistical Sumary of Field Measurements and Elemental Analyses - Ground. Water 31

7. Statistical Summary of Field Measurements and Elemental Analyses - Sediment 32 
Plate IA Geologic Map of the Death Valley Quadrangle

Plate 1B Radiometric Age Dates in the Death Valley Quadrangle

Plate IC Mineral Occurrences in the Death Valley Quadrangle

Plate 2. Ground Water Sample Site Locations in the Death Valley Quadrangle

Plate 3. Surface Sample Site Locations in the Death Valley Quadrangle

Plate 4 Uranium Distribution in Ground Waters of the Death Valley Quadrangle

Plate. 5 Uranium Distribution in Stream Sediments of the Death Valley Quadrangle

Plate 6 Thorium Distribution in Stream Sediments in the Death Valley Quadrangle

Plate 7 Conductivity Distributinn in Ground Waters of the Death Valley Quadrangle 
DATA REPORT: DEATH VALLEY $1^{\circ} \times 2^{\circ}$ NTMS QUADRANGLE:

CALIFORNIA AND NEVADA

\section{INTRODUCTION}

The National Uranium Resource Evaluation (NURE) program was established to evaluate domestic uranium resources in the continental United States and to identify areas favorable for uranium exploration. The Grand Junction office (GJO) of the Department of Energy (DOE) is responsible for administering and coordinating NURE program efforts. The Savannah River Laboratory (SRL) has responsibility for hydrogeochemical and stream sediment reconnaissance (HSSR) of 3.9 million square kilometers $(1,500,000$ square miles) in 37 eastern and western states. Other DOE laboratories are responstble for similar reconnalssance in the rest of the continental United States including Alaska. The significance of the distribution of uranium in natural waters and stream sediments will be assessed as an indicator of areas favorable for the location of uranium deposits.

The principal objectives of the NURE program are:

-: Increase geologic knowledge of U.S. urantum resources in regions where uranium ore bodies are known to exist and are candidate supplies under present and near-term market conditions.

- Complete assessment of lower cost potential uranium resources in the conterminous U.S. and Alaska.

- Improve reliability and validate resource estimates and increase confidence levels.

- Expand scope of uranium assessment to include higher cost and relatively unknown domestic resources that may be feasible uranium supply alternatives.

- Apply advanced technologies for detection and assessment of uranium resources.

DOE-GJO is responsible for administering and coordinating efforts to meet these objectives including distribution of reports. 
Inputs to the NURE program come from DOE prime contractors, DOEsponsored research and development, the uranium industry, U.S. Geological Survey, U.S. Bureau of Vines, other federal and state government agencies, and independent sources.

The NURE program consists of six parts:

1. Hydrogeochemical and Stream Sediment Reconnalssance Survey

2. Aerial Radiometric Survey

3. Intermediate Grade Resource Studies

4. World Claes Geologic Studies

5. Subsurface Geologic Investigation

6. Technology Application

The data presented here are reconnaissance data intended for use in identifying broad areas for further study. While care has been taken to provide reliable sampling and analyses, verification of individual analyses is beyond the scope of this report. The data should be viewed statistically because "one-point anomalies" may be misleading. Reglonal trends, however; should be reliable. With.careful consideration of regional geology, these data should provide reliable guides to areas warranting further study.

This report is one of a series presenting basic data obtained by SRL reconnalssance. In the interest of disseminating available data as soon as possible, only neutron activation analyses are reported here. Supplementary reports: will be issued later. All data will be available on magnetic tape from:

GJOIS Project

UCC-ND Computer Applications Department

4500 North Bullding

Oak Ridge National Laboratory

P.O. Box X

Oak Ridge, Tenn.: 37830

A brlef description of sampling and analytical procedures and a detailed description of the maps, tables, and figures contained in this report are presented in the SRL document Oser's Guide to SRI Data Reports included as Appendix C in th1s report. A summary of the SRL development program in support of the reconnaissance is available in SRL-NURE progress reports (SRL-138). SRL data reports (SRI-146) have been open-filed for other quadrangles (Figure 1).

Figure 2 summarizes the quadrangle abbreviations used in SRL sample identification numbers. 


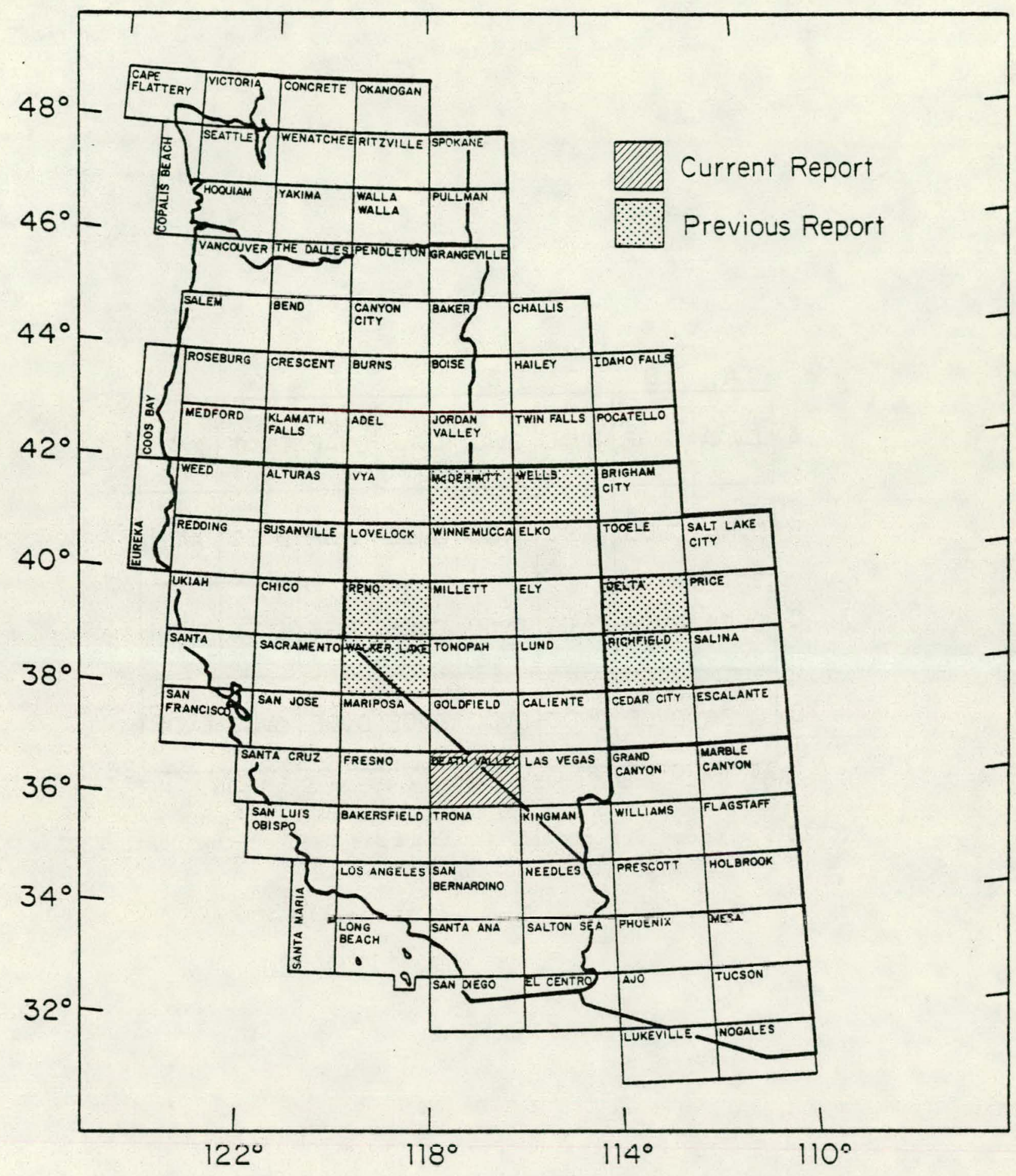

FIGURE 1. Location Map for the Death Valley $1^{\circ} \times 2^{\circ}$ NTMS Quadrangle 


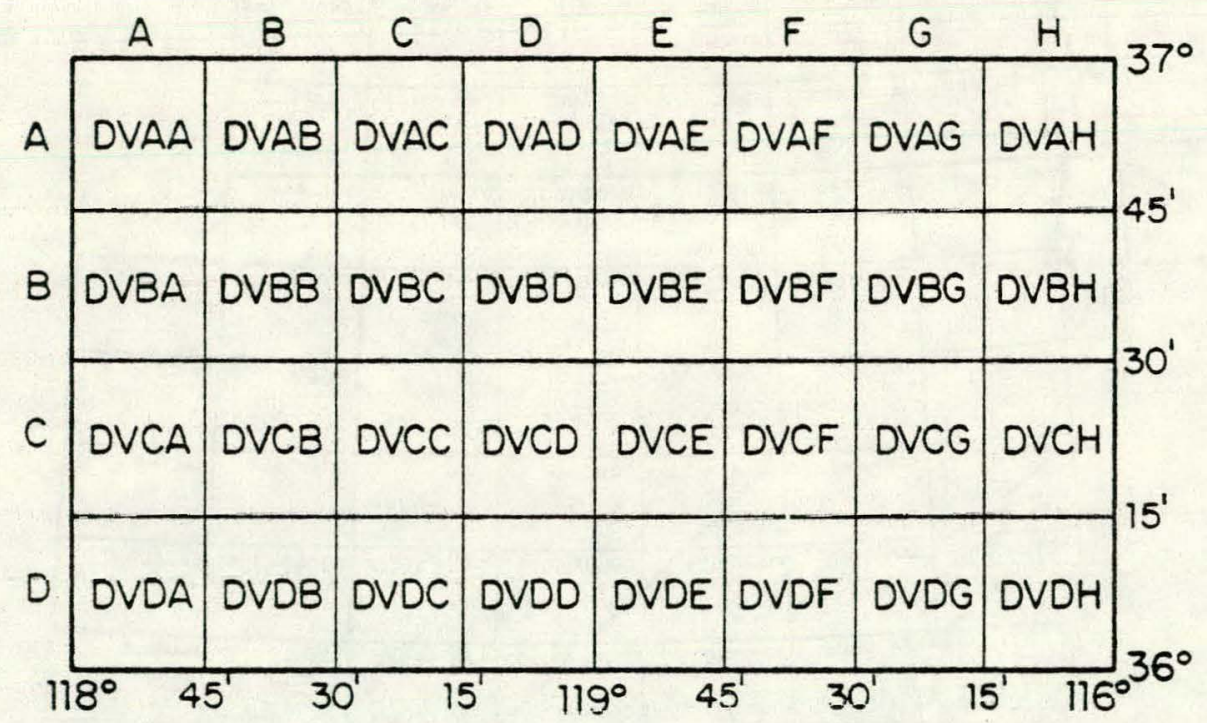

FIGURE 2. Codes for the 15' Quadrangles Used in the Death Valley $1^{\circ} \times 2^{\circ}$ NTMS Quadrangle 
GEOLOGIC SUMMARY AND URANIUM OCCURRENCES

\section{Geology}

\section{Surmary}

The Death Valley $1^{\circ} \times 2^{\circ}$ NTMS quadrangle area lies wholly within the Basin and Range physiographic province. The southern edge of the province terminates approximately along the Garlock Fault, about $50 \mathrm{~km}$ ( $30 \mathrm{mi})$ south of the area. The western limit of the Basin and Range Province terminates along the eastern edge of the Sierra Nevada Mountains, only a few miles west of the west edge of the area (Figure 3 ).

The rocks of the region are typical of those that occur in much of the southwestern part of the Basin and Range Province. The stratigraphic succession is moderately complete for rocks of late Precambrian through Paleozoic age. The strata rest on metamorphosed Precambrian rocks, are intruded by Mesozoic rocks, and are, in turn, overlain by Cenozoic sedimentary and volcanic flow rocks, and locally intruded by Cenozoic rocks (Hunt and Mabey, 1966; Streitz and Stinson, 1977).

The valleys and mountains are mostly fault-controlled, and most of the faults are probably younger than Miocene in age. Many displacements along faults have occurred during Quaternary time, as evidenced by the many scarps in Quaternary fan deposits. Many of the ranges have been tilted downward on the east caused by rotation on large normal faults. This rotation is demonstrated by the steep west slopes of the ranges, the common dip of strata to the east, and the common occurrence of the youngest strata on only the east slopes of ranges. The central parts of Death Valley and Panamint Valley have their lowest parts along the east side of the valleys, suggesting, too, that these valleys have been similarly rotated.

The most abundant of the recognized faults are normal faults that trend mainly north to northeast. The normal faults are closely related to northwest-trending lateral-slip faults, such as the Saline Valley fault zone and the northern Death Valley-Furnace Creek fault zone (Wright and Troxel, 1967, p. 948). 


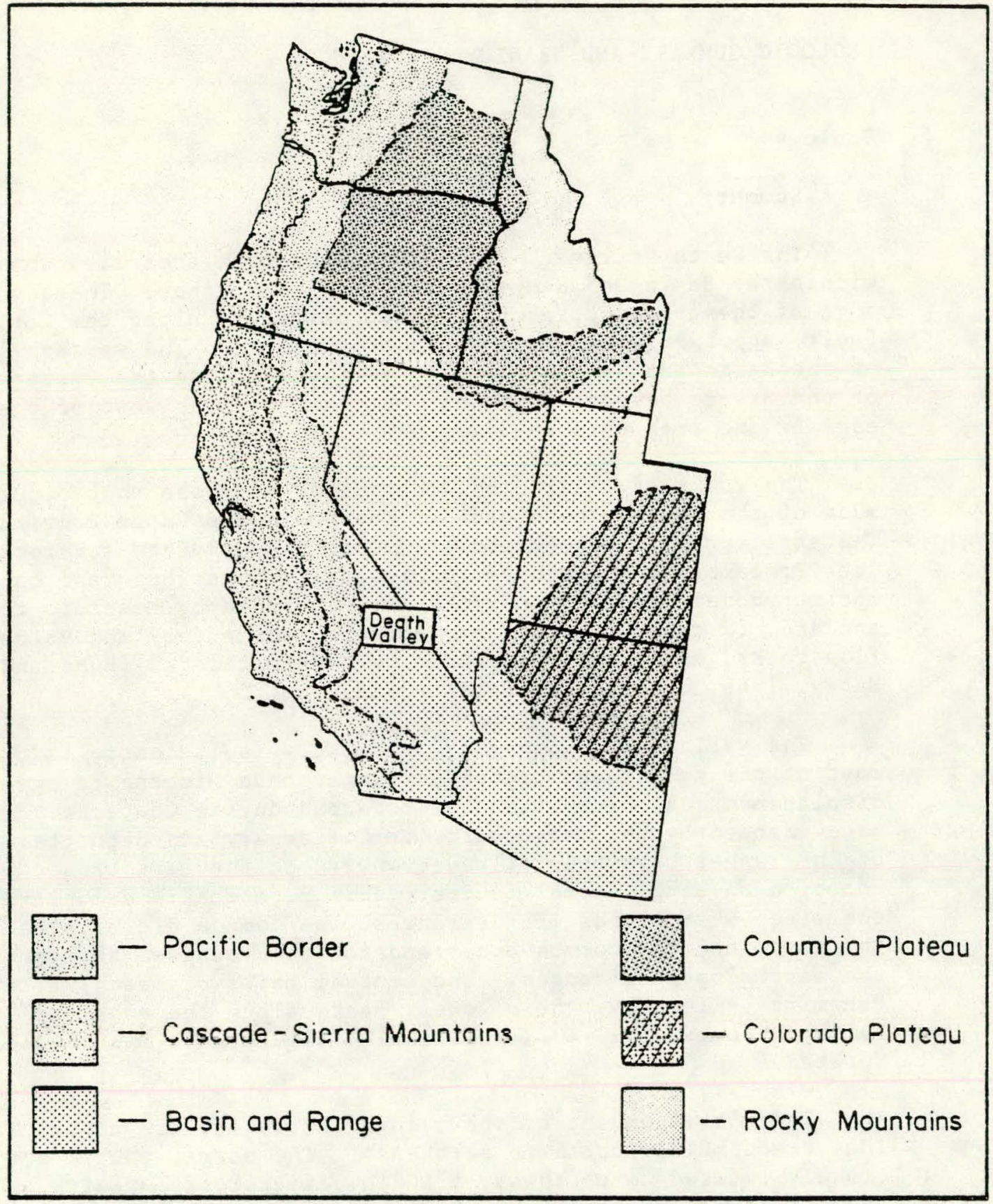

FIGURE 3. Location of the Death Valley Quadrangle on a Physiographic Province Map 


\section{Precambrian Rocks}

Precambrian rocks in the Death Valley $1^{\circ} \times 2^{\circ}$ NTMS quadrangle area are divided informally according to their relative age into three groups: Earlier Precambrian rocks, later Precambrian rocks, and even younger Precambrian strata that grade upward into Cambrian strata. The division of earlier and later Precambrian rocks is based, in part, on a strong contrast in the degree of metamorphism of rocks in the Death Valley region, as well as on a regional unconformity that separates them. The younger Precambrian rocks include sedimentary rocks that rest unconformably upon the earlier and later Precambrian rocks.

Some of the earlier Precambrian rocks that are exposed within the Death Valley quadrangle have been dated by radiometric methods. Rocks exposed in the east side of the Panamint Range, barely south of the south border of the quadrangle area, have yielded ages ranging from 1660 million years before the present (Myr BP) to 1780 Myr BP (Wasserberg and others, 1959; Silver and others, 1962). Because most of the rest of the earlier Precambrian rocks in this quadrangle are similar in composition and degree of metamorphism and lie beneath the regional unconformity, they are usually considered to be of the same general age.

Earlier Precambrian rocks are exposed low on the west side of the Panamint Range, in a small area of Tucki Mountain, and in the Black and Funeral Mountains. Diorite in the Black Mountains is shown on the geologic map ( $P$ late 1-A) as being earlier Precambrian, but its age has not been confirmed by radiometric methods, and is more likely Cenozoic in age. In the eastern portion of the Death Valley quadrangle, older Precambrian gneiss and schist consisting of quartz-muscovite-feldspar gneiss and quartz-muscovitebiotite schist are found in the Bullfrog Hills (Cornwall and Kleinhampl, 1964).

The earlier Precambrian rocks are meta-igneous and metasedimentary in origin, and most are strongly folliated. These rocks probably include rocks of the highest density in the area.

The later Precambrian rocks include the sedimentary strata of the Pahrump Group, which is divisible into the Crystal Spring Formation, the Beck Spring Dolomite, and the Kingston Peak Formation. In the Death Valley quadrangle, most of the Pahrump rocks are moderately to strongly metamorphosed with metamorphism increasing from south to north. From a relatively unmetamorphosed state in the east flank of the southern part of the Panarint Range, the rocks progressively increase in metamorphic grade to their northernmost outcrop limit in the northern part of the Panamint Range 
in Tucki Mountain. Similar rocks in the Funeral Mountains are increasingly metamorphosed from south to north (Wright and Troxel, 1967). For instance, siltstone in the southern part of the Funeral Mountains is the stratigraphic equivalent of garnetmuscovite schist or staurolite-muscovite schist in the northern part of the range.

Rocks of the Pahrump Group are sedimentary in origin except for a sill of diabase that generally occurs wherever the lowest formation, the Crystal Spring Formation, is exposed. The Pahrump Group crops out mainly as a nearly continuous band along the upper west flank of the Panamint Range and as a less-continuous band in the Funeral Mountains. The rocks that overlie the Pahrump Group are sedimentary in origin also and are, in large part, silicic clastic rocks. This third group of Precambrian rocks, the succession of younger rocks that overlies the Pahrump Group, includes successively, the Noonday Dolomite, the Johnnie Formation, and the Stirling Quartaite.

The Johnnie Formation is up to $1400 \mathrm{~m}$ (4500 ft) thick (Nolan, 1929 ) and consists of a lower quartzite and an upper quartzitic shale with a few dolomitic layers (Nolan, 1929). This formation is 2,500-feet thick in the Nopah Range (Hazzard, 1937).

The Stirling Quartzite (Nolan, 1929) is 975 to $1025 \mathrm{~m}$ ( 3200 to $3400 \mathrm{ft}$ ) thick and may be wide-spread in the Basin and Range Province (Stewart, 1966). This formation consists principally of gray to-pink quartzite with conglomerate, shale, and siltstone beds (Cornwal1, 19.72). The post-Pahrump sedimentary strata of Precambrian age underlie the entire crest and eastern flank of the Panamint Range, a large part of the Funeral Mountains, and small parts of the western flank of the Resting Spring Range.

The Wood Canyon Formation is of Precambrian and Cambrian age and consists of $640 \mathrm{~m}(2100 \mathrm{ft}$ ) of clastic material (Nolan, 1929). The unit has been divided into three members: a lower siltstone with quartzite and dolomitic beds, a middle quartzite with conglomeratic and siltstone beds, and an upper siltstone with shale and fine-grained quartzitic layers (Stewart, 1966).

\section{Paleoroic Rocks}

Paleozoic rocks exposed in the area of the Death Valley quadrangle are, for the most part, carbonate strata of marine origin. The carbonate strata tend to grade westward to clastic strata. Younger Paleozoic rocks contain less carbonate strata than older Paleozoic rocks. Paleozoic rocks are found in abundance in all 
of the ranges of the Death Valley quadrangle except the Black Mountains, the Greenwater Range, the Coso Range, and the area of the Nevada Test Site. They appear to be unmetamorphosed nearly everywhere except near margins of intrusive igneous rock masses. Late Precambrian and Paleozoic strata comprise most of Bare Mountain, the Specter Range, and the Spring Mountains in Nevada.

Cambrian rocks of the quadrangle include the Zabriskie Quartzite, the Carrara Formation, the Bonanza King Formation, and the Nopah Formation. The Zabriskie Quartzite (Hazzard, 1937) varies from $6 \mathrm{~m}(20 \mathrm{ft})$ thick in the Spring Mountains to $350 \mathrm{~m}$ ( $1150 \mathrm{ft})$ thick in the Bullfrog Hills (Cornwall, 1972). The Carrara Formation (Cornwall and Kleinhampl, 1961) conformably overlies the Zabriskie Quartzite and consists predominantly of interlayered shale and siltstone as much as $600 \mathrm{~m}$ (1960 ft) thick (Barnes and others, 1962).

The Bonanza King Formation. (Hazzard and Mason, 1936; Palmer and Hazzard, 1956) consists principally of thin-to-thick layered dolomite with some limestone, silty and sandy layers, and cherty zones (Cornwall and Kleinhampl, 1961). The unit is typically thick and is $923 \mathrm{~m}$ ( $3031 \mathrm{ft}$ ) thick in the Specter Range (Burchfiel, 1964). Barnes and others (1962) report a Middle and Late Cambrian Age for this formation from fossil studies at Yucca Flat.

The Nopah Formation (Hazzard, 1937) is $580 \mathrm{~m}$ (1900.ft) thick at Bare Mountain. It consists of three members, from bottom to top, the Dunderberg Shale, the Halfpint Member, and the Smokey Member. The Dunderberg Shale consists of about $30 \mathrm{~m}(100 \mathrm{ft})$ of paper-thin shale with some thin interbeds of limestone. The Halfpint Member varies greatly in thickness from 0- to $580 \mathrm{~m}$ ( $1900 \mathrm{ft}$ ) thick and consists of flaggy limestone and dolomite (Christiansen and Barnes, 1966). The Smoky Member is about $490 \mathrm{~m}$ (1600 ft) thick at Bare Mountain and consists dominantly of dolomite (Barnes and Christiansen, 1967).

Ordovician rocks include the Yogonip Group, the Ely Springs Dolomite, and Eureka Quartzite. In the Death Valley quadrangle, the Pogonip Group includes, from bottom to top, the Goodwin Limestone, the Ninemile Formation, and the Antelope Valley Limestone (Ross, 1964). These formations are not shown individually on the geologic map (Plate 1-A). The Goodwin Limestone is a medium-tothick bedded, generally gray limestone varying in thickness from $358 \mathrm{feet}$ at Bare Mountain (Ross, 1964), to $308 \mathrm{~m}(1010 \mathrm{ft}$ ) in the Belted Range a few miles north of the quadrangle (Cornwal1, 1972). The Ninemile Formation is a thin-bedded limestone with increasing shale interlayers toward the bottom of the unit. The Antelope Valley Limestone ranges to $520 \mathrm{~m}$ ( $1700 \mathrm{ft})$ thick and consists of thick-bedded, gray limestone with irregular layers of silty limestone. 
The Ely Springs Dolomite (Westgate and Knopf, 1932) and the Eureka Quartzite (Hague, 1883) have been combined for display on the geologic map (Plate 1-A). The Eureka Quarzite ranges in thickness from 30 to $140 \mathrm{~m}$ ( 100 to $460 \mathrm{ft}$ ) (Ross and Longwell, 1964) and consists of white-to-grayish orange, well-rounded, finegrained, generally massive to faintly layered quartzite (Cornwall, 1972). The Ely Springs Dolomite ranges in thickness from $90 \mathrm{~m}$ (300 ft) at Bare Mountain to $140 \mathrm{~m}$ (450 ft) in the Specter Range and consists of medium- to dark-gray, thin-bedded, blocky dolomite with common chert (Poole and Christiansen, 1966).

Silurian rocks include the Roberts Mountain Formation, the Lone Mountain Dolomite, and undivided sedimentary rocks. The Roberts Mountain Formation (Merriam, 1940) is found in the Bullfrog Hills and on Bare Mountain in the Death Valley quadrangle and consists of 198 to $275 \mathrm{~m}$ (650 to $900 \mathrm{ft}$ ) of dolomite and limestone (Cornwall; 1972). Fossil studies by Merriam and Anderson (1942) iudicace a Middle silurian Age. The Lone Mountain Dolomite (Merriam, 1940) consists of about $975 \mathrm{~m}$ (3200 ft) of light-gray to dark-gray (lower part of the unit) dolomite (Cornwall, 1972).

Devonian rocks include the Devils Gate Limestone, the Nevada Formation, and undivided dolomitic sedimentary rocks. The Nevada Formation. (Hague, 1883; 1892, Merriam, 1940) consists of a lower dolomite and quartzite member and an upper, massive dolomite with a combined thickness of $490 \mathrm{~m}$ (1605 ft) in the Specter Range (Burchfiel, 1964). The Devils Gate Limestone (Merriam, 1940) consists of more than $300 \mathrm{~m}$ ( $1000 \mathrm{ft}$ ) of blue-gray limestone and minor dolomite with sandstone or quartzite layers common in the upper part of the formation (Poole and others, 1967). The Devils Gate Limestone is of Middle and Late Devonian age (Nolan and others, 1956).

The Monte Cristo Limestone of Mississippian age (Hewett, 1931) outcrops in the Spring Mountains (Vincelette, 1964), where the unit consists of $300 \mathrm{~m}(1000 \mathrm{ft})$ of fossiliferous cherty limestone. Fossile studies indicate an Early Mississippian age for the unit (Cornwal1, 1972).

The Pennsylvania Tippipah Limestone (Johnson and Hibbard, 1957 ) consists of $1100 \mathrm{~m}$ ( $3600 \mathrm{ft}$ ) of limestone and interlaypred silty limestone. Fossil studies indicate an Early Pennsylvania age for the unit (Gorduil and Poole, 1968). 
Mesozoic Rocks

Mesozoic rocks, mainly intrusive igneous rocks of granitic composition, occur west of Death Valley. A relatively thin, southeast-trending band of Iriassic marine sedimentary rocks and Jurassic-Triassic volcanic rocks crop out for a few miles along the southwest side of the Inyo Mountains. Isolated masses of metamorphosed sedimentary and volcanic rocks in the Coso Range also may be Mesozoic in age. Monolithic megabreccias of Mesozoic (?) or Tertiary (?) age are landslide masses composed almost entirely of dolomite and limestone from the Bonanza King Formation (Longwel1, 1951; Kupfer, 1960). The largest is $3 \mathrm{~km}$ ( $2 \mathrm{mi}$ ) long and $1.5 \mathrm{~km}$ ( $1 \mathrm{mi}$ ) wide (Cornwall, 1972).

\section{Tertiary Rocks}

The Tertiary rocks comprise intrusive and extrusive igneous rocks and nonmarine sedimentary rocks. Intrusive igneous rocks in the form of small plutons occur in the southern part of the Greenwater Range, the Black Mountains, and in the Panamint Range.

Extrusive and associated shallow intrusive rocks are common throughout the area of the Death Valley quadrangle. These rocks comprise a series of flows and pyroclastic rocks of probable early to mid-Tertiary age that are generally basic to intermediate in composition; a series of intrusive rocks, flows and pyroclastic rocks of middle-to-late Tertiary age that are intermediate-toacidic in composition; and basalt and andesite flows of very late Tertiary age. Because age determinations of most igneous rocks in the area are moderately scarce, ages of these rocks are not well established everywhere. Ages determined by the potassium-argon method for nine samples of Tertiary volcanic rocks from the Black Mountains range from 5.3 to 8.0 Myr BP (Fleck, 1970). Extrusive rocks in the southern part of the Greenwater Range have ages of 7 to 8.8 Myr BP (R. E. Brake, personal communication, 1979). Intrusive rocks in the Black Mountains are 22 Myr BP (Drewes, 1963) and in the Greenwater Range are 18.8 Myr BP(Chesterman, 1973). Most Tertiary volcanic rocks appear to have formed in highland areas.

Tertiary sedimentary rocks are estimated to range in age from Oligocene to Pliocene. Fine-grained lacustrine strata were laid down in several Tertiary basins which, for the most part, continue to be reflected by the modern topography. No single basin seems to have a complete section of Tertiary sedimentary rocks. The lake beds are subordinate to the coarse fan debris that was deposited over a much larger area than were the lake beds. 
Important Tertiary rocks include the Titus Canyon Formation, the Salyer Formation, the Wahmonie Formation, the Indian Trail Formation, and the Paintbrush Tuff. The Titus Canyon"Formation (Stock and Bode, 1935) is the basal Tertiary Unit along the California-Nevada border in the Death Valley quadrangle. The unit consists of terrestrial conglomerate, sandstone, siltstune, limestone, and tuff with a thickness ranging up to $900 \mathrm{~m}$ ( $3000 \mathrm{ft}$ ) (Cornwall and Kleinhampl, 1964).

The Salyer and Wahmonie Formations (Poole and others, 1965) are combined in the geologic map ( $P$ late $1-A$ ). These formations consist of a sequence of lava flows, volcanic breccia, tuff, and tuffaceous sandstones. The Sayler and wahmonie formations yield $\mathrm{K}$-Ar. dates of 12.5 to 12.9 Myr BP (Late Miocene age; Sornmall, 1972).

The Indian Trail Formation (Poole and McKeown, 1962) consists of ash-flow and ash-fall tuffs with an average thickness of $300 \mathrm{~m}$ $(1000 \mathrm{ft})$. K-Ar age dates are reported at 16 . Myr BP for the base of the formation (Orkild, 1965).

The Paintbrush Tuff (Orkild, 1965) consists of a wide variety of volcanic rocks which may have erupted from a caldera located concentrically around Timber Mountain, which is a few miles north of the Death Valley quadrangle in the vicinity of Yucca Mountain, Nevada. K-Ar dates ranging from 12.4 to 13.2 Myr BP indicate a Late Miocene age for the unit (Kistler, 1968).

\section{Tectonic History}

The structural history of the Death Valley quadrangle involves Mesozoic thrust faulting and Cenozoic normal and strikeslip faulting. Mesozoic intrusion followed or accompanied most of the thrust faulting, and Cenozoic extrusion is related to normal faulting. Strike-slip faulting is related to normal faulting.

The thrust faults are most common in ranges west of Death Valley, but some are exposed in the Grapevine Mountains, Nnpah Range, Bare Mountain, and the Spring Mountains. All of the thrust faults were formed during Mesozoic compression, resulting in west-to-east overthrusting.

The normal faults bound most mountain ranges and form closely-spaced swarms within most ranges. Movement along the faults occurred mostly during mid-Miocene time or later. Where clearly exposed, most of the faults dip steeply westward and flatcen down-dip. Many of them were formed by differential extension of blocks on opposite sides of strikeslip faults. Where extension has been extreme, volcanism accompanied extension, and perhaps some intrusion occurred. Rotation of some of the ranges accompanied normal faulting. 
The Las Vegas Valley shear zone crosses the northeastern corner of the Death Valley quadrangle, entering the quadrangle in Mercury Valley, extending northwest into an geoflexural bend (Longwe11, 1960). Locke and others (1940) believe the Las Vegas Valley shear zone connects to the northwest with the Walker Lane structural zone. The Las Vegas Valley shear zone displays rightlateral displacement of 44 to $66 \mathrm{~km}$ (25 to $40 \mathrm{mi}$ ) (Stewart and others, 1968).

Volcanic subsidence areas or calderas are located in the vicinity of the Bullfrog Hills, Nevada. Portions of two large calderas lie along the northern border of the Death Valley quadrangle in the vicinity of Yucca Mountain. The caldera centered on the Bullfrog Hills is approximately 17 to $22 \mathrm{~km}$ ( 10 to $13 \mathrm{mi}$ ) and is elongated in a northeasterly direction (Cornwall and Rleinhampl, 1964).

The large calderas associated with Timber Mountain (a few miles north of the Death Valley quadrangle) are overlapping, have an overall measurement of 25 by $33 \mathrm{~km}$ ( 15 by $20 \mathrm{mi}$ ) and are elongated northwest (Christiansen and others, 1965). The caldera at the Bullfrog Hills and those at Timber Mountain appear to have an age of about 11.0 to 12.4 Myr BP. (Cornwall, 1972).

\section{Mineral Occurrences}

\section{Oranium}

Uranium-bearing minerals are not known to occur in abundance in the area of the Death Valley quadrangle, and published information is lacking on the few known occurrences. The principal uranium occurrences are in Tertiary sedimentary rocks in the Coso Range, in sedimentary rocks of the Kingston Peak Formation in the Panamint Range, and in the Bullfrog Hills near Beatty; Nevada. (Troxel et al., 1957). Most of the granitic rocks within the limits of the Deatl Valley quadrangle have, at best, sparse pegmatite dikes. The basal conglomerate of the Precambrian Crystal Spring Formation may be a likely unit to seek radiometric refractory heavy minerals.

Beal (1978) reports three uranium claims staked during the period of 1976 and 1977 in the Death Valley quadrangle. These are the Ontario Prospect, located in Section 6, Township T 21 S, Range $\mathrm{R} 38 \mathrm{E}$, the Coso Claims located in Township T $20 \mathrm{~S}$, Range $\mathrm{R} 37 \mathrm{E}$, and the Coso Range Claims located in Township $T 19 \mathrm{~S}$, Range R $37 \mathrm{E}$. 


\section{Other Minerals}

A wide variety of both metallic and nonmetallic minerals and comrercial rock materials occur or have been mined from deposics that lie within the limits of the area encompassed by the Death Valley $1^{\circ} \times 2^{\circ}$ NTMS quadrangle (Plate $1-B$ ). Those metals that have been of most economic significance (in approximate order of value) are lead, gold, silver, tungsten, zinc, antimony, and iron. The nonmetallic and commercial rock materials (again in approximate order of value) are borate minerals, saline minerals, talc, volcanic rocks, and carbonate rocks (Norman and Stewart, 1951).

Sulfide minerals and the oxide minerals derived from them have been the principal sources of antimony, copper, lead, silver, and zinc. Most of the economic deposits and lesser occurrences of these metals lie within a belt about $17 \mathrm{~km}$ ( $10 \mathrm{mi}$ ) wide that extends fioil the suulliern part of the Inyo Mouncalds southeastward to Galena Canyon on the east side of the Panamint Range. These deposits occur chiefly in Paleozoic carbonate host rocks.

Tungsten occurs in sedimentary strata adjacent to granitic rocks in the Panamint Range, Hunter Mountain, and the Inyo Mountains. The principal tungsten mineral is scheelite, which occurs both in disseminated form and in veins. The known occurrences of tungsten mineralization lie along the northeast margin of the belt of sulfide minerals.

Saline minerals, including borates, are associated mainiy with Cenozoic lake-bed deposits. They occur at Owens Lake (soda), Saline Valley (salt), Furnace Creek Wash (borates), Death Valley (borates and salt), and near Shoshone (borates).

The principal areas of gold mineralization are in the Funeral Mountains, Panamint Range, Inyo Mountains, the Argus Range, and the area surrounding Rhyolite, Nevada. The gold deposits in California occur mainly in or adjacent to the northwest-trending belt of sulfide minerals, where it is usually. found in quartz veins either in Mesozoic granitic intrusive rocks or in adjoining sedimentary rooko. At Rhyolite, Nevada, the gold icculs iu Terbiary volcanic rocks.

\section{Radiometric Age Determinations}

Radiometric age determinations from the Death Valley quadrangle are presented in Table 1 and keyed to locations on Plate 1-B. A number of age dates are concentrated in the vicinity of the Nevada Test Site. where intense geologic studies were nade in support of nuclear armament testing. 
Table 1

Radiometric Age Determinations from the Death Valley Quadrangle

\begin{tabular}{|c|c|c|c|c|}
\hline Site $^{\star}$ & Age $* *$ & Rock Type & Mineral & Formation \\
\hline 1 & $12.4(0.4)$ & Tuff & Biotite & Paintbrush Tuff \\
\hline 2 & $19.4(0.9)$ & Rhyolite & Sanidine & \\
\hline 3 & $22.8(1.3)$ & Tuff & Sanidine & \\
\hline 4 & $11.3(0.4)$ & Rhyolite & Biotite & \\
\hline $5 a$ & $11.6(0.4)$ & Tuff & Biotite & Tuff of Transvaal \\
\hline $5 b$ & $11.2(0.3)$ & Tuff & Sanidine & Tuff of Transvaal \\
\hline $6 a$ & $12.6(1.1)$ & Tuff & Feldspar & Paintbrush Tuff \\
\hline $6 b$ & $11.3(1.1)$ & Tuff & Feldspar & Tuff of Transvaal \\
\hline $7 a$ & $12.7(0.6)$ & Tuff & Biotite & Chocolate Mtn Tuff \\
\hline $7 b$ & $12.5(0.6)$ & Tuff & Feldspar & Chocolate Mtn Tuff \\
\hline $8 a$ & $13.1(0.4)$ & Tuff & Biotite & Crater Flat Tuff \\
\hline $8 b$ & $12.9(0.4)$ & Tuff & Biotite & Crater Flat Tuff \\
\hline $9 a$ & $13.8(0.4)$ & Tuff & Biotite & Crater Flat Tuff \\
\hline $9 b$ & $14.1(0.4)$ & Tuff & Biotite & Crater Flat Tuff \\
\hline 10 & $2.0(0.6)$ & Basalt & Whole Rock & \\
\hline 11 & $13.2(0.4)$ & Tuff & Biotite & Paintbrush Tuff \\
\hline 12 & $15.0(0.6$ & $\operatorname{Tu} f \mathfrak{f}$ & Biotite & \\
\hline 13 & $13.4(0.4)$ & Rhyolite & Biotite & Calico Hills Rhyolite \\
\hline 14 & $10.4(0.3)$ & Tuff & Sanidine & Timber Mtn Tuff \\
\hline 15 & $10.5(0.3)$ & Tuff & Sanidine & Timber Men Tuff \\
\hline $16 a$ & $10.8(0.3)$ & Tuff & Sanidine & Timber Men Tuff \\
\hline $16 \mathrm{~b}$ & $10.8(0.5)$ & Tuff & Sanidine & Timber Mtn Tuff \\
\hline
\end{tabular}


Table 1. (continued)

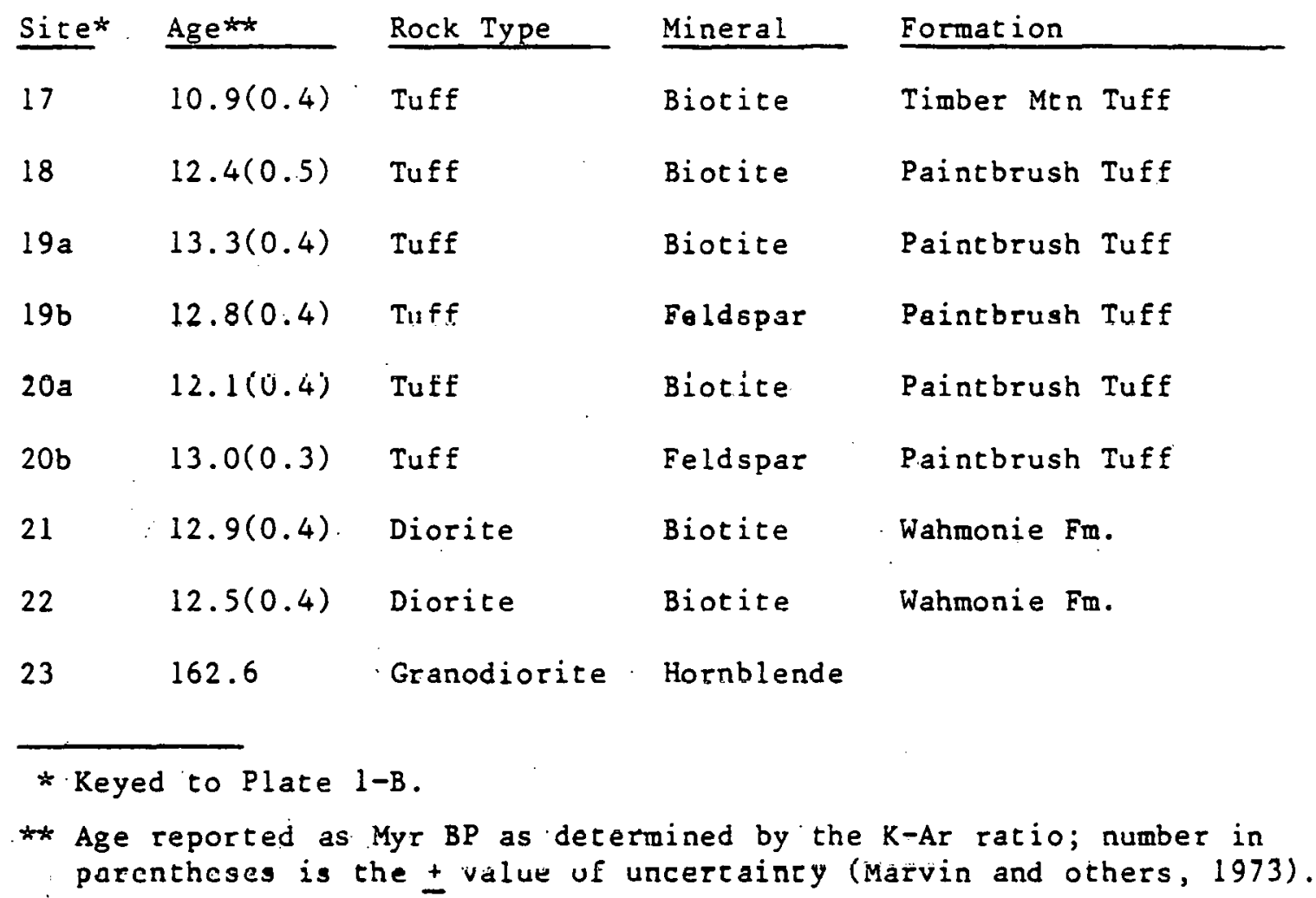

HYDROLOGY

Climate

The Death Valley $1^{\circ} \times 2^{\circ}$ NTMS quadrangle area is hot and dry, having hot sumers and mild winters. The average July temperature is about $32^{\circ} \mathrm{C}$; and the average January cemperature is about $9^{\circ} \mathrm{C}$. The higher sections in the western part of the Death Valley quadrangle average ahout $6^{\circ} \mathrm{C}$ loge, both oummer and wintel. The small amount of rainfall is fairly evenly distributed, ranging from about $50 \mathrm{~mm}$ in Death Valley to about $130 \mathrm{~mm}$ in the northwestern section. The area has almost no rainfall during the summer months (NOAA, 1977). Precipitation data for the months in which field sampling took place are presented in Table 2 . 
Table 2

Precipltation at Selected Weather Stations. In the Death Valley $1^{\bullet} \times 2^{\circ}$ NTMS Quadrangle

Weather Station Average Monthly Precipitation, mm

and Elevation, $m$ Jan. Feb. Mar. Apr. May June July Aug. Sept. Oct. Nov. Dec.

' Death Valley

w

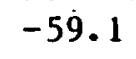

5.08

7.37

3.56

4.06

1.52

0.7 .62

3.56

2.79

2.54

1.78

7.11

5.33

Independence

1204

30.2

22.6

7.11

$8.64 \quad 3.30 \quad 1.52$

3.81

3.30

3. 81

5.59

$17.5 \quad 30.5$

Trona

516.6

18.

17.8

$11.2 \quad 5.59$

$1.52 \quad 1.52$

3.56

6.35

4.32

3.30

8.13

10.2 


\section{Geography}

The Death Valley quadrangle area is a good example of the topography of the Basin and Range Province. The contrast in slope between the valley floors and the flanking ridges is striking, and most of the valleys contain playas (Winograd and Thordarsen, 1975). Block-faulting during Pliocene and Pleistocene time has resulted in distinctive grabens, or down-faulted, trough-like valleys. The valleys do not appear to be filled with alluvium to the extent that other valleys are in other parts of the Basin and Range Province. Evidence of the down-faulting and incomplete filling of the valleys is indicated in Death Valley, where an extensive zone of land surface is below sea level. Pediments are scarce in the Nevada part of the map area.

A variety of Paleozoic rocks and Tertiary volcanic rocks make up the block mountains. The topographic relief between the northtrending mountain blocks and the intervening valleys is considerable. Peaks of Inyo Mountain in the northwest area rise to altitudes greater than $3200 \mathrm{~m}$, whereas altitudes in the Saline Valley below are less than $400 \mathrm{~m}$. The eastward sides of the mountain ranges tend to have slightly less topographic relief and have little or no vegetation.

During more humid Pleistocene time, several closed basins contained lakes: Evidence exists of the presence of Lake Manly drowning much of Death Valley during Pleistocene time (Thornhury, 1965). A century ago Owens Lake, at the extreme western part of the Death Valley quadrangle, had an area covering $300 \mathrm{~km}^{2}$ (Thomas and Phoenix, 1976), but diversion of water for human consumption in areas draining to it has now caused it to be an artflicial playa. Playas and alkali flats are rommon in the lower perts of several basins.

There are no.agricultural activities in the area.

The population of the area is virtually zero (U. S. Bureau of Census, 1970). There are a few National Park Service personnel in the Monument area to assist the thousands of visitors each year.

\section{Drainage and Hydrology}

Surface drainage is almost totally ephemeral. There are no through-flowing streams. Drainage from mountain slopes (as a result of infrequent storm runoff or as small springs) moves through gulches and gravel-filled channels (Miller, 1977). This runoff soon goes underground as it moves toward the centers of the basins. 
Darwin Creek near Darwin has a 15-year average discharge of $0.43 \mathrm{ft}^{3} / \mathrm{s}\left(0.0012 \mathrm{~m}^{3} / \mathrm{s}\right)$ and is the municipal supply for

Darwin. Salt Creek near Stovepipe Wells has had some measurable flow since 1974; but in dry years, will probably have no flow. Amargoso River at Tecopa has a discharge (15-year average) of $3.13 \mathrm{ft}^{3} / \mathrm{s}\left(0.089 \mathrm{~m}^{3} / \mathrm{s}\right)$, but often has no flow.

The consolidated rocks of the mountains are not sources of large supplies of water. Fractures near the land's surface are commonly dry; and fractures at greater depth are generally small and have little storage space for water. Springs from coves near the bases of mountains furnish some water supplies. Some deep circulation is thought to occur locally along some fracture and fault zones to the extent that water may move from a higher basin to a lower basin. Winograd and Thordarson (1975) postulate interbasin movement of water through fractured rocks from Amargosa Desert to Death Valley, and from the Nevada Test Site Area (in the northeast corner of the quadrangle) to a series of springs in Ash Meadow. The full extent of movement of water at great depths in the corisolidated rocks has not been determined.

An inventory of the groundwater in storage in the intermontane basins has been made (California Resources Agency, 1975): As much as 11 million acre-feet of water is in storage in the alluvium of Death Valley; but as is the case in all of the closed basins, most of the water is too highly mineralized for use. Much fresh groundwater occurs in the eastern third of the quadrangle where the basins are partly drained. Freshwater discharge is by irrigation wells, chiefly in the Ash Meadows area, and by springs in the same area. Considerable evaporation of groundwater occurs in low valley areas where the water table is near land surface; playas and salt flats characterize these discharge areas. Saline Valley, in the northwest corner of the Death Valley quadrangle, is a completely closed basin having a typical saltflat where groundwater is discharged by evaporation.

The quality of ground water has not been mapped. Potable, or less mineralized water, tends to occur near the borders of the valley. The more mineralized water occurs at greater depths or in the low center parts of the valleys. Brines occur in the vicinity of many playas, and the brines in Owens Lake contain 31 percent total solids, 10 times seawater salinity (Thomas and Phoenix, 1976). Groundwater temperatures range from about $10^{\circ}$ to $30^{\circ} \mathrm{C}$.

Most of the water from springs at higher elevations is of fairly good quality, having a dissolved solids content of less than $1000 \mathrm{mg} / \mathrm{L}$. The major ions in these waters vary with location, but generally are sodium chlorides and sulfates or are calcium and sodium bicarbonates. 


\title{
QUALITI ASSURANCE
}

\author{
Sample Collection
}

At least five percent of the sampled sites were routinely checked by SRL personnel (or by a specified subcontractor) to assure that the reported field locations were accurate. Based on these quality assurance checks, about $97 \%$ of the sampled sites were judged to be located as accurately as they could be plotted on county road maps. No evidence has been discovered of deliberate malfeasance by the sampling teams. Most sites that were mapped incorrectly were within 300 meters of their correct locations. Thus, the goals of a regional reconnaissance have not been compromised by mapping errors. Details of the quality assurance program are given elsewhere ( $S R L-138)$.

\section{Analytical Standards}

Sediment Standards SRL $2.2,3.1$, and 4.1 were analyzed along with NURE sediment samples primarily to provide precision data and routine systems checks for the analytical equipment and software. Results for standards analyzed with sediment samples are presented in Tables 3,4 , and 5 .

Three DOE intersite comparison standards were analyzed, one after each 230 sediment samples. An independent quality assurance program based on these standards is conducted for DOE by Ames (Iowa) Laboratory (D'Silva, et al.).

Every batch of twenty-five resin samples includes a blank resin sample. Resin blanks are not reacted with water samples. Every fifth batch includes a resin sample that was reacted with a standard solution containing nominally 0.278 ppb uranium. Resins reacted with DOE standard solutions were analyzed along with samples. See D'Silva, et al. for Ames Laboratory sumary.

\section{FACTORS AFTRCTINC THE DATA}

Approximately one-half of the Death Valley $1^{\circ} \times 2^{\circ}$ NTMS quadrangle was not available for sampling. The areas inuolved were the Death Valley National Monument and the Nevada Test Site. The number of samples was, therefore, one-half of what would normally be collected. The areal distribution of the samples that were collected was extremely discontinuous. Interpretation of such data on a fegional basis, a goal of the HSSR program, is difficult at best. 
TABLE 3

Statistical Sumary of Analytical Results for SRL 2.2 Sediment Standard

\begin{tabular}{|c|c|c|c|c|c|}
\hline Element & Number & $\begin{array}{l}\text { Mean, } \\
\text { ppm }\end{array}$ & $\begin{array}{l}\text { Coefficient of } \\
\text { Variation, } \%\end{array}$ & $\begin{array}{l}\text { Accepted } \\
\text { ppm }\end{array}$ & Value, \\
\hline U & 294 & 21.8 & 5.8 & 22.2 & \\
\hline Th. & 295 & 114 & 15.2 & 125 & \\
\hline $\operatorname{Hf}$ & 296 & 146 & 18.1 & 173 & \\
\hline Al & 289. & .7000 & 10.8 & 6500 & \\
\hline $\mathrm{Ce}$ & 288 & 534 & 15.5 & 614 & \\
\hline $\mathrm{Fe}$ & 273 & 6600 & 26.2 & 6700 & \\
\hline Mn & 266 & 275 & 15.8 & 300 & \\
\hline Sc & 297 & 3.41 & 26.8 & 3.9 & \\
\hline $\mathrm{Na}$ & 278 & 150 & 36.3 & 145 & \\
\hline $\mathrm{Ti}$ & 271 & 12,400 & 20.6 & 13,200 & \\
\hline v & 282 & 33.7 & 16.9 & 34.7 & \\
\hline Dy & 275 & 27.3 & 38.0 & $<22$ & \\
\hline Eu & 175 & 2.74 & 35.4 & 2.5 & \\
\hline La. & 276 & 279 & 17.5 & 301 & \\
\hline Lu & 253 & 2.55 & 13.2 & 2. 9 . & \\
\hline Sm & 280 & 47.7 & 38.2 & 51.3 & \\
\hline$Y b$ & 294 & 15.9 & 21.3 & 18.2 & \\
\hline
\end{tabular}




\section{TABLE 4}

Stacictioal Eummary of Aulytical Results for SRL 3.1 Sediment Standard

\begin{tabular}{|c|c|c|c|c|}
\hline Element & Number & $\begin{array}{l}\text { Mean, } \\
\text { ppm }\end{array}$ & $\begin{array}{l}\text { Coefficient of } \\
\text { Variation, } \%\end{array}$ & $\begin{array}{l}\text { Accepted } \\
\text { ppm }\end{array}$ \\
\hline $\mathrm{U}$ & 162 & 42.0 & 5.0 & 41.3 \\
\hline Th & 163 & 166 & 15.5 & 162 \\
\hline Hf & 25 & 2 & 104.8 & 7.4 \\
\hline $\mathrm{Al}$ & 132 & 37,000 & 16.6 & 30,600 \\
\hline $\mathrm{Ce}$ & 149 & 913 & 17.5 & 903 \\
\hline $\mathrm{Fe}$ & 160 & 16,000 & 19.3 & 15,200 \\
\hline Mn & 156 & 283 & 16.4 & 289 \\
\hline 30 & 169 & 4.55 & 36.7 & 4.19 \\
\hline $\mathrm{Na}$ & 167 & 1030 & 30.6 & 901 \\
\hline $\mathrm{Ti}$ & 114 & 5870 & 15.9 & 6100 \\
\hline$V$ & 147 & 50.6 & 17.0 & 54.4 \\
\hline Dy & 135 & 71.2 & 20.9 & $50 *$ \\
\hline Eu & 151 & 3.90 & 29.3 & 3.86 \\
\hline $\mathrm{La}$ & 153 & 470 & 16.4 & 443 \\
\hline Lu & 152 & 4.78 & 17.3 & 4.4 \\
\hline Sm & 159 & 68.8 & 36.6 & 69.2 \\
\hline Yb & 161 & 33.1 & 18.6 & 29.9 \\
\hline
\end{tabular}

* Only one laboratory reported dysprosium value. 
TABLE 5

Statistical Summary of Analytical. Results for SRL 4.1 Sediment Standard

\begin{tabular}{|c|c|c|c|c|}
\hline Element & Number & $\begin{array}{l}\text { Mean, } \\
\text { ppm }\end{array}$ & $\begin{array}{l}\text { Coefficient of } \\
\text { Variation, } \%\end{array}$ & $\begin{array}{l}\text { Accepted Value, } \\
\text { ppm }\end{array}$ \\
\hline $\mathrm{U}$ & 159 & 0.56 & 11.8 & 0.58 \\
\hline Th & 93 & 2.4 & 42.3 & 2.1 \\
\hline Hf & 122 & 3.2 & 46.4 & 4.4 \\
\hline Al & 112 & $\ldots 71,000$ & 15.7 & 66,700 \\
\hline $\mathrm{Ce}$ & 105 & 59 & 22.8 & 44 \\
\hline $\mathrm{Fe}$ & 156 & 85,500 & 14.6 & 87,300 \\
\hline $\mathrm{Mn}$ & 141 & 1850 & 16.8 & 1970 \\
\hline Sc & 158 & 20 & 34.4 & 21 \\
\hline $\mathrm{Na}$ & 153 & 18,800 & 15.6 & 16,100 \\
\hline $\mathrm{Ti}$ & 91 & 26,700 & 14.6 & 25,200 \\
\hline v & 136 & 259 & 16.1 & 273 \\
\hline Dy & 16 & 7.3 & 29.2 & $<22$ \\
\hline Eu & 79 & 1.47 & 37.2 & 1.16 \\
\hline $\mathrm{La}$ & 157 & 18.2 & 18.1 & 18.6 \\
\hline Lu & 129 & 0.22 & 31.4 & 0.28 \\
\hline $3 w$ & 152 & 3.4 & 24.6 & 4.2 \\
\hline $\mathrm{Yb}$ & 60 & 2.1 & 47.8 & 1.6 \\
\hline
\end{tabular}


Ground water samples were available at only 62 sites. In an area of this size, these represent too little data on which to base any conclusions, so none are made. The sparse analytical data are presented only for information (Table 6).

A sumary of neutron activation analyses (NAA) above analytical detection limits is summarized in Table 7 . The tabulated values are for sediments of less than 149 micrometers (U.S. Std. 100-mesh) collected from small streams. Sieved fractions of other sizes, or rock or soil samples, even though collected in the same region, might yield entirely different values because of mineralogical variations.

\section{RESULTS AND DISCUSSION OF THE DATA}

The highest uranium concentrations are associated with sediments derived from granites and acidic volcanics in the southwestern part of the Death Valley $1^{\circ} \times 2^{\circ}$ NTMS quadrangle. Symbol plot maps of $\log \mathrm{U} / \mathrm{Hf}$ and $\mathrm{U} / \mathrm{Th}$, Figures 4 and 5 , respectively, effectively define areas of high uranium associated with monazite and zircon, respectively. Figure 6 is a plot of the areal distribution of $\log \mathrm{U} /(\mathrm{Th}+\mathrm{HF})$. This figure shows an area in the western part of the quadrangle with a cluster of high values. The absolute uranium concentrations are not the greatest there, but the uranium is most likely not associated with the most common resistate minerals.

The symbol plot maps. (on microfiche) show that iron, scandium, and vanadium have. similar areal distributions. Iron and vanadium appear to correlate very elosely; $v^{+3}$ lias substicured for the $\mathrm{Fe}^{+3}$ ion in magmas. The presence of vanadium in the weathering environment may provide a means of forming insoluble uranyl vanadates.

\section{ACRNOWLEDGMENTS}

The geologic and mineral occurrence information was compiled for SRL by Bennie Troxel, Napa, California, and David E. Howell, Reno, Nevada. The hydrologic information was provided by Harry E. T.eprand, Raloigh, North Carnlina. 
TABLE 6

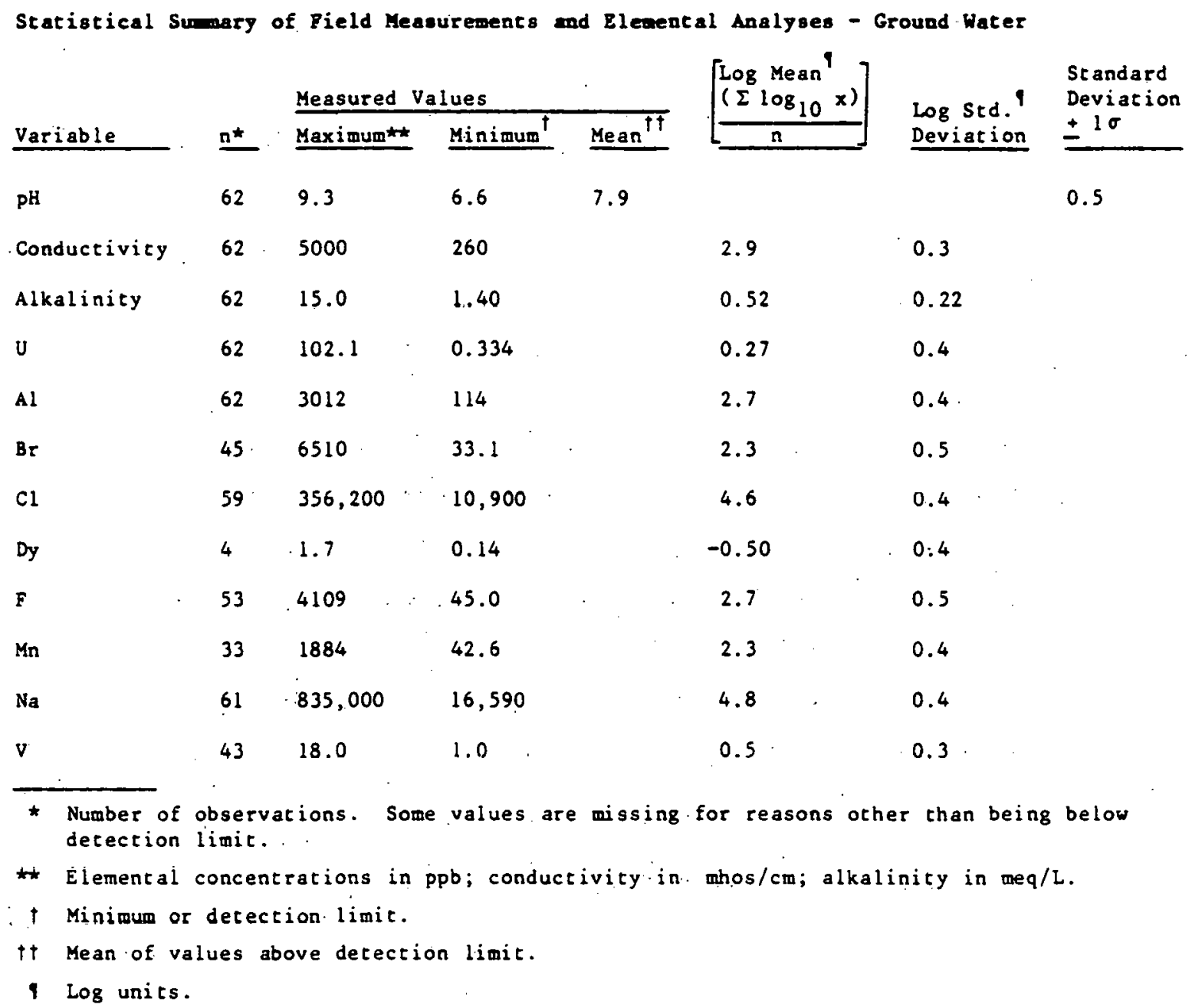




\section{TABIR 7}

Statistical Sumary of Field.Meraurements and Rlemental Analgses - Sediwent

\begin{tabular}{|c|c|c|c|c|c|}
\hline \multirow[b]{2}{*}{ Element } & \multirow[b]{2}{*}{$\underline{n}$} & \multicolumn{2}{|c|}{ Messured Values } & $\begin{array}{l}\log \text { Meantt } \\
{\left[\begin{array}{ll}\left(\Sigma \log _{10}\right. & x\end{array}\right]}\end{array}$ & \multirow{2}{*}{$\begin{array}{l}\text { Log. Std. } \\
\text { Deviation }\end{array}$} \\
\hline & & Maximum** & Minimumt & L & \\
\hline $\mathbf{U}$ & 622 & 25.5 & 0.7 & 0.58 & 0.15 \\
\hline Th & 501 & 177.0 & 5.0 & 1.15 & 0.24 \\
\hline Hf & 551 & 53.0 & 1.0 & 0.95 & 0.27 \\
\hline Al & 585 & 115,700 & 1100 & 4.78 & 0.17 \\
\hline $\mathrm{Ce}$ & 477 & $223^{\circ}$ & 16 & 1.88 & 0.21 \\
\hline$\Sigma e$ & 564 & 221,200 & 2,300 & 4.41 & 0.27 \\
\hline Sc & 596 & 31.0 & 0.10 & 0.78 & 0.30 \\
\hline $\mathrm{Ti}$ & 368 & 16,200 & 400 & 3.52 & 0.29 \\
\hline v & 558 & 540 & 10 & 1.82 & 0.30 \\
\hline Dy & 178 & 182 & 1.0 & 0.52 & 0.35 \\
\hline Eu & 278 & 6.7 & 0.5 & 0.19 & 0.22 \\
\hline La & 367 & 197 & 11.0 & 1.64 & 0.19 \\
\hline Lu & 216 & 1.7 & 0.4 & -0.27 & 0.13 \\
\hline $\mathrm{Sm}$ & 310 & 828 & 1.0 & 0.78 & 0.33 \\
\hline $\mathrm{Yb}$ & 213 & 42.5 & 1.1 & 0.48 & 0.25 \\
\hline
\end{tabular}

* Number of obcervations.

** Elemental concentrations in ppm.

$\uparrow$ Minimum of detection limit.

†† Mean of values above detection limit. 


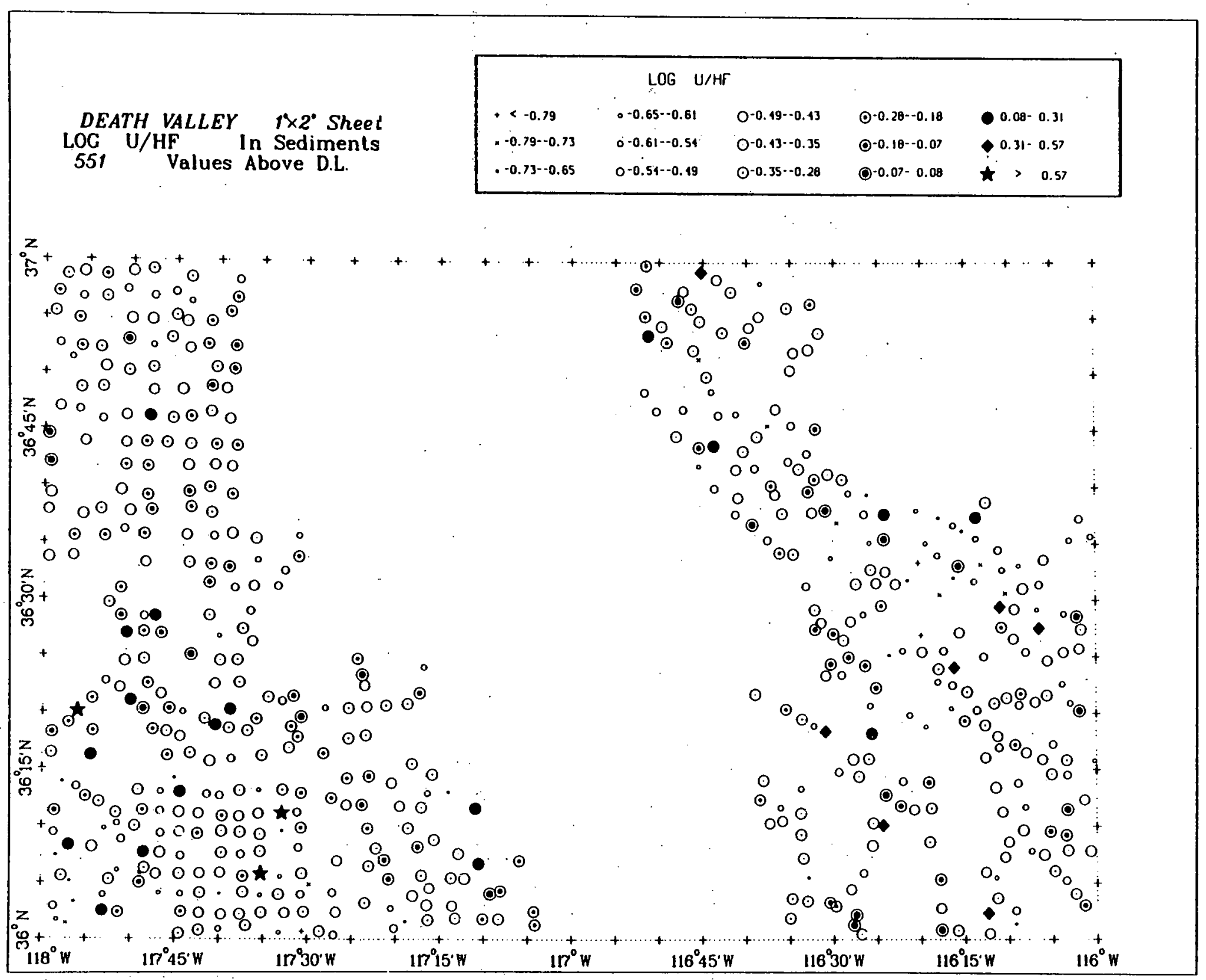

FIGURE 4. Areal Distribution of $\log (\mathrm{U} / \mathrm{Hf}$ ) in Stream Sediment 


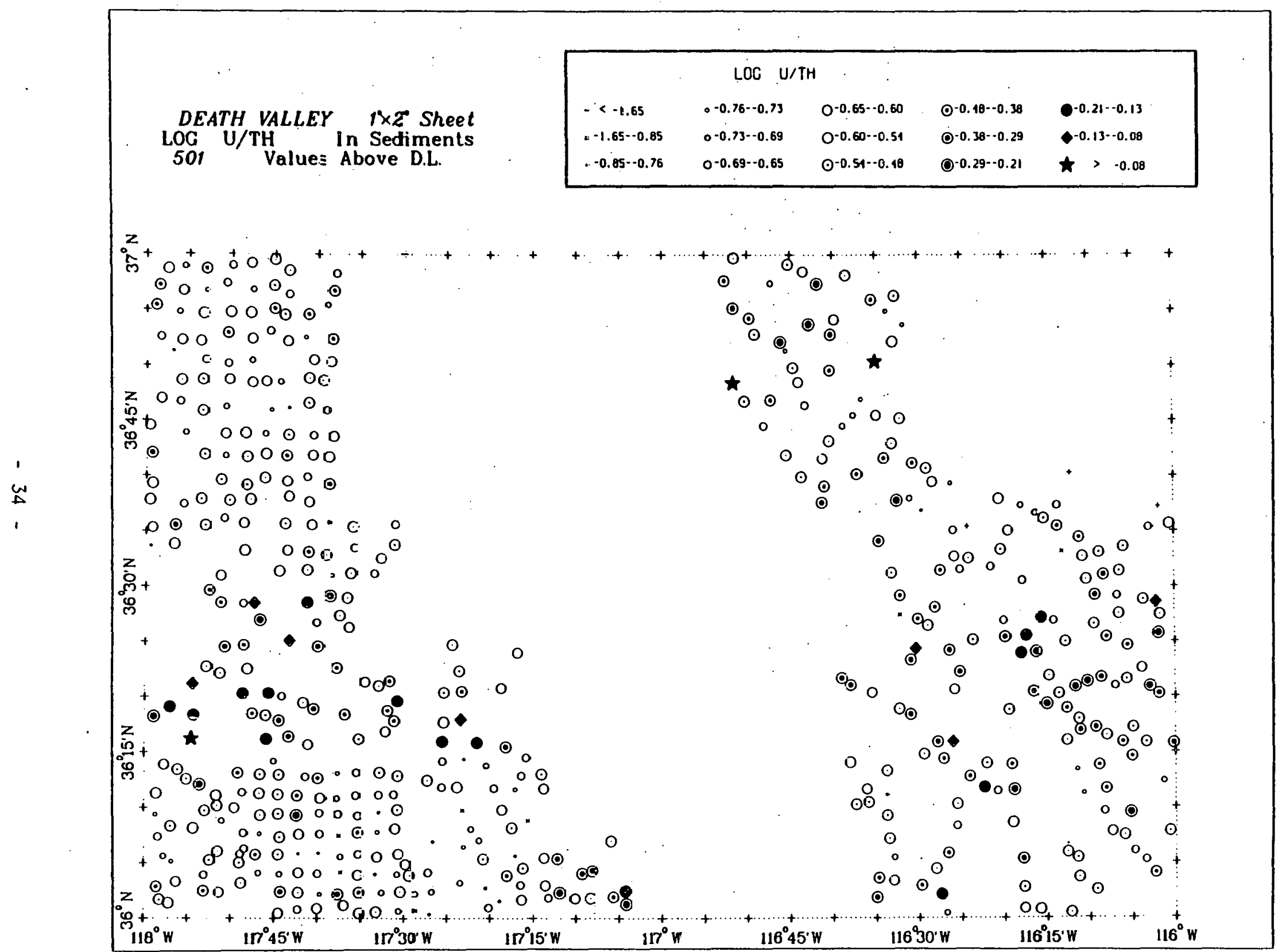

FIGURE 5. Areal Distribution of $\log (\mathrm{U} / \mathrm{Th})$ in Stream Sediment 


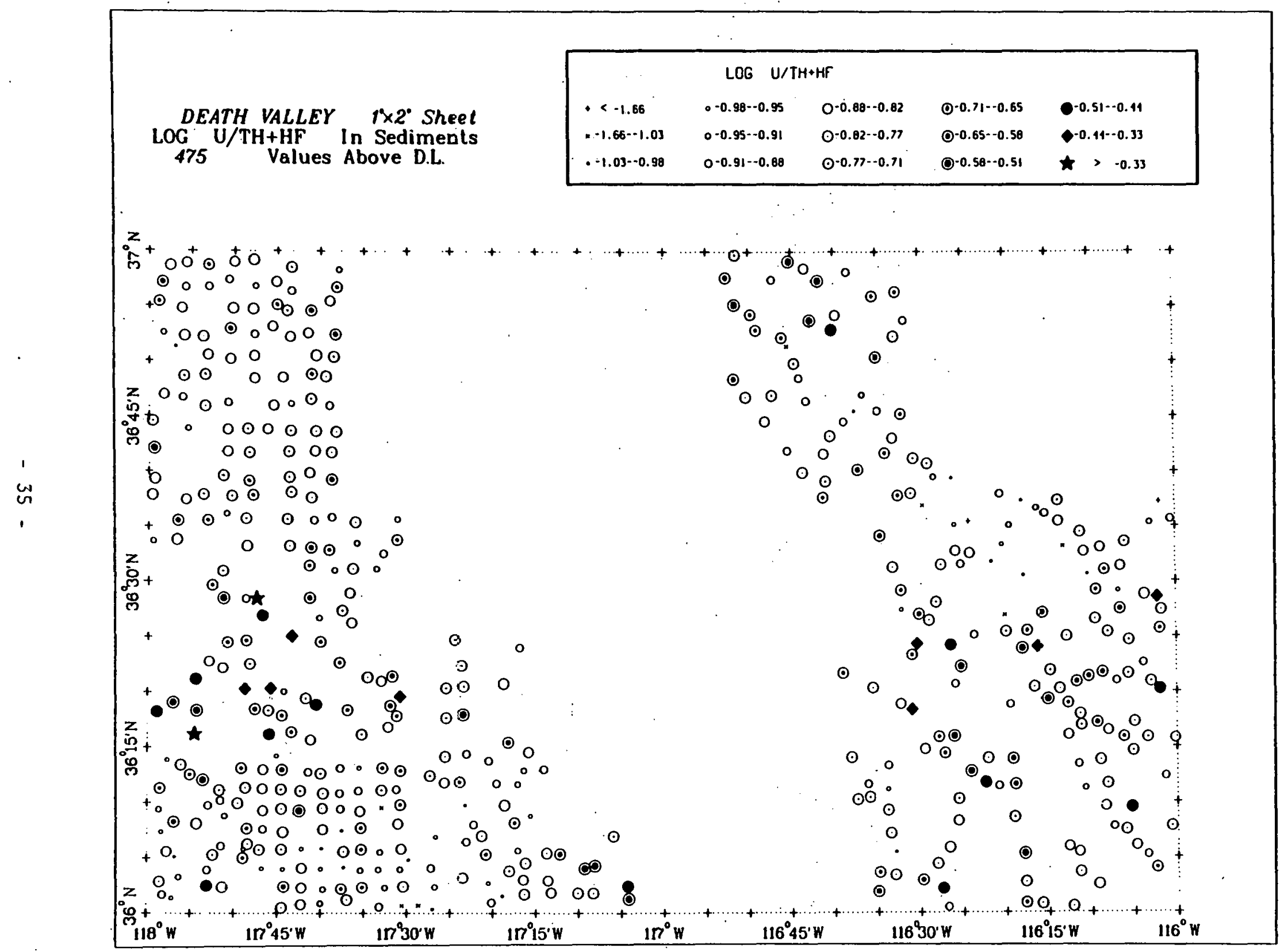

FIGURE 6. Areal Distribution of $\log (\mathrm{U} / \mathrm{Th}+\mathrm{Hf})$ in Stream Sediment 
Barnes, H., and Christiansen, R. L., 1967, Cambrian and Precambrian Rocks of the Groom District, Nevada, Southeastern Great Basin: U. S. Geol. Survey Bul1. 1244-G.

Barnes, H., Christiansen, R. L., and Byers, F. M., Jr., 1962, "Cambrian Carrara Formation, Bonanza King Formation, and Dunderberg Shale East of Yucca Flat, Nye County, Nevada," in Geological Survey Research 1962: U. S. Geol. Survey Prof. Paper 450-D, pp. D27-D31.

Beal, L. II., 1970, "Clalin Record Compllatioñ," in Larson, L. T., and Beal, L. H., Great Besin Geologic Framework and Uranium Favorabliti, Final Report: USERDA Report BFEC-GJO 76-020-E.*

Burchfiel, B. C., 1964, Precambrian and Paleozolc Stratigraphy of Specter Range Quadrangle, Nye County, Nevada: Amer. Assoc. Petroleum Geolog1sts Bull., Vol. 48, No. 1, pp. 40-56.

California Resources Agency, 1975, California's Ground Water: Dept. of Resources, Buli No. 118,134 pp.

Chesterman, C. W., 1973, Geology of the Northeast Quarter of the Shoshone Quadrangle, Inyo County, Callfornla: California Division of. Mines and Geology, Map Sheet 18.

Christiansen, R. L., and Barnes, H., 1966," "Three Members of the Upper Cambrian Nopah Formation in the Southern Great Basin," In Changes in Stratigraphic Nomeselature by the U. S. Geolngtical Survog, 1965: U. S. Gcol. Survey Bull. 1244-A, Pp. A49-A52.

Christiansen, R. L., Lipman, P. W., Orkild, P. P., and Byers, F. M., Jr., 1965, "Structure of the Timber Mountain Caldera, Southern Nevada, and Its Relation to Basin-Range Structure," in Geological Survey Research 1965: U. S. Geol. Survey Prof. Paper 525-B, pp. B43-B48.

Cornwall, H. R., 1972, Geology and Mineral Deposits of Southern Nye County, Nevada; Ncvada Burean nf Mines and Gulugy Bul1. 77. 
Cornwall, H. R., and Kleinhamp1, F. J., 1961, Geology of the Bare Mountain Quadrangle, Nevada: U. S. Geol. Survey Geol. Quad. Map GQ-157.

Cornwall, H. R., and Kleinhampl, F. J., 1964, Geology of Bullfrog Quadrangle and Ore Deposits Related to the Bullfrog Hills Caldera, Nye County, Nevada, and Inyo County, California: U. S. Geol. Survey Prof. Paper 454-J, Pp. J1-J25.

Drewes, H., 1963, Geology of the Funeral Peak Quadrangle, California, on the East Flank of Death Valley: U. S. Geol. Survey Prof. Paper 413.

D'Silva, A. P., Floyd, M. A., and Haas, W. J., Jr., Mult1laboratory Analytical Quality Control for the Hydrogeochemical and Stream Sediment Reconnalssance: Iowa State University, Ames Laboratory, Ames, Ia. A series of monthly reports sponsored by USDOE. Available from NTIS, Springfield, Va.

Fleck, R. J., 1970, Age and Tectonic Significance of Volcanic Rocks, Death Valley Area, Californla: Geol. Soc. Amer. Bul1., Vol. 81; No. 9, pp. 2807-2816.

Gordon, M., Jr., and Poole, F. G., 1968, "MississippianPennsylvania Boundary in Southwestern Nevada and Southeastern.California," in Nevada Test Site: Geol. Soc. Amer. Memoir 110, pp. 157-168.

Hague, A., 1883; Abstract of Report on the Geologg of the Eurekn District: U: S. Geol.: Survey 3d Ann. Rept., pp. 237-290.

Hague, A., 1892, Geology of the Eureka District, Nevada: U. S. Geol. Survey Monog. 20.

Hazzard, J. C., 1937, Paleozolc Section in the Nopah and Resting Springs Mountains, Inyo County, California: Calif..J. Mines Geol., Vol. 33, No. 4, Pp. 273-339.

Hazzard, J. C., and Mason, J. F., 1936, Middle Cambrian Formations of the Providence and Marble Mountalns, California: Geol. Soc. Amer. Bull., Vol. 47, No. 2, pp. 229-240.

Hewett, D. F., 1931, Geology and Ore Deposits of the Goodsprings Quadrangle, Nevada: U. S. Geol. Survey Prof. Paper 162.

Hunt, C. B., and Mabey, D. R., 1966, Stratigraphy and Structure, Death Valley, California: U. S. Geol. Survey Prof. Paper 494-A. 
Johnson, M. S., and Hibbard, M. J., 1957, Geology of the Atomic Energy Commission Nevada Proving Grounds Area, Nevada: U. S. Geol. Survey Bul1. 1021-K, Pp. 333-384.

Kistler, R. W., 1968, "Potassium-Argon Ages of Volcanic Rocks in Nye and Esmeralda Counties, Nevada," in Nevada Test Site: Geol. Soc. Amer. Memoir 110, pp. 251-262.

Kupfer, D. H., 1960, Thrust Faulting and Chaos Structure, Silurian Hills, San Bernardino County, California: Geol. Soc. Amer. Bul1., Vol. 71, No. 2, PP. 181-214.

Locke, A., Billingsley, P. R., and Mayo, E. B., 1940, Sierra Nevada Tectonic Patteruy: Geol. Soc. Amer. Bull., Vol. 51, No. 4, Pp. 513-540.

Longwe11, C. R., 1951, Megabreccia Developed Downslope from Large Faults: Amer. J. Sci., Vol. 249, No. 5, pp. 343-355.

Longwe11, C. R., 1960, Possible Explanation of Diverse Structural Patterns in Southern Nevada: Amer. J. Sci., Vol. 258-A (Bradley Volume), pp. 192-203.

Marvin, R. F., Mehnert, H. H., and McKee, E. H., 1973, A Summary of Radiometric Ages of Tertiary Volcanic. Rocks in Nevada and Eastern California; Part 3, Southeastern Nevada: Isochron/ West, No. 6, Pp. $1-30$.

Merriam, C. W., 1940, Devonian Stratigraphy and Paleontology of the Roberts Mountains Region, Nevada: Geol. Soc. Amer. Spec. Paper 25.

Merriam, C. W., and Anderson, C. W., 1942, Reconnaissance Survey of the Roberts Mountains, Nevada: Geol. Soc. Amer. Bull., Vol. 53, No. 12, pp. 1675-1727.

Miller, G. A, 1977, Appraisel of the Watex Resources of Death Valley, California-Nevada: U. S. Geol. Survey Open File Report 77-728.

NOAA, 1977, 0. S. Department of Commerce, National Climatic Center, Asheville, N. C.

Nolan, T. B., 1929, Notes on the Stratigraphy and-Structure of the Northwest Portion of Spring Mountain, Nevada: Amer. J. Sci., 5th ser., Vol. 17, pp. 461-472.

Nolan, T. B., Merriam, C. H., and Williams, J. S., 1956, The Stratigraphic Section in the Vicinity of Eureka, Nevada: U. S. Geol. Survey Prof. Paper 276. 
Norman, L. A., Jr., and Stewart, R. M., 1951, Mines and Mineral Resources of Inyo County: Calif. J. Mines Geol., Vol. 47, No. 1, pp. 17-223.

Orkild, P. P., 1965, "Paintbrush Tuff and Timber Mountain Tuff of Nye County, Nevada," in Changes in Stratigraphic Nomenclature by the U. S. Geological Survey, 1964: U. S. Geol. Survey Bul1. 1224-A, PP. A44-A51.

Palmer, A. R., and Hazzard, J. C., 1956, Age and Correlation of Cornfield Springs and Bonanza Ring Formations in Southeastern California and Southern Nevada: Amer. Assoc. Petroleum Geologists Bull., Vol. 40, No. 10, Pp. 2494-2499.

Poole, F. G., Baars, D. L., Drewes, H., Hayes, P. T., Ketner, K. B., McKee; E. D., Teichert, C., and Williams, J. S., 1967, "Devonian of the Southwestern United States," in International Symposium on the Devonian System, Calgary, Alberta, Sept. 1967, Calgary, Alberta: Soc. Petroleum Geolog. Vol. 1, pp. 879-912.

Poole, F. G., Carr, W. J., and Elston, D. P., 1965, "Salyer and Wahmonie Formations of Southeastern Nye County, Nevada," in Changes in Stratigraphic Nomenclature by the U. S. Geological Survey, 1964: U. S. Geol: Survey Bull: 1224-A, Pp. A36-A44.

Poole, F. G., and Christiansen; R. I., 1966, "Ely Springs Dolomite in the Southern Great Basin," in Abstracts for 1965: Geol. Soc: Amer. Spec. Paper 87, pp. 223-224.

Poole, F. G.:, and Mckeown, F. A., 1962, "Oak Spring Group of the Nevada Test Site and Vicinity, Nevada," in Geological Survey Research 1962: . U. S. Geol. Survey Prof. Paper 450-C, pp. C60-C62.

Ross, R. J., Jr., 1964, Middle and Lower Ordovician Formations in Southernmost. Nevada and Adjacent California: U. S. Geol. Survey Bull. 1180-C.

Ross, R. J., Jr., and Longwell, C. R., 1964, "Paleotectonic Significance of Ordovician Sections South of the Las Vegas Shear Zone," in Middle and Lower Ordovician Formations in Southernmost Nevada and Adjacent California: U. S. Geol. Survey Bull. 1180-C, pp. C88-C93.

Silver, L. T., Mckinney, C. R., and Wright, L. A., 1962, Some Precambrian Ages in the Panamint Range, Death Valley, California (Abstract); Geol. Soc. Amer. Special Report 68, P. 56 . 
SRL-138, Savannah River Laboratory Quarterly and Semiannual Reports, Hydrogeochemical and Stream Sediment Reconnaissance, National Uranium Resource Evaluation Program: E. I. du Pont de Nemours \& Co., Savannah River Laboratory, Aiken, S.C.

$\begin{aligned} \text { No. } & \text { Period } \\ 1 & \text { January-March } 1975 \\ 2 & \text { April-June } 1975 \\ 3 & \text { July-September } 1975 \\ 4 . & \text { October-December } 1975 \\ 5 & \text { January-March } 1976 \\ 6 & \text { April-June 1976 } \\ 7 & \text { July-September } 1976 \\ 8 & \text { October-December } 1976 \\ 9 & \text { Jauuary-March } 1977 \\ 10 & \text { April-June 1977 } \\ 11 & \text { July-September } 1977 \\ 12 & \text { October-December } 1977 \\ 13 & \text { January-March } 1978 \\ 14 & \text { April-September } 1978 \\ 15 & \text { October 1978-March } 1979 \\ 16 & \text { April-September } 1979\end{aligned}$

\begin{tabular}{l} 
SRL DoC. No. \\
\hline DPST $-75-138-1$ \\
DPST $-75-138-2$ \\
DPST $-75-138-3$ \\
DPST $-75-138-4$ \\
DPST $-76-138-1$ \\
DPST $-76-138-2$ \\
DPST $-76-138-3$ \\
DPST $-76-138-4$ \\
DPST $-77-138-1$ \\
DPST $-77-138-2$ \\
DPST $-77-138-3$ \\
DPST $-77-138-4$ \\
DPST $-78-138-1$ \\
DPST $-78-138-2$ \\
DPST $-79-138-1$ \\
DPST $-79-138-2$
\end{tabular}

DOE-GJO

DOC. NO.*

GJBX-5(76)

$G J B X-6(76)$

$G J B X-7(76)$

GJBX-8(76)

GJBX $-17(76)$

GJBX-27(76)

GJBX-63(76)

$G J B X-6(77)$

GJBX-35(77)

GJBX-55(77)

$G J B X-90(77)$

$G J B X-37(78)$

GJBX-66(78)

$G J B X-13(79)$

GJBX-86(79)

GJBX-160(79)

SRL-146, SRL-NURE Data Reports, E. I. du Pont de Nemours \& Co. Savannah River Laboratory, Aiken, S.C.

\begin{tabular}{|c|c|c|c|}
\hline No. & $\begin{array}{l}\text { NTMS } 1^{\circ} \times 2^{\circ} \\
\text { Quadrangle }\end{array}$ & SRL DOC. No. & $\begin{array}{l}\text { DOE-GJO } \\
\text { DOC. No.* }\end{array}$ \\
\hline 1 & Winston-Salemt & DPST $-77-146-1$ & GJBX-66(77) \\
\hline 2 & Spartanburg & DPST $-77-146=2$ & $G J B X-09(78)$ \\
\hline 3 & Charlotte & DPST $-78-146-1$ & GJBX $-40(78)$ \\
\hline 4 & Greenville & DPST $-78-146-2$ & GJBX-47(78) \\
\hline 5 & Winston-Salem $\dagger$ & DPST $-78-146-3$ & GJBX-58(78) \\
\hline 6 & Greensboro & DPST-78-146-4 & GJBX-74(78) \\
\hline 7 & Knoxvilile & DP ST $-7.8-146-5$ & GJBX-75(79) \\
\hline 8 & Scranton & DPST-78-146-6 & GJBX-02(79) \\
\hline 9 & Athens & DPST $-78-146-7$ & GJBX-20(79) \\
\hline 10 & Harrisburg & DPST $-79-146-1$ & GJBX-31(79) \\
\hline 11 & Portland & DPST $-79-146-2$ & GJBX-28(79) \\
\hline 12 & Glens Falls & DPST $-79-146-3$ & GJBX-44(79) \\
\hline 13 & Augusta & DPST $-79-146-4$ & GJBX $=15(79)$ \\
\hline 14 & Dyersburg & DPST $-79-146-5$ & GJBX-58(79) \\
\hline 15 & Poplar Bluff & DPST-79-146-6 & GJBXX-63(79) \\
\hline 16 & Hartford & DPST $-79-146-7$ & GJBX-94(79) \\
\hline 17 & Williams port & DPST $-79-146-8$ & $\operatorname{GJBX}-152(79)$ \\
\hline 18 & Newark & DPST-79-146-9 & (in process) \\
\hline 19 & Albany & DPST-79-146-10 & GJBX-140(79) \\
\hline 20 & At lanta & DPST $-7.9-146-11$ & GJBX-129(79) \\
\hline 21 & Delta, Richfield & DPST $-79-146-12$ & GJBX-161(79) \\
\hline 22 & Walker Lake & DPST $-79-146-13$ & (in process) \\
\hline 23 & McDermitt, Wells & DPST-79-146-14 & (in process) \\
\hline 24 & Reno & DPST $-79-146-15$ & (in process) \\
\hline 25 & Death Valley & DPST $-79-146-16$ & (this report) \\
\hline
\end{tabular}

$\uparrow$ Sediment only. $\dagger \dagger$ Ground water only. 
Stewart, J. H., 1966, "Correlation of Lower Cambrian and Some Precambrian Strata in the Southern Great Basin, California and Nevada," in Geological Survey Research 1966: U. S. Geol. Survey Prof. Paper 550-C, Pp. C66-C72.

Stewart, J. H., Albers, J. P., and Poole, F. G., 1968, Summary of Regional Evidence for Right-Lateral Displacement in the Western Great Basin: Geol. Soc. Amer. Bull., Vol. 79; No. 10, pp. 1407-1414.

Stock, C., and Bode, F. D., 1935, Occurrence of Lower Oligocene Mammal-Bearing Beds Near Death Valley, California: Natl. Acad. Sci. Proc., Vol. 21, No. 10, pp. 571-579.

Streitz, R., and Stinson, M. C., 1977, Geologic Map of California, Death Valley Sheet: Calif. Div. Mines and Geology, Sacramento, Calif.

Thomas, H. E., and Phoenix; D. A., 1976, Summary Appraisals of the Nation's Ground-Water Resources - California Region:

U. S. Geol. Survey Prof. Paper 813-E; 51 pp.

Thornbury, W. D., 1965, Regional Geomorphology of the United States: New York, John Wiley \& Sons, Inc., 609 Pp.

Troxel, B. W., Stinson, M. C., and Chesterman, C. W., 1957, Uranium: Calif. Div. of Mines Bull. 176, pp. 669-687.

U. S. Bureau of Census, Census of Population, 1970, and Census of Agriculture, 1970, Washington, D. C.

Vincelette, R. R., 1964, Structural Geology of the Mt. Stirling Quadrangle, Nevada, and Related Scale Model Experiments:

Ph.D. Thesis, Stanford Univ., Stanford, Calif.

Wasserberg, G. J., Wetherill, G. W., and Wright, L. A., 1959, Ages in the Precambrian of Death Valleg, California

(Abstract): ' leophysical Res., Vol. 64, No. 8, pp. 1129-1130.

Westgate, L. G., and Knopf, A, 1932, Geology and Ore Deposits of the Pioche District, Nevada: U. S. Geol. Survey Prof. Paper 171 .

Winograd, I. J., and Thordarson, W., 1975, Bydrogeologic and Eydrogeochemical Framework, South Central Great Basin, Nevada - California, with Special Reference to the Nevada Test Site: U. S. Geol. Survey Prof. Paper 712-C, pp. C1-Cl26. 
Wright, L. A., and Troxel, B. W., 1967, Limitations on RightLateral, Strike-Slip Displacement, Death Valley and Furnace Creek Fault Zones, California: Geol. Soc. Amer. Bull., Vol. 78, No. 8, pp. 933-950.

* DOE-GJO reports are available on microfiche from the Grand Junction Office, DOE, for $\$ 6.00$. Prepaid orders should be sent to Bendix Field Engineering Corporation, Technical Library, P.O. Box 1569, Grand Junction, CO 81501. Checks or money orders should be made out to Bendix Field Engineering Corporation, the operations contractor for DOE's Grand Junction office. 
Key data reported for ground water sites include:

- water chemistry measurements ( $\mathrm{pH}$, conductivity, and alkalinity)

- information on well water source

- elemental analyses (in order of appearance in figures) for $U$, $\mathrm{Br}, \mathrm{Cl}, \mathrm{F}$, He, $\mathrm{Mn}, \mathrm{Na}$, and $\mathrm{V}$.

\section{FIGURES (on microfiche):}

Areal Distribution, Log Histograms, and Cumulative Frequency Plots for $\mathrm{pH}$; Conductivity, Alkalinity, $\mathrm{U}, \mathrm{Br}, \mathrm{Cl}, \mathrm{F}$, He, $\mathrm{Mn}, \mathrm{V}, \mathrm{Al}, \mathrm{Dy}$, and $\mathrm{Mg}$.

TABLES

A-1 Key Field Measurements and Analytical Data - Ground Water

A-2 Supplementary Field and Analytical-Data - Ground Water (on microfiche) 
T2BLE A-I TABULAIION OO KEY FIELD MEASIIREMENIS AND ANALYIICAL OATA -GPOUND HATEP-DEATH VALLEY SHCET

$J$ BP CL F MN NA AND $V$ CLEMENIAL CONCENIPA-IONS IN PPB.
HE IN PPM IN ? CC AIR GAF ABOVE 300 CC HEO. SCINI IN CPS.

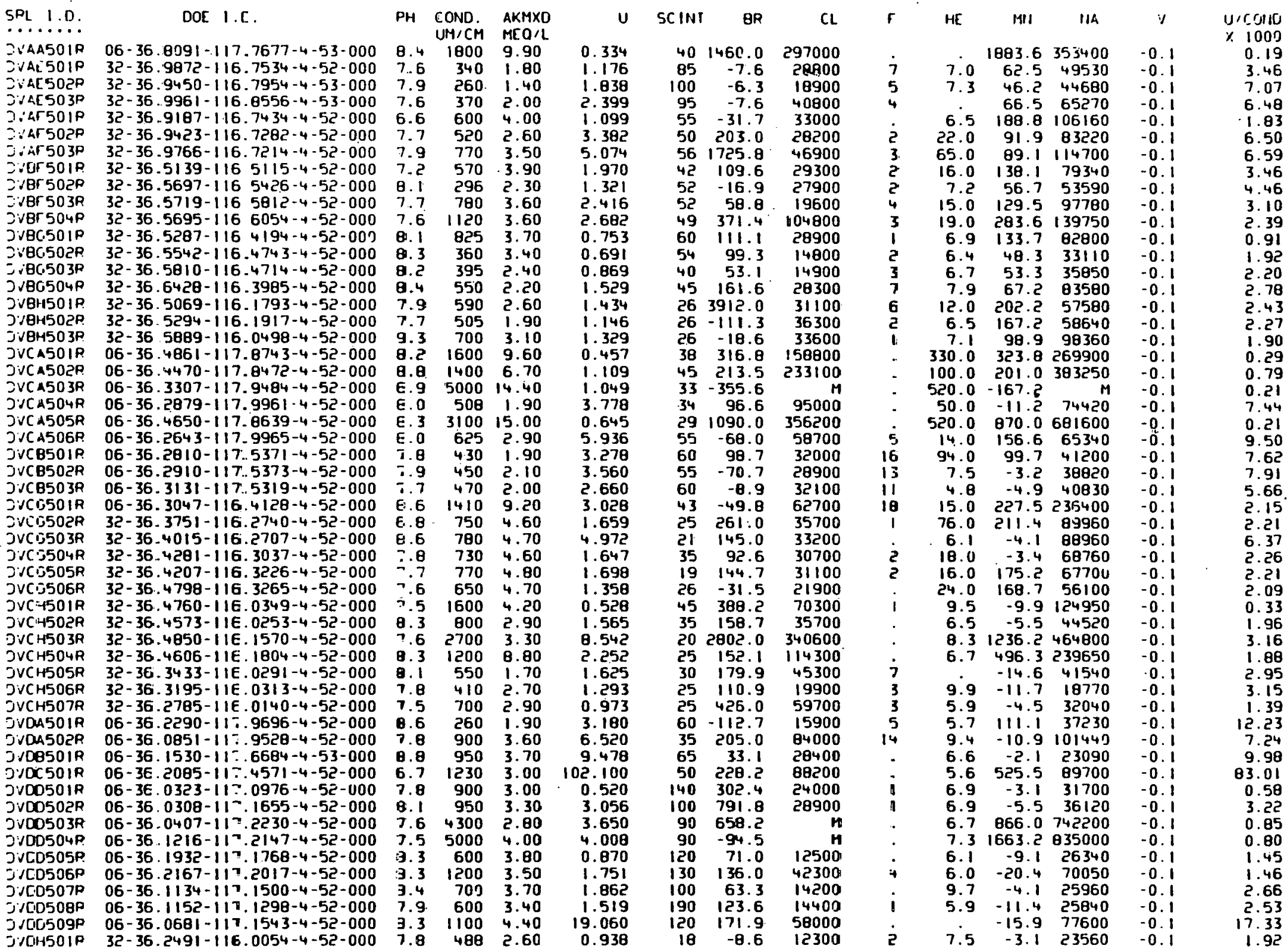



$U$ GP CL $T$ MN NA AND V ELEMENIAL CONCENTRAIIONS IN PPB. HE IN PPM IN ? CI AIR GAP ABOVE 300 CC HZO. SCINI IN CPS.

\begin{tabular}{|c|c|c|c|c|c|c|c|c|}
\hline$P L I D$ & Dot 1.0. & PH & $\begin{array}{l}\text { COND. } \\
\text { UM/CM }\end{array}$ & $\begin{array}{l}\text { AKMXO } \\
M E O / L\end{array}$ & $u$ & SCINI & BR & \\
\hline 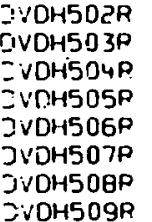 & $\begin{array}{l}32-36.2436-116.0511-4-52-000 \\
32-36.2436-116.0853-4-52-000 \\
32-36.2070-116.0230-4-52-000 \\
32-36.2059-116.0555-4-52-000 \\
32-36.2021-116.0863-4-52-000 \\
32-36.1710-116.0871-4-52-000 \\
32-36.236-116.1592-4-52-000 \\
06-36.0229-116.1544-4-52-000\end{array}$ & $\begin{array}{l}7.4 \\
7.6 \\
7.3 \\
7.5 \\
7.6 \\
7.7 \\
16.7 \\
1.0\end{array}$ & $\begin{array}{l}1300 \\
410 \\
980 \\
498 \\
447 \\
449 \\
361 \\
725\end{array}$ & $\begin{array}{l}1.80 \\
2.20 \\
2.00 \\
2.00 \\
2.60 \\
2.20 \\
2.10 \\
3.10\end{array}$ & $\begin{array}{l}1.259 \\
0.514 \\
3.270 \\
1.553 \\
1.024 \\
1.352 \\
1.349 \\
0.601\end{array}$ & $\begin{array}{l}26 \\
16 \\
20 \\
21 \\
24 \\
26 \\
33 \\
32\end{array}$ & $\begin{array}{r}-35.9 \\
69.0 \\
137.9 \\
88.6 \\
74.9 \\
97.1 \\
111.0 \\
6510.0\end{array}$ & $\begin{array}{r}23310 \\
1430 \\
4590 \\
2310 \\
1090\end{array}$ \\
\hline
\end{tabular}

CL
100
300
900
100
900
600
700

$\begin{array}{rrrrr}r & \text { HE } & \text { MN } & \text { MA } \\ & & & & \\ 2 & 12.0 & -16.0 & 77000 & -0.0 \\ 1 & 280.0 & -2.3 & 21650 & -0 \\ 2 & 5.4 & -12.3 & 48900 & - \\ 2 & 6.0 & -1.11 & 16590 & -0 \\ 2 & 7.1 & -0.3 & 17350 & -0 \\ 5 & 5.6 & -1.1 & 17550 & -0 \\ 4 & 130.0 & -7.2 & 26000 & -0 . \\ 2 & 7.9 & -8.7 & 76820 & -0\end{array}$

$\begin{array}{cr}v & u^{\prime} C 0110 \\ & \times 1000 \\ -0.1 & 0.97 \\ -0.1 & 1.25 \\ -0.1 & 3.34 \\ -0.1 & 3.12 \\ -0.1 & 2.29 \\ -0.1 & 3.01 \\ -0.1 & 3.74 \\ -0.1 & 0.83\end{array}$


Key data reported for stream sediment sites include:

- elemental analyses (in order of appearance in figures) for $U$, $\mathrm{Th}, \mathrm{Hf}, \mathrm{Al}, \mathrm{Ce}, \mathrm{Fe}, \mathrm{Mn}, \mathrm{Sc}, \mathrm{Na}, \mathrm{Ti}$, and $\mathrm{V}$

- analyses for the supplemental elements Dy, Eu, La, Lu, Sm, and $\mathrm{Yb}$

- sampling site descriptors (stream characteristics, vegetation, etc.) 
B-1 Areal Distribution of Uranium Concentrations in Stream Sediment

B-2 Areal Distribution of Thorium Concentrations in Stream Sediment

B-3 Areal Distribution of Hafnium Concentrations in Stream Sediment

B-4 Areal Distribution of Aluminum Concentrations in Stream Sediment

B-5 Areal Distribution of Cerium Concentrations in Stream Sediment

B-6 Areal Distribution of Iron Concentrations in Stream Sediment

B-7 Areal Distribution of Manganese Concentrations in Stream Sediment

B-8 Areal Distribution of Scandium Concentrations in Stream Sediment

B $=9$ Areal Distribution of Godium Concentrations in $3 t$ team Eediment

B-10 Areal Distribution of Titanium Concentrations in Stream Sediment

B 11 Areal Distribution of Vanadiun Cunedit $t$ aliums in Stream Sediment

Figures on Microfiche:

Log Histograms and Cumulative Frequency Flots for U, Th, $\mathrm{Hf}, \mathrm{Al}, \mathrm{Ce}, \mathrm{Fe}, \mathrm{Mn}, \mathrm{Sc}, \mathrm{Na}, \mathrm{Ti}$, and $\mathrm{V}$ for Stream Sediments. 
B-1 Key Field Measurements and Analytical Data - Sediment

B-2 Supplementary Field and Analytical Data - Sediment. See and Microfiche Cards: "Sediment Plots," "B-2" and "B-3". B-3 
TABLE B-1 -aBULATION OF KEY FIELD MEASUREMENIS AND ANALYTICAL DATA - SEDIMENTS-- DERTH VALLEY SHEET

SRL 1.0

DOE I.D.

PH COND. AXMXD
UM/CM $M E Q / L$

JVAA00ISI $06-36.7825-117.9711-4-61-000$ JVAA002S1 $06-30.8551-117.9480-4-59-000$ JVAA003SI $06-36.8758-117.9727-4-61-000$ JVAA004SI $06-36.8713-117.9318-4-59-000$ JVAA005SI $06-36.9132-117.9363-4-61-000$
JVAA00651 $06-36.9233-117.9816-4-61-000$ JVAA00751 06-36.9451-117.9293-4-59-000 JVAA008SI 06-36.9527-117.9751-4-59-000 JVAA009S1 06-36.9777-117.95-0-4-61-000 JVAAOIOSI 06-36.9817-1117.9268-4-61-000 JVAAOIISI 06-36.8106-117.9319-4-61-000 JVAAOi2Sl 06-36.7782-117.9346-4-61-000 JVAAOI 351 06-36.7701-117.84E1-4-59-000 JVAAOI4SI 06-36.7645-117.89J9-4-61-000 JVAAOISSI 06-36.8118-117.89.66-4-61-000 JVAAOIESI $06-36.8115-117.83=1-4-61-000$ JVAAOI7S! 06-36.8359-117.8418-4-61-000 JVAAOIBS $06-36.8419-117.88=6-4-61-000$ JVAAOI9SI 06-36.8700-117.89:3-4-61-000 JVAAOCOS $06-36.8820-117.84=0-4-59-000$ JVAAOCISI $06-36.9128-117.8331-4-59-000$ JVAADC2SI $06-36.9113-117.88=8-4-61-000$ JVAAOE3SI 06-36.9455-117.88+2-4-61-000 JVAAOCHSI 06-36.9563-117.845.0-4-59-000 JVAAOC6SI 06-36.9782-117.68+7-4-61-000 JVAA02751 06-36.9865-117. 7956-4-61-000 JVAA028SI 06-36.9470-117.7937-4-59-000 JVAA029S1 06-36.9122-117.79:0-4-61-000 JVAAO30SI 06-36.8736-117.7957-4-59-000 JVAA03ISI 06-36.8410-117.7957-4-59-000 JVAA032SI 06-36.8073-117.7947-4-61-000 JVAA033S1 06-36.7695-117.8013-4-59-000 JVAA034S1 06-36.7660-117.75 $31-4-61-000$ JVAA035SI 06-36.8091-117.76.77-4-59-000 JVAA036SI 06-36.9920-117.7511-4-61-000 JVAA037S1 06-36.8853-117.7618-4-59-000 JVAA038S1 06-36.9185-117.75:19-4-59-000 JVAA039SI 06-36.9530-117.75-33-4-59-000 JVABO01Si 06-36.9751-117.7239-4-61-000 JVAB002S1 06-36.9395-117.72:36-4-61-000 JVAB00351 06-36.9094-117.73=0-4-59-000 JVAB004SI 06-36.8697-117.7254-4-59-000 JVAB005SI 06-36.8389-117.72:7-4-61-000 JVAB0065I $06-36.8005-117.73=8-4-61-000$ JVAB0075I 06-36.7687-117.72-0-4-61-000 JVAB008SI 06-36.7761-117.6858-4-59-000 JVAB009SI 06-36.8138-117.6846-4-61-000 JVABOIOSI 06-36.8418-117.6757-4-61-000 JVABOIISI $06-36.0757-117.6919-4-61-000$ JVABOILSI 06-36.9099-117.6857-4-61-000 JVABO1451 06-36.9713-117.6319-4-59-000 JVAB0I5SI 06-36.9451-117.6363-4-61-000 JVABOI651 $06-36.9240-117.6492-4-61-000$ JVAB0I75I 06-36.8733-117.6392-4-59-000

$\begin{array}{rrr}U & 1 H & H F \\ \text { PPM } & \text { PPM } & \text { PPM } \\ & & \\ 4.8 & 19 & 13 \\ 5.7 & 35 & 21 \\ 4.8 & 23 & 16 \\ 5.2 & 23 & 9 \\ 2.3 & 12 & 4 \\ 3.2 & 9 & 7 \\ 4.5 & 19 & 15 \\ 4.0 & 10 & 7 \\ 4.2 & 16 & 9 \\ 3.9 & 20 & 9 \\ 5.9 & 22 & 12 \\ 6.4 & 30 & 20 \\ 8.2 & 43 & 22 \\ 4.4 & 14 & 14 \\ 10.8 & 35 & 22 \\ 3.9 & 17 & 0 \\ 3.0 & 14 & 6 \\ 5.1 & 24 & 13 \\ 3.1 & 13 & 6 \\ 2.9 & 8 & 3 \\ 5.4 & 2.1 & 14 \\ 3.1 & 12 & 0 \\ 5.8 & 31 & 13 \\ 5.4 & 24 & 17 \\ 4.5 & 20 & 11 \\ 3.6 & 10 & 6 \\ 4.8 & 21 & 10 \\ 3.3 & 17 & 11 \\ 4.1 & 16 & 10 \\ 5.0 & 21 & 19 \\ 5.0 & 26 & 10 \\ 3.7 & 15 & 10 \\ 3.3 & -4 & 2 \\ 5.0 & 27 & 10 \\ 1.9 & 8 & 0 \\ 4.4 & 16 & 0 \\ 3.7 & 17 & 8 \\ 3.4 & 9 & 7 \\ 4.1 & 14 & 14 \\ 3.7 & 13 & 8 \\ 5.3 & 24 & 19 \\ 4.6 & 15 & 12 \\ 4.4 & 19 & 12 \\ 11 . & 11 & M \\ 7.0 & 35 & 17 \\ 9.3 & 65 & 16 \\ 4.3 & 15 & 10 \\ 4.3 & 16 & 6 \\ 4.0 & 16 & 9 \\ 3.5 & 20 & 6 \\ 4.1 & 10 & 7 \\ 3.8 & 18 & 13 \\ 2.4 & 7 & 4 \\ 2.4 & 12 & 4 \\ 4.2 & 12 & 6 \\ & & \end{array}$

SCINT
CPS
50
40
5
5
10
30
20
30
20
30
50
50
50
10
50
35
30
35
25
40
40
30
35
40
30
35
30
35
30
30
40
20
30
30
25
25
25
30
30
40
45
40
30
30
50
40
25
30
15
30
40
30
20
20
50

\begin{tabular}{rr} 
PPM & $P P M$ \\
& \\
114 & 36500 \\
171 & 51900 \\
133 & 29600 \\
92 & 40700 \\
-20 & 23200 \\
66 & 26400 \\
112 & 34900 \\
31 & 21100 \\
86 & 35500 \\
117 & 21900 \\
166 & 65600 \\
139 & 64700 \\
220 & 91300 \\
123 & 80800 \\
170 & 99300 \\
-20 & 30700 \\
-20 & 30300 \\
95 & 39900 \\
78 & 27700 \\
49 & 22300 \\
95 & 39100 \\
93 & 26500 \\
180 & 46000 \\
124 & 46500 \\
117 & 39900 \\
66 & 20700 \\
129 & 40000 \\
115 & 37600 \\
137 & 35800 \\
118 & 45000 \\
149 & 48200 \\
108 & 44000 \\
98 & 30100 \\
115 & 44800 \\
55 & 22700 \\
-20 & 37500 \\
92 & 38400 \\
60 & 20500 \\
121 & 35400 \\
90 & 35000 \\
143 & 37300 \\
96 & 33000 \\
107 & 32900 \\
$M$ & 14 \\
138 & 36700 \\
140 & 46500 \\
118 & 37300 \\
109 & 40900 \\
101 & 35100 \\
105 & 30500 \\
56 & 19000 \\
104 & 35100 \\
56 & 23800 \\
74 & 28600 \\
62 & 22100 \\
& \\
\hline
\end{tabular}

$\begin{array}{rrr}\text { MN } & \text { NA } & \text { SC } \\ \text { PPM } & \text { PPM } & \text { PPM }\end{array}$

$\begin{array}{rr}\text { TI } & V \\ \text { PPM } & \text { PPM }\end{array}$

$\begin{array}{rrrrr}M & 22900 & 12.0 & M & M \\ 610 & 23200 & 12.0 & M & -10\end{array}$

$\begin{array}{lllll}2040 & 29600 & 8.4 & M & -30\end{array}$

$1800-100 \quad 9.2$

$\begin{array}{rrr}420 & 6600 & 7.8\end{array}$

$\begin{array}{lll}730 & 11200 & 5.5\end{array}$

$870 \quad 17600 \quad 11.0$

$\begin{array}{rrr}670 & 16500 & 7.2\end{array}$

$\begin{array}{rrr}-10 & 100 & 3.7\end{array}$

0301960010.9

820 52100 19.8

$\begin{array}{lll}20 & -100 & 26.6\end{array}$

$820 \quad 19000 \quad 12.6$

$390 \quad 18600 \quad 7.8$

$\begin{array}{rrr}490 & 23700 & 4.6 \\ 4 & 100 & 11.0\end{array}$

$450 \quad 11900 \quad 6.3$

$420 \quad 12300 \quad 6.4$

6602010011.3

$\begin{array}{rrr}20 & 100 & 7.6\end{array}$

$\begin{array}{lll}640 & 20200 & 0.3\end{array}$

$68018600 \quad 2.9$

78024500

$-30-100$

$58020100 \quad 6.6$

$\begin{array}{lll}380 & 17200 & 10.7\end{array}$

$\begin{array}{lll}690 & 24000 & 10.7\end{array}$

$\begin{array}{lll}-40 & -100 & 13.3\end{array}$

$670 \quad 19100 \quad 13.4$

1350 20700

$\begin{array}{rr}-40 & -100 \\ 1280 & 25500\end{array}$

$\begin{array}{lll}1280 & -100 & 8.5 \\ 5 & 500\end{array}$

$\begin{array}{rrr}1070 & -100 & 1.9\end{array}$

$\begin{array}{lll}M & -100 \quad 11.1\end{array}$

$\begin{array}{lll}1190 & 21900 & 5.6\end{array}$

$\begin{array}{crr}1530 & -100 & 2.4 \\ 70300 & 5.9\end{array}$

$\begin{array}{lll}70 & -100 & 11.0\end{array}$

$1206 \quad 1970011.1$

$M \quad-100 \quad 10.9$

M 234639.7

$1560 \quad 24800 \quad 6.2$

$1140 \quad 30200 \quad 8.8$

$M \quad 13900 \quad 11.2$

$\begin{array}{lrr}1040 & -100 \quad 5.8\end{array}$

$\begin{array}{lll}-40 & 21900 & 3.2\end{array}$

$1830-100 \quad 10.7$

$\begin{array}{rrr}1240 & 13100 & 5.6 \\ 1210 & 16900 & 3.7\end{array}$

$2400 \quad 40$

$M \quad 50$

$\begin{array}{rr}M & 0 \\ 5700 & 90\end{array}$

$4300 \quad 50$

$4100 \quad 130$

$6800 \quad 240$

$2800 \quad 170$

$\begin{array}{rr}M & 210 \\ 0500 & 260\end{array}$

$3100-10$

$\begin{array}{ll}M & 40 \\ M & M\end{array}$

$\begin{array}{lr}M & 20 \\ M & 0\end{array}$

$6400 \quad 110$

$9700 \quad 90$

$\begin{array}{rr}M & 70 \\ M & 200\end{array}$

$4500 \quad 120$

M 100

$\begin{array}{lr}M & 00 \\ M & -20\end{array}$

$M \quad 60$

$\begin{array}{cr}M & 110 \\ M & 90\end{array}$

$16200 \quad 100$

M 130

$\begin{array}{rr}M 00 & 50 \\ M & 80\end{array}$

$4900 \quad 60$

$M \quad 110$

$M$
$M$

$\begin{array}{cc}M & 60 \\ M & M\end{array}$

$\begin{array}{ll}M & M \\ M & M\end{array}$

$\begin{array}{lr}M & 90 \\ M & M\end{array}$

$M \quad 70$

$400 \quad M$

$\begin{array}{rr}M & 120 \\ 100 & 120\end{array}$

$3400 \quad 60$

$\begin{array}{rrrrr}M & -100 & 9.1 & M & 40\end{array}$ 
TABIL B-I TABULATION OF KEY FIELD MEASUREMENTS AND ANALYTICAL DATA - SEDIMENTS-- DEATH VALLEY SHEET

SRL I.D.

DOE I.D

JVABOIBSI $06-36.8392-117.6418-4-61-000$ JVABOISSI $06-36.8103-117.6569-4-59-000$ JVAE00151 32-36.9311-116.7723-4-59-000 JVAED025I $32-36.9432-116.7975-4-59-000$ JVAE0035I 32-36.9573-116.7875-4-59-000 JVAE00451 32-36.9851-116.7534-4-59-000 JVAED0551 32-36 9048-116. $3209-4-59-000$ JVAEOOSSI 32-36. 8910-116.8548-4-59-000 JVAE00751 32-36.9196-116.0606-4-59-000 JVAE008SI 32-36 9607-116. $9779-4-59-000$ JVAEO09SI 32-36.9949-116. $3504-4-59-000$ JVAEOIOS1 32-36.9日10-116.0192-4-59-000 JVAE01151 32-36 84104-116.8606-4-59-000 JVAEDIJS1 32-36. $0050-116.8622-4-59-000$ JVAE01351 32-36.7793-116.8394-4-59-000 JVAE01451 32-36.7713-116.0094-4-59-000 JVAE015SI 32-36. $3074-116.8154-4-59-000$ JVAEOISSI 32-36.8442-116.8227-4-59-000 JVAE01750 32-36.8691-116.7606-4-50-000 JVAE01851 32-36.8560-116.7584-4-59-000 JVAE01951 32-36.7933-116.7670-4-59-000 JVAE02051 32-36.7815-116.7885-4-59-000 JVAE02151 32-36.9126-116.7566-4-59-000 JVAFO0IS1 32-36.9209-116.7441-4-59-000 JVAFOOZSI 32-36.9405-116.7220-4-59-000 JVAF00351 32-36.9744-116.7237-4-59-000 JVAFOO4SI 32-36.9563-116. $3967-4-59-000$ JVAF00551 32-36.9672-116.6591-4-59-000 JVAFOOSS1 32-36.9689-116.6406-4-59-000 JVAF00751 32-36. JVAFOOSI 32-36. 8959-116.7135-4-59-000 JVAFO09S1 32-36.859-116.7135-4-59-000 JVAFOIOS1 32-36.0674-116.6455-4-59-000 JVAF01151 32-36.8468-116.6313-4-59-000 JVAFOIZSI 32 $36.0093-116.6031-4-59-000$ JVAF01351 32-36.7825-116.6119-4-59-000 JVAF01451 32-36.7582-116.6271-4-59-000 כVAF015S1 32-36.7751-116.6870-4-59-000 כVAF01651 32-36.0101-116.6906-4-59-000 JVAFOIRI 32-36.8101-116.6986-4-59-000 JVAFOIOS1 32-36.0080-116 7346-4-59-000 ว JVAFO20S1 32-36.77301-116.7244 -4 -59-000 JVAF02151 32-36.7506-116.5821-4-59-000 JVAF023S1 32-36.7537-116.5358-4-59-000 JVAF0251 32-36. JVAF02351 32-36.0407-116. JVAFO2 51 32-36.8707-116.54 JVAF JVAFC JVAF 32 1 32-36.9325-116.5902-4-59-000 JVAFOCOS 32-36.9325-116. JVAF 029S1 32-36.9194-116.6438-4-59-000 JVAF 031SI $32-36.9407-116.6388-4-59-000$
$\mathrm{PH}$ COND. COND. AKMXD
UM/CM MEO/L

$\begin{array}{rrr}\text { U } & \text { IH } & \text { HF } \\ \text { PPM } & \text { PPM } & \text { PPM } \\ 3.5 & 14 & 5 \\ 4.0 & 15 & 11 \\ 4.6 & 22 & 13 \\ 4.3 & -4 & 9 \\ 4.5 & -4 & 5 \\ 4.1 & 21 & 12 \\ 3.3 & 11 & 1 \\ 3.6 & 9 & 9 \\ 3.4 & -4 & 2 \\ 3.6 & 7 & 6 \\ 3.4 & 9 & 5 \\ 3.1 & 12 & 5 \\ 4.8 & 15 & 8 \\ 3.3 & -4 & 0 \\ 8.9 & 7 & 28 \\ 6.6 & 21 & 21 \\ M & M & M \\ 3.5 & M & 0 \\ M & M & M \\ 3.8 & 7 & 10 \\ 4.1 & 23 & 23 \\ 3.8 & -4 & 0 \\ 4.1 & 10 & 14 \\ 3.0 & M & 7 \\ 3.0 & M & 0 \\ M & M & M \\ 3.4 & 14 & 10 \\ 4.0 & 7 & 8 \\ 2.6 & -4 & 0 \\ 3.3 & 12 & 14 \\ 3.0 & -4 & 0 \\ 8.0 & 13 & 16 \\ 5.1 & 10 & 6 \\ 2.6 & -4 & 5 \\ 3.0 & -4 & 0 \\ 2.7 & -4 & 0 \\ 2.4 & 13 & 7 \\ 2.8 & 14 & 16 \\ 4.3 & -4 & 16 \\ 2.0 & -4 & -1 \\ 1.8 & 5 & 0 \\ 3.7 & 15 & 15 \\ 4.7 & 21 & 15 \\ 2.8 & 9 & 6 \\ 2.8 & 12 & 9 \\ 3.5 & 13 & 5 \\ 4.4 & 5 & 13 \\ 3.7 & 14 & 9 \\ 3.0 & 17 & 7 \\ 3.9 & -4 & 11 \\ 3.4 & 19 & 7 \\ 3.6 & 10 & 7 \\ 2.5 & M & 7 \\ 3.2 & 14 & 9 \\ 2.9 & -4 & 0 \\ & & \end{array}$

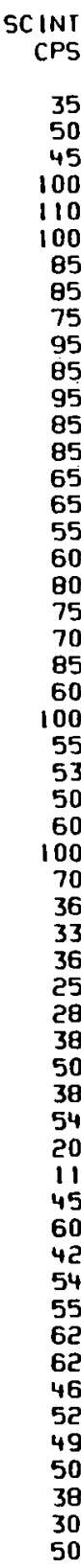

$\begin{array}{rr}C E & F E \\ P P M & P P M \\ & \\ 82 & 24390 \\ 89 & 34800 \\ 123 & 39300 \\ 37 & 6500 \\ 80 & 10600 \\ 155 & 25300 \\ 47 & 14400 \\ 48 & 25200 \\ M & M \\ 33 & 20300 \\ 55 & 14300 \\ 50 & 23600 \\ 69 & 28400 \\ -20 & 2500 \\ M & 13800 \\ 93 & 36100 \\ M & M \\ M & M \\ M & M \\ 55 & 13600 \\ 216 & 33400 \\ M & M \\ 54 & 22400 \\ M & M \\ M & M \\ M & M \\ 100 & 26300 \\ M & 16800 \\ 30 & 5900 \\ 98 & 22500 \\ M & M \\ 113 & 23900 \\ 50 & 19800 \\ M & 7400 \\ M & M \\ M & M \\ 67 & 17700 \\ M & 20500 \\ M & M \\ 22 & 6800 \\ 33 & 10300 \\ 114 & 27700 \\ 96 & 36900 \\ 49 & 26200 \\ 62 & 11300 \\ 72 & 7100 \\ 101 & 17700 \\ 69 & 20200 \\ 101 & 24200 \\ M & 9 \\ 102 & 27200 \\ 63 & 16200 \\ M & M \\ 93 & 22300 \\ 30 & 6200 \\ & \end{array}$

$\begin{array}{rrr}M N & N A & S C \\ \text { PPM } & P P M & \text { PPM } \\ & & \\ 440 & 16300 & 6.7 \\ 580 & 18100 & 10.4 \\ 1370 & -100 & 15.2 \\ 130 & 3100 & 4.8 \\ 280 & 11700 & 4.5 \\ 560 & 15600 & 3.6 \\ 270 & 13300 & 3.0 \\ 660 & 15200 & 5.5 \\ 300 & 8100 & -0.2 \\ 580 & 13300 & 1.0 \\ 420 & 10000 & 3.9 \\ 610 & 16300 & 6.2 \\ M & -100 & 6.1 \\ 210 & 5600 & 1.8 \\ 220 & 4000 & 7.9 \\ 720 & 13600 & 1.6 \\ M & M M & M \\ -90 & 93500 & -0.2 \\ M & M M & M \\ 250 & 5700 & 6.8 \\ 690 & 19300 & 7.3 \\ 550 & 17700 & 0.9 \\ 0 & 16000 & 7.0 \\ 370 & 82500 & 3.0 \\ M & 108100 & -0.5 \\ M & M M & M \\ 600 & 17600 & 7.1 \\ 670 & 12000 & 4.5 \\ 120 & 5800 & 1.6 \\ 280 & 13100 & 1.2 \\ 340 & 11600 & -0.1 \\ 310 & 10000 & 5.0 \\ 270 & 10500 & 5.8 \\ 80 & 2900 & 1.9 \\ 190 & 7900 & -0.1 \\ 340 & 15000 & -0.4 \\ 420 & 16300 & 3.4 \\ 330 & 12900 & 5.2 \\ 370 & 11100 & 0.1 \\ 110 & 4100 & 1.9 \\ 1180 & 4300 & 2.6 \\ 480 & 13000 & 6.5 \\ 550 & 15900 & 6.7 \\ 410 & 11700 & 9.2 \\ 190 & 7800 & 2.7 \\ 190 & 7100 & 3.2 \\ 280 & 9000 & 4.6 \\ 470 & 16900 & 6.2 \\ 390 & 14900 & 6.0 \\ 310 & 13900 & 3.1 \\ 490 & 17100 & 7.8 \\ 440 & 14800 & 4.3 \\ 240 & 7700 & 3.4 \\ 360 & 15800 & 6.2 \\ 130 & 4900 & 0.9\end{array}$

$\begin{array}{rr}I I & V \\ \text { PPM } & \text { PPM }\end{array}$ $M$
3800 $M \quad 90$ $500 \quad 10$ $2100 \quad 30$ $\begin{array}{ll}4300 & 60 \\ 1300 & 20\end{array}$ $2300 \quad 50$ $\begin{array}{rr}-250 & 20 \\ 2500 & 40\end{array}$ $\begin{array}{ll}2500 & 40 \\ 1800 & 30\end{array}$ $-400 \quad 40$
-250 $-250 M$ $1400 \quad 20$ 570090 710090 $5600 \quad 60$ $\begin{array}{lr}M & 40 \\ M & 0\end{array}$ $3000 \quad 100$ $M$
-400 $M \quad M$ $\begin{array}{rr}3500 & 40 \\ -300 & 50\end{array}$ $\begin{array}{rr}-300 & 50 \\ M & 0\end{array}$ $\begin{array}{ll}M & -10\end{array}$ 3800 $\begin{array}{rr}M & 100 \\ M & 90\end{array}$ $\begin{array}{lr}M & 90 \\ M & 0\end{array}$ $M$
$M$
-250 11600 M 40 $M \quad 0$ $5500 \quad 80$ 


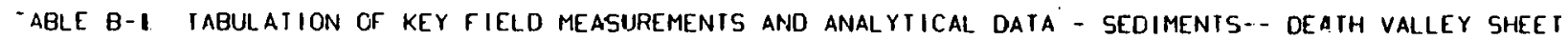

SRL I.D.

DOE 1.iD.

PH COND. AKMXO

$\begin{array}{rrr}U & I H & H F \\ \text { PPM } & \text { PPM } & \text { PPM } \\ & & \\ 6.0 & 19 & 9 \\ 3.8 & 15 & 0 \\ 1.9 & 11 & 5 \\ 4.0 & 14 & 11 \\ 3.5 & 8 & 6 \\ M & M & M \\ M & M & M \\ M & M & M \\ M & 1 M & M \\ M & M & M \\ 3.8 & 15 & 6 \\ 4.2 & 15 & 12 \\ 4.0 & 15 & 10 \\ 4.3 & 10 & 5 \\ 5.3 & 23 & 6 \\ 4.8 & 25 & 14 \\ 3.6 & 11 & 0 \\ 5.6 & 19 & 14 \\ 5.2 & 16 & 8 \\ 3.0 & 11 & 4 \\ 3.5 & 13 & 10 \\ 2.7 & 11 & 5 \\ 3.8 & 18 & 13 \\ 3.9 & 13 & 6 \\ 3.9 & 18 & 10 \\ 3.9 & 13 & 8 \\ 6.4 & 22 & 15 \\ 3.6 & 18 & 6 \\ 5.0 & 20 & 15 \\ 2.8 & 11 & 5 \\ 3.3 & 13 & 6 \\ 5.2 & 19 & 0 \\ 3.8 & 14 & 0 \\ 5.0 & 25 & 10 \\ 5.0 & 15 & 13 \\ 5.8 & 17 & 14 \\ 8.9 & 36 & 12 \\ 13.1 & 55 & 21 \\ 5.6 & 24 & 12 \\ 12.9 & 63 & 24 \\ 5.3 & 21 & 16 \\ 3.8 & 18 & 6 \\ 5.1 & 22 & 9 \\ 5.6 & 20 & 15 \\ 3.9 & 9 & 7 \\ M & M & M \\ M & M & M \\ M & M & M \\ M & M & M \\ 3.5 & 17 & 13 \\ 5.2 & 16 & 8 \\ 6.6 & 29 & 21 \\ 2.9 & 14 & 10 \\ 4.6 & 21 & 17 \\ 4.1 & 15 & 12 \\ & & \end{array}$

CE $\quad$ FE

64. 12000

$-20 \quad 14300$

$33 \quad 29100$

5123500

$06-36.5612-117-9901-4-61-000$

DVBA00351 06-36.5634-117.9444-4-61-000

JVBA005S1 06-36.5219-117.9901-4- -000

JVBA00651 06-36.5199-117.9378-4- -000

JVBA00751 06-36.5252-117.8943-4-59-000 JVBA008S1 06-36.5528-117:8925-4-61-000 JVBA00951 06-36.5551-117.8562-4-61-000 JVBAOIOS1 $06-36.5158-117.8549-4-61-000$ JVBAOIS1 06-36.6307-117. $9919-4-61-000$ JVBA01351 06-36.7013-117.9887-4-61-000 JVBA014SI 06-36.7423-117.9923-4-59-000 JVBA015S1 $06-36.7315-117.9234-4-61-000$ JVEA016S1 06-36.6991-117.8874-4-61-000 JVBAOIS1 $06-36.6600-117.8549-4-61-000$ JVBA0I9S1 $06-36.6311-117.7975-4-61-000$ JVBA020S $06-36.5542-117.8086-4-59-000$ JVBA022SI $06-36.6024-117.8^{4}+87-4-59-000$ JVBA02351 06-36.5923-117.8855-4-59-000

JVBA02551 $06-36.6319-117.0930-4-59-000$ JVBA026S1 06-36.6294-117.8302-4-59-000 JVBA0C7SI 06-36.6967-117.8468-4-59-000 JVAC2BS $06-36.7296-117.8465-4-61-000$ JVA029S1 06-36.7308-117.8079-4-59-000 J JVA JVA032S1 06-36.6998-117.7686-4-61-000 JVBA3351 06-36.7300-117.7692-4-59-000 JVBO0151 06-36.7279-117.7245-4-61-000 JV8B0251 06-36.6967-117.7284-4-61-000 (3) JV800451 06-36.6354-117.7231-4-61-000 JVBD05S $06-36.6275-117.6840-4-61-000$ JVBB00651 06-36.6648-117.6879-4-61-000 Jv8800751 06-36.6978-117.6777-4-61-000 JVBBo085i 06-36.7276-117.6758-4-61-000 JVBB00951 06-36.7262-117.6365-4-59-000 JVBBolosi $06-36.6954-1176461-4-59-000$ JVBOIISI 06-36.6544-117.6450-4-61-000 JVBBolटs1 06-36.6251-117 5449-4-61-000 JVBB01351 06-36.6277-117 5022-4-61-000 JVBBOI4S1 06-36.6272-117 5483-4-61-000 3v88015S1 06-36.5988-117 5461-4-59-000 JVBBOI651 06-36.5941-117 5177-4-61-000 JVBBnIf5! 06-36.5634-117 5184-4-61-000 JVBBolesi 06-36.5428-117 5442-4-61-000 JVBBOISSI 06-36.5196-117 5576-4-59-000 JV8B020S1 $06-36.5583-1175961-4-59-000$$$
\text { M }
$$$$
M
$$$$
\begin{array}{r}
M \\
69
\end{array}
$$

25100

9128600

33100

9437400

15035900

8125310

iil 52500

$-20 \quad 32900$

100 67900

37900

459010

0075

19742110

11 25300

7733100

7) 33100

8028100

$63 \quad 30200$

9728060

$-20 \quad 33900$

130

8935360

8935360

4767700

14767700

$1671064 C 0$

11641780

10936460

94 376C0

$123454 \mathrm{c0}$

$51 \quad 17700$

$M \quad M$

$M \quad M$

02 34200

日2 39100

13772700

$84 \quad 30300$

B7 41500

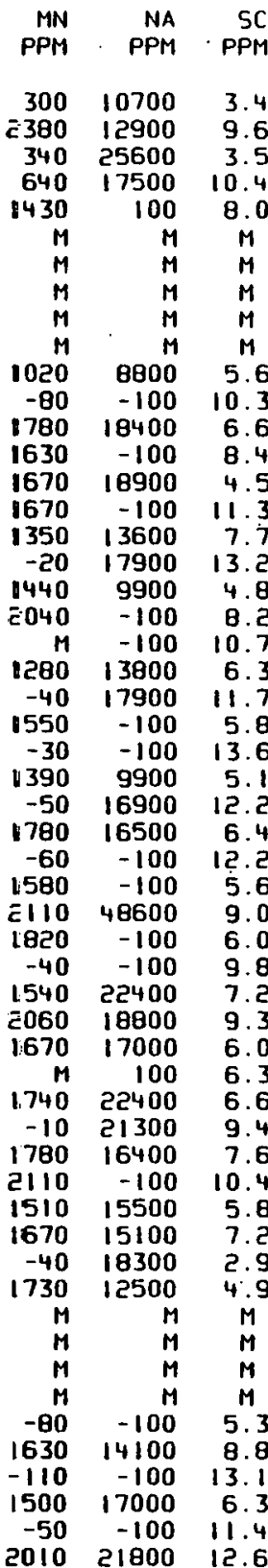

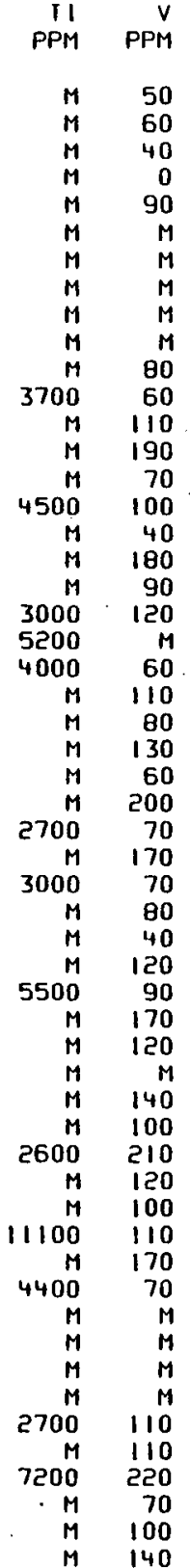


'ABLE B-1 IABULATION OF KEY FIELD MEASUREMENTS AND ANALYTICAL DATA - SEDIMENTS- DEATH VALLEY SHEET

SRL I.D.

DOE I.D.

JV8B025S1 $06-36.5169-117.6396-4-61-000$ JVB8023SI 06-36.5478-117.6502-4-61-000 JVBB02451 06-36.5519-117.6848-4-61-000 JVBBoc5si 06-36. $5247-117.6880-4-61-000$ JVBB0ट651 06-36.5234-117.74|9-4-61-000 JVB802751 06-36.5541-117. $7260-4-61-000$ JVB8028si 06-36.5944-117.7309-4-59-000 JVeB029S1 06-36.5930-117.6792-4-59-000 JVB8030SI 06-36.5969-117.6448-4-61-000 JVBB03151 06-36.5899-117.5993-4-61-000 JVBE 00ISI $32-36.7258-116.7585-4-59-000$ JVBE002S1 32-36.7423-116.8017-4-59-000 JVEE 003S1 32-36.6982-116.7587-4-59-000 JVBF 001S1 32-36.74ट0-116.6477-4-59-000 JVBF 00251 32-36.7200-116.6118-4-59-000 JVBF 003S1 32-36.7053-116.5878-4-59-000 JVBr 004S1 32-36.6944-116.5679-4-59-000 JVBr 005SI 32-36.7169-116.5524-4-59-000 JVBF 006S) 32-36.6792-116.5381-4-59-000 JVBF 00751 32-36.6866-116.51ट3-4-59-000 JVEF 008SI 32-36.6612-116.5502-4-59-000 JVBF 009SI 32-36.6303-116.5424-4-59-000 JVBF 0IOSI 32-36.6337-116.5172-4-59-000 JVBF 0IISI $32-36.7203-116.6741-4-59-000$ JVBF0I2SI $32-36.6933-116.6877-4-59-000$ JVBF 01351 32-36.7283-116.7306-4-59-000 JVBF 014S1 32-36.6960-116.7225-4-59-000 JVBF 015S1 32-36.6654-116.7289-4-59-000 JVBF 0l6si 32-36.6518-116.6839-4-59-000 JVBF 017S! $32-36.6274-116.6886-4-59-000$ JVBr 0IBSI 32-36.6125-116.6568-4-59-000 JVBF 0I9SI $32-36.5634-116.5069-4-59-000$ JVBF 020S1 32-36.5271-116.5068-4-59-000 JVBF 02151 32-36.5980-116.5071-4-59-000 JVBF 02251 32-36.5987-116.5414-4-59-000 JVBr 0e3si $32-36.5560-116.5433-4-59-000$ JVBF 024S1 $32-36.5693-11.6 .5784-4-59-000$ JVBF 0essi $32-36.5710-116.6046-4-59-000$ JVBF 026S1 32-36.6954-116.6520-4-59-000 JVBF 027SI 32-36.6697-116.6208-4-59-000 JVBF 02851 $32-36.6567-116.6133-4-59-000$ JVBF $0295132-36.6288-116.5996-4-59-000$ JVBF 030S1 32-36.5096-116.6274-4-59-000 JVer03151 32-36.5215-116.5540-4-59-000 JVBGO0151 32-36.5261-116.4201-4-59-000 JVBG002S1 32-36.5250-116.4587-4-59-000 JVBG003SI $32-36.5247-116.3830-4-59-000$ JVBG004SI 32-36.5564-116.3395-4-59-000 JVBC005S1 32-36.5849-116.3252-4-59-000 JVBG00651 $32-36.5671-116.3025-4-59-000$ JVBG007S1 32-36.5517-116.2627-4-59-000 JVBG008S1 $32-36.5338-116.2721-4-59-000$ JVBG009SI 32-36.5091-116.2980-4-59-000 JVBG010S1 32-36.5303-116.3599-4-59-000 JVBG011SI 32-36.5430-116.4025-4-59-000
PH COND. AKMXO UM/CM MEQ/L

$\begin{array}{rr}U & 1 H \\ P P M & P P M \\ & \\ 4.7 & 25 \\ 3.7 & 13 \\ 3.5 & 9 \\ 3.1 & 11 \\ 3.9 & 14 \\ 3.7 & 15 \\ 5.6 & 18 \\ 3.7 & 16 \\ 5.0 & 27 \\ 5.4 & 21 \\ 3.0 & -4 \\ 2.6 & 12 \\ 8.3 & 32 \\ 3.1 & 16 \\ 3.2 & -4 \\ 3.5 & -4 \\ 3.1 & 8 \\ 3.5 & 13 \\ 3.2 & -4 \\ 3.4 & 9 \\ 3.4 & -4 \\ 3.5 & 6 \\ 3.6 & 18 \\ 3.7 & 13 \\ 3.6 & 15 \\ 3.6 & M \\ 2.9 & M \\ 4.9 & 16 \\ 3.7 & 10 \\ 5.1 & 10 \\ 4.5 & -4 \\ 3.2 & M \\ M & M \\ M & M \\ M & M \\ M & M \\ 4.1 & 9 \\ 4.4 & -4 \\ 3.4 & -4 \\ 3.6 & 9 \\ 3.5 & 9 \\ 4.3 & -4 \\ 3.7 & -4 \\ 4.3 & -4 \\ 3.9 & 12 \\ 3.0 & 14 \\ 3.2 & 9 \\ 2.9 & -4 \\ 2.9 & 9 \\ 2.8 & 12 \\ 3.9 & M \\ 3.0 & -4 \\ 3.1 & M \\ 3.3 & 15 \\ 2.7 & 12 \\ 3.3 & 13 \\ & \\ 3 . & \end{array}$

HF
PPM

CPS
SCINT

16
5
6
4
9
9
15
12
13
13
4
6
35
8
0
12
7
12
5
9
4
10
3
9
11
2
-1
15
10
16
5
14
$M$
$M$
$M$
$M$
19
8
6
12
6
12
8
14
13
9
8
8
18
12
15
3
15
19
14
10
PP

50
45
30
24
30
30
35
40
50
50
60
55
45
50
55
55
60
60
55
50
65
70
60
70
65
70
50
50
60
60
50
48
60
48
49
50
58
49
75
55
60
60
55
60
60
58
60
46
46
44
43
45
42
36
40

$\begin{array}{rrr}M N & N A & 5 \\ \text { PPM } & \text { PPM } & \text { PPM }\end{array}$

$\begin{array}{lll}M & -100 & 13.1\end{array}$

$\begin{array}{rrr}1690-100 & 8.5\end{array}$

$1930 \quad-100 \quad 5.6$

$1440 \quad 10400 \quad 5.4$

$\begin{array}{lll}1380 & 13300 & 9.3\end{array}$

$1890-100 \quad 10.8$

$\begin{array}{rrr}M & -100 & 2.8\end{array}$

$\begin{array}{lll}1890 & 19600 & 13.4\end{array}$

$\begin{array}{rrr}220 & 6200 & 3.0\end{array}$

$53015000 \quad 4.6$

$610 \quad 10700 \quad 13.0$

$290 \quad 11300$

$290 \quad 8700$

$480 \quad 15700 \quad 3.2$

$470 \quad 17800$

4500

5400

$550 \quad 14000$

$580 \quad 15700$

$\begin{array}{ccc}-50 & 89800 & -0.4\end{array}$

M 76300

1700

50010800

3007900

$\begin{array}{ll}160 & 3900 \\ 250 & 4800\end{array}$

3900
4000

0
200

200
330

0 
rable B-I IABULATION OF KEY FIELD MEASUREMENTS ANU ANALYTICAL DATA - SEOIMENTS-- DEATH VALLEY SHEET

SRL 1.0.

DOE I.D

JVBG0I2SI $32-36.5462-116.4304-4-59-000$ JVBG0I3SI 32-36.5569-116.4718-4-59-000 JVBG01451 $32-36.5827-116.4727-4-59-000$ JVBG01551 32-36.6154-116.4949-4-59-000 JVBG0I6SI $32-36.5858-116.4327-4-59-000$ วVBG0175I 32-36.5912-116.4051-4-59-000 JVBG0I8SI 32-36.6278-116.4044-4. $39-000$ JVBG019S1 32-36.6278-116.4429-4-59-000 JVBG0ว05। $32-36.6566-116.4375-4-59-000$ JVBG02ISI 32-36.6790-116.4850-4-59-000 JVBG0235! 32-36.6585-116.4729-4-59-000 JVBG0235I $32-36.6032-116.2552-4-59-000$ JVBG0245I $32-36.6633-116.4018-4-59-000$ JVBG02451 $32-36.6633-116.4018-4-59-000$ JVBG025S1 $32-36.6331-116.3427-4-59-000$ JVBO2651 32-36.6226-116.3014-4-59-000 JVBGO27S1 $32-36.6111-116.2722-4-59-000$ JVBHOD2SI $32-36.6231-116.2290-4-59-000$ 3 VBH00351 32-36.6719-116.2031-4-59-000 כVBH00451 32-36.5917-116.2287-4-59-000 JVBH00551 32-36.5749-116. วVBHOOSS1 32-36.5177-116.1390-4-59-000 วV8H00751 32-36.5110-116.1726-4-59-000 วV8H0051 32-36.5516-116.1469-4-59-000 JVBH0095 32-36.5452-116.1790-4-59-000 כVBHDIOS1 32-36.5204-116. JVBHDIISI 32-36.5536-116.2196-4-59-000 כV8401251 04-36.5602-116.0990-4-59-000 วV8401351 32-36.5080-116.0497-4-59-000 วV8401451 32-36.5942-116.0089-4-59-000 गVBH01551 32-36.5234-116.1079-4-59-000 गVBHDISS1 32-36.5234-116.1079-4-59-000 3 J日H1) JVCAODISI 06-36.4942-117.0766-4-59-000 JVCAODISI 06-36.495-117. JVCAOD351 06-36.4743-117.8100-4-59-000 JVCAOO4S1 06-36.4752-117. JVCA00551 06-36.449日-117. JVCAOOSS1 06-36.4516-117.8110-4-59-000 JVCA005) 06-36.4516-117.8110-4 $59-000$ JVCA00051 06-36.4086-117.0467-4-59-000 JVCA009Si 06-30.3791-117.8817-4-59-000 JVAOIOSI 06-36.3534-117.9070-4-59-000 JVCAOIIS1 06-36.3347-117.9340-4-59-000 JVCA012S1 06-36.3178-117.9510-4-59-000 JVCAOI351 06-36.3035-117.9810-4-59-000 JVCAOI4S1 06-36. $4115-117.8102-4-59-000$ JVCA0I5SI 06-36. $3757-117.8029-4-59-000$ JVCAOISI 06-36.3757-117.8029-4-59-000 JVCAOI7S1 05-36. $3391-117.7621-4-59-000$ JVCAOITS1 06-36. 3391-117. JVCAOISI 06-36. 3059-117.9055-4 JVCAOCOS1 06-35.2782-117.9820-4 JVCADOSI 06-36.2780-117.9410-4-59-000 JVCAO2ISI $06-36.2703-117.9091-4-59-000$
JVCA022SI $06-36.3694-117.8552-4-59-000$

\begin{tabular}{|c|c|c|c|c|c|}
\hline & $\begin{array}{l}\text { COND. } \\
\text { UM/CM }\end{array}$ & $\begin{array}{l}\text { AKMXD } \\
\text { MEO'L }\end{array}$ & $\begin{array}{r}U \\
\text { PPM }\end{array}$ & $\begin{array}{r}\text { IH } \\
\text { PPM }\end{array}$ & $\begin{array}{c}\text { HF } \\
\text { PPM }\end{array}$ \\
\hline & . & . & 3.9 & 16 & 10 \\
\hline & . & . & 3.3 & $M$ & 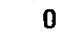 \\
\hline & . & . & 3.4 & -4 & 0 \\
\hline & . & . & 3.7 & 22 & 20 \\
\hline & . & . & 3.3 & 16 & 14 \\
\hline & . & . & 3.1 & 140 & \\
\hline & . & . & 2.9 & -4 & 2 \\
\hline & . & . & 3.3 & -4 & 11 \\
\hline & . & . & 3.8 & 21 & 18 \\
\hline & . & . & 2.9 & 10 & 6 \\
\hline & . & . & 3.4 & 15 & 13 \\
\hline & . & . & 3.2 & 10 & 15 \\
\hline & . & . & 3.0 & -4 & \\
\hline & . & . & 3.0 & 11 & 13 \\
\hline & . & . & 2.9 & 15 & 13 \\
\hline & . & . & 3.1 & 16 & 11 \\
\hline & . & . & 2.7 & 13 & 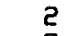 \\
\hline & . & . & 2.8 & -4 & \\
\hline & . & . & 2.4 & 110 & \\
\hline & . & . & 2.7 & 7 & 11 \\
\hline & . & . & 3.0 & 8 & 10 \\
\hline & . & $\cdot$ & 2.7 & 6 & \\
\hline & . & . & 2.8 & 11 & 16 \\
\hline & . & . & 3.5 & 11 & 15 \\
\hline & . & . & 3.0 & 11 & 11 \\
\hline & . & . & 2.7 & -4 & 10 \\
\hline & . & . & 3.0 & 25 & 17 \\
\hline & . & . & 2.6 & a & \\
\hline & . & $\cdot$ & 2.7 & 12 & 10 \\
\hline & . & . & 3.6 & 14 & 14 \\
\hline & . & . & 3.5 & 12 & 10 \\
\hline & . & · & 2.1 & $M$ & \\
\hline & . & . & 2.3 & 152 & \\
\hline & . & . & 4.7 & 14 & 10 \\
\hline & . & . & 3.2 & 8 & $\therefore$ \\
\hline & . & • & 3.0 & 14 & 10 \\
\hline & . & . & 5.0 & 6 & \\
\hline & . & . & 4.1 & $M$ & \\
\hline & - & · & 4.1 & -4 & \\
\hline & . & . & 3.1 & 6 & . \\
\hline & - & - & 4.3 & 9 & 11 \\
\hline & . & 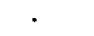 & 6.2 & 22 & 20 \\
\hline & - & . & 5.6 & 7 & 10 \\
\hline & · & . & 4.3 & $M$ & \\
\hline & - & . & 5.6 & $\cdot 9$ & 1 \\
\hline & - & $\cdot$ & 5.0 & 9 & \\
\hline & - & . & 5.6 & 14 & 1 \\
\hline & . & . & 4.6 & 18 & \\
\hline & . & 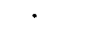 & 7.5 & -4 & 26 \\
\hline & & . & 5.1 & 7 & \\
\hline & - & - & 8.6 & 12 & 16 \\
\hline & . & & 4.1 & -4 & \\
\hline & - & . & 4.8 & $M$ & \\
\hline & & 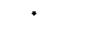 & 25.5 & 11 & 14 \\
\hline & . & 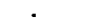 & 5.9 & 22 & \\
\hline
\end{tabular}

CE $\quad$ PPM

$\begin{array}{rr}159 & 25200 \\ M & M \\ M & 11100 \\ 179 & 29600 \\ 107 & 24500 \\ -20 & 7000 \\ -20 & 10100 \\ 27 & 6200 \\ 107 & 31000 \\ 113 & 18900 \\ 117 & 21700 \\ 43 & 21200 \\ 30 & 7400 \\ 74 & 16100 \\ 130 & 28100 \\ 108 & 28000 \\ 91 & 19900 \\ M & M \\ M & 9200 \\ M & M \\ 26 & 15100 \\ M & 10300 \\ 89 & 23900 \\ 95 & 28700 \\ 24 & 13000 \\ M & M \\ 71 & 21800 \\ 37 & 14900 \\ 101 & 29900 \\ 100 & 28000 \\ 87 & 30800 \\ M & M \\ 53 & 15300 \\ 52 & 28100 \\ 50 & 16900 \\ -20 & 35200 \\ 38 & 19000 \\ M & M \\ 26 & 15100 \\ 25 & 17100 \\ 60 & 23500 \\ 82 & 30800 \\ 37 & 15700 \\ M & M \\ 36 & 18900 \\ 66 & 15500 \\ 101 & 31700 \\ 78 & 24600 \\ M & M \\ 45 & 10500 \\ M & 45300 \\ -20 & 2300 \\ M & M \\ 56 & 10900 \\ 76 & +1100 \\ & \end{array}$

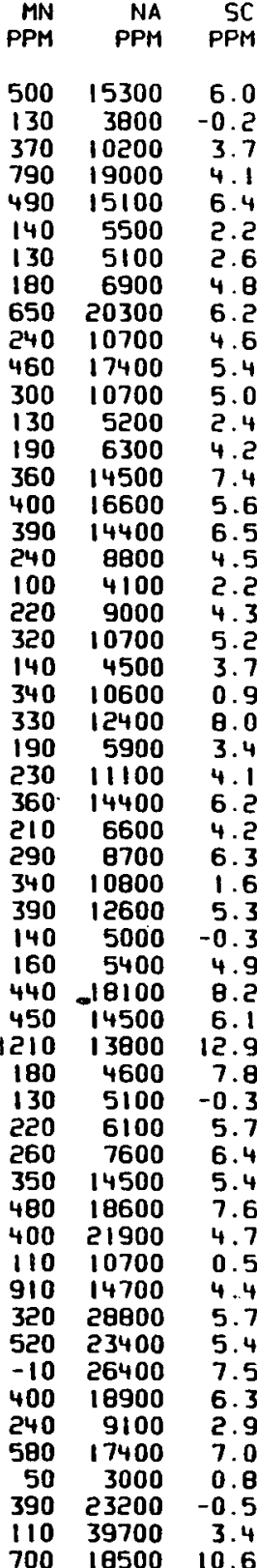

PPM PPM

$2800 \quad 40$

$500 \quad 10$

$4500 \quad 30$

$2500 \quad 40$

$M \quad 60$

$M \quad 60$

$4500 \quad 100$

$5000 \quad 50$

M 0

60

$1800 \quad 0$

$M \quad 70$

$\begin{array}{ll}M & 60 \\ M & 70\end{array}$

$M$
6200

6200

$10600 \quad 60$

$\begin{array}{ll}M & 90 \\ M & 80\end{array}$

$M \quad 60$

$M \quad 0$

$\begin{array}{ll}M & 50 \\ M & 60\end{array}$

$3000 \quad 30$

$M \quad 30$

110

$M \quad 40$

$3900 \quad 40$

$\begin{array}{ll}M & 130 \\ M & 40\end{array}$

$6900 \quad 120$

$M \quad 120$

$M \quad 140$

$\begin{array}{rr}M & 70 \\ M & 100\end{array}$

$4700 \quad 100$

$2300 \quad 30$

$M \quad 40$

$\begin{array}{rr}M & 60 \\ M & 130\end{array}$

$\begin{array}{rr}M & 120 \\ 9800 & 100\end{array}$

$M \quad 0$

$5800 \quad 100$

-250
2500

2500

$4300 \quad 90$ 
: ABLE B-I TABULATION OF KE" FIELD MEASUREMENTS AND ANALYIICAL DATA - SEDIMENIS-- DEATH VALLEY SHEET

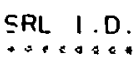

DOE I.D.

JVCA02351 06-36.3512-117.8349-4-59-000 JVCA0Z4S1 06-36.3385-117.8116-4-59-000 ZVCA025S1 $06-36 \cdot 3081-117.7932-4-59-000$ JVCA026SI $06-36 \cdot 3054-117.7672-4-59-000$ JVCA027S1 06-36.2700-117.7653-4-59-000 JVCB001S1 06-36.3343-117.7365-4-59-000 JVCB002S1 06-36.3242-117.6953-4-59-000 JVCB00351 $06-36.3151-117.6750-4-59-000$ JVCB004S1 06-36.3104-117.6494-4-59-000 JVC800551 06-36.2700-117.5870-4-59-000 JVCB00651 06-36.2815-117.5358-4-59-000 JVCB00751 06-36.3129-117.5319-4-59-000 2VCB008S1 06-36.2977-117.5193-4-59-000 JVCB0095i 06-36.3272-117.5130-4-59-000 JVCB010S1 06-36.3579-117.5275-4-59-000

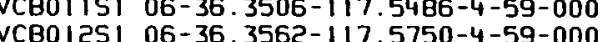
JVCB01351 06-36.3797-117.5942-4-59-000 JVCB014S1 06-36.3776-117.6299-4-59-000 JVCB0ISSI 06-36.4106-117.6341-4-59-000 JVCB01651 06-36.4099-117.6670-4-59-000 JVCB017S1 06-36.3756-117.6762-4-59-000 JVCB018S1 06-36.3066-117.6146-4-59-000 JVCB0I9SI 06-36.3240-117.5974-4-59-000

.

PH COND. AKMXD

$\begin{array}{rrr}\text { U } & \text { IH } & \text { HF } \\ \text { PPM } & \text { PPM } & \text { PPM } \\ 5.8 & -4 & 4 \\ 4.8 & 7 & 4 \\ 4.6 & 12 & 7 \\ 4.4 & 15 & 10 \\ 3.5 & 5 & 6 \\ 4.8 & 23 & 17 \\ 5.0 & 18 & 10 \\ 5.4 & 11 & 4 \\ 3.5 & -4 & 7 \\ 5.4 & 17 & 11 \\ 3.9 & 17 & 9 \\ 6.6 & 17 & 11 \\ 4.4 & 13 & 8 \\ 4.6 & 7 & 4 \\ 4.1 & 11 & 6 \\ 3.8 & 14 & 12 \\ 4.5 & 18 & 10 \\ 3.9 & -4 & 0 \\ 4.5 & 13 & 10 \\ 5.4 & -4 & 11 \\ 6.1 & 14 & 16 \\ 5.6 & -4 & 15 \\ 3.6 & 9 & 8 \\ 4.0 & -4 & 7 \\ 4.9 & -4 & 17 \\ 5.0 & 21 & 13 \\ 4.5 & 10 & 10 \\ 4.7 & 10 & 13 \\ 3.6 & -4 & 2 \\ 3.9 & 17 & 11 \\ 5.5 & 20 & 12 \\ 4.2 & 8 & 0 \\ 4.2 & 16 & 13 \\ 5.5 & 25 & 23 \\ 5.0 & 8 & 11 \\ 0.7 & M & 0 \\ 4.5 & 6 & 5 \\ 3.7 & 10 & 11 \\ 3.2 & 10 & 9 \\ 2.7 & 10 & 5 \\ 1.2 & -4 & 0 \\ 3.9 & -4 & 8 \\ 4.5 & 18 & 10 \\ 2.5 & -4 & 3 \\ 3.5 & 14 & 13 \\ 5.9 & 18 & 13 \\ 6.1 & 11 & 22 \\ 6.2 & 8 & 13 \\ 4.4 & 6 & 11 \\ 5.1 & 19 & 11 \\ 3.1 & 5 & 0 \\ 2.2 & -4 & 4 \\ 4.1 & 8 & 8 \\ 2.9 & -4 & 3 \\ 3.3 & 9 & 8\end{array}$

SCINT

CPS PPM FE

$\begin{array}{crr}M N & N A & 5 C \\ \text { PPM } & \text { PPM } & \end{array}$

PPM PPM

$\begin{array}{rrr}100 & 29 & 40500 \\ 55 & -20 & 17300\end{array}$

$\begin{array}{rrr}55 & -20 & 17300 \\ 55 & 53 & 21500 \\ 42 & -20 & 24400\end{array}$

49 M 18400

$\begin{array}{lll}60 & 94 & 39300\end{array}$

$55 \quad 36 \quad 14100$

75

$92 \quad 42700$

$112 \quad 39300$

$\begin{array}{ll}49 & 23000 \\ 63 & 34200\end{array}$

21 14400

4726000

$134 \quad 36000$

$\begin{array}{cr}M & M \\ 46 & 30200\end{array}$

$\begin{array}{rr}M & M \\ 68 & 24200\end{array}$

$M \quad M$

$M$

$M$

$\begin{array}{cr}M & M \\ 94 & 45200\end{array}$

$44 \quad 22200$

5329100

M 3900

$\begin{array}{ll}73 & 45300 \\ M & 19900\end{array}$

M 19900

$103 \quad 42100$

$107 \quad 46700$

45
$M$ JVCB030S1 06-36.4760-117.6875-4-59-000 JVCB032S1 $06-36.4182-117.7219-4-59-000$ JVCC001S1 06-36.3423-117.3887-4-59-000 JVCC002S1 06-36.3734-117.3929-4-59-000 JvCc03S1 06-36.4128-117.4066-4-59-000 JvCC005S1 06-36.3444-117.3521-4-59-000 วVCCO06S1 06-36.3470-117.3115-4-59-000 JVCC00751 06-36.3629-117.2887-4-59-000 JVCC008S1 06-36.4008-117.2806-4-59-000 JVCCOIOS1 $06-36 \cdot 3403-117.4232-4-59-000$ JVCCOIISI $06-36.3002-117.3904-4-59-000$ JVCCOIZS1 06-36.2646-117.3587-4-59-000 3VCCOI351 06-36.2955-117.4232-4-59-000 JVCCOI4S1 06-36.2667-117.4256-4-59-000 JVCC0I6SI 06-36.2586-117-3028-4-59-000 JVCC01751 $04-36.3892-117.3978-4-59-000$ JVCF001SI 06-36.4867-116.5373-4-59-000

$4700 \quad 180$

$1000 \quad 20$

$-400 \quad 80$

$-250 \quad 50$

2600
4000
1000

100020

410070

$2800 \quad 60$

$3400 \quad 100$

$\begin{array}{ll}3400 & 100 \\ 4600 & 150\end{array}$

80020

3000
$3700 \cdot 70$

$\begin{array}{rr}37000 & 100\end{array}$

$2200 \quad 40$

$4000 \quad 120$

2700

$\begin{array}{ll}2700 & 50 \\ -250 & 10\end{array}$

$\begin{array}{rr}2900 & 70 \\ -300 & 80\end{array}$

-300
8900

$3700 \quad 70$

$5100 \quad 80$

$3100 \quad 80$

3600770

$5500 \quad 110$

$1600 \quad 40$

5000
10300

$3100 \quad 60$

$400 \quad 20$

$1000 \quad 20$
$-250 \quad 70$

3000

\begin{tabular}{ll}
3000 & 80 \\
\hline & 60
\end{tabular}

550
-250

3800

$\begin{array}{rr}3800 & 80 \\ -300 & 110\end{array}$

$-400 \quad 100$

$4000 \quad 80$

$5500 \quad 110$

$1100 \quad 40$

$2700 \quad 60$

1700
4100

400
900

$\begin{array}{ll}500 & 10 \\ 900 & 30\end{array}$

4700

$-400 \quad 120$ 
- ABLE B-1 IABULATION OF KEY FIELD MEASURCMENTS AND ANALYTICAL DATA - SEDIMENTS - DEA.TH VALLEY SHEET

$\subseteq R L I . D$

DOE I.D.

JVCF 00251 $06-36.4675-116.5250-4-59-000$ JVCF 00351 $06-36.4578-116.53 E 8-4-59-000$ JVCF004SI $06-36.4514-116.50 \overline{1}]-4-59-000$ JVCr005SI $06-36.4067-116.5069-4-59-000$ JVCF006SI $06-36.3895-116.51 E 4-4-59-000$ JVCF00751 06-36.3071-116.5170-4-59-000 JVCFOOSSI $06-36.3254-116.5620-4-59-000$ JVCFOIOS1 06-36.3401-116.5926-4-59-000 JVCFOIISI $06-36.3514-116.6335-4-59-000$ JVCF012S1 06-36.3620-116.651-4-59-000 JVCF01351 06-36.3757-116. 67 $=7-4-59-000$ JVCG00IS1 06-36.2666-116.434-4-59-000 JVCG002S1 06-36.2659-116.4638-4-59-600 JVCG00351 00-36.3044-116.4286-4-59-000 JVCCO04S1 06-36.3046-116.42745-4-59-000 JVCCO0551 06-36. 3451-116.4315-4-59-000 JVCC005S1 06-36.3716-116.4205-4-59-000 JVCC00751 06-36.4044-116.4411-4-59-000 JVCG008S1 06-36.4168-116.4728-4-59-000 JVCCOOSS1 06-36.3904-116.405-4-59-000 JVCGOIOS1 $06-36.4418-116.4875-4-59-000$ JVCGOIISI 32-36.4197-116.3952-4-59-000 JVCCOIDS1 32-36.4395-116.4203-4-59-000 JVCCOI351 32-36.4535-116.4015-4-59-000 JVCCO1451 32-36.4875-116.3350-4-59-000 JVCCO15S1 32-36.4927-116. $3105-4-59-000$ JVCCOISS1 32-36.4927-116. $3350-4-59-000$ $3 V C C 0175132-36.4694-116.4689-4-59-000$ JVCCOITI 32-36.4694-116.448 JVCGOIOSI 32-36.3103-116.380.-4-59-000 JVCCODOS1 32-36.3140-116.3349-4-59-000 JVCCODISI 32-36.3409-116. $3165-4-59-000$ JVCCO25I 32JVCCO2351 32-36.3220-116. $3511-4-59-000$ JVCOC251 32 -36.3250-116. JVCG025S1 32-36.4015-116. $270-4-59-000$ JVCCODSI $32-36.3992-116.300=-4-59-000$ $3 v C G 0275132-36.3799-116.3021-4-59-000$ JVCCO2OS1 32-36.4260-116. $2913-4-59-000$ JVCCO2S1 32 $36.4260-116.291104-59-000$ כVCOO30S1 32 -36.4243-116.3322 -4-59-000 JVCO3DI $32-36.4243-116.3322-4-59-000$ JVCC03251 32 $36.4780-116.3176-4-59-000$ JVCOO3351 32-36.4260-116.3694-4-59-000 JVCCO3351 32 $36.4260-116.3694-4-59-000$ JVCHODS1 32 $36.4864-116.10609-4-59-000$ JVCH00351 32-36.4763-116.0363-4-59-000 JVCHODS1 32 $36.4763-116.0363-4-59-000$ JVCHOSS1 32-36.4571-116.0201-4-59-000 JVCHOOSS1 32-36.4234-116.061-4-59-000 JVCHOOS1 32 $36.4234-116.0618-4-59-000$ JVCO0 $132-36.4287-116.0318-4-59-000$ JVCC10081 32 $36.4111-116.035 .5-4-59-000$ JVCH009S1 $32-36.3764-116.0642-4-59-000$

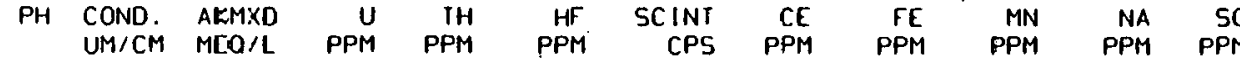

$\begin{array}{rrr} & & \\ 2.6 & -4 & 7 \\ 2.7 & 21 & 4 \\ 3.6 & 10 & 5 \\ 4.0 & 5 & 5 \\ 2.9 & 6 & 8 \\ 3.0 & 7 & 1 \\ 2.3 & -4 & 5 \\ 3.0 & 11 & 11 \\ 3.3 & 14 & 6 \\ 2.6 & 6 & \\ 2.8 & 6 & 7 \\ 2.3 & -4 & 0 \\ 4.9 & 6 & 11 \\ 3.4 & 8 & 9 \\ 2.8 & -4 & 2 \\ 3.1 & -4 & 0 \\ 3.7 & 15 & 14 \\ 3.0 & 7 & 4 \\ 4.0 & 8 & 5 \\ 3.2 & -4 & 4 \\ 3.9 & M & 13 \\ 3.6 & 13 & 9 \\ 3.2 & 10 & 15 \\ M & M & M \\ M & M & M \\ M & M & M \\ 4.1 & M & 7 \\ 3.6 & -4 & 14 \\ 4.1 & 12 & 11 \\ 3.2 & -4 & 0 \\ 3.0 & -4 & 11 \\ 3.2 & 11 & 14 \\ 3.3 & M & 0 \\ 3.6 & 8 & 15 \\ 2.7 & 5 & 5 \\ 2.2 & -4 & 7 \\ 2.8 & 5 & 1 \\ 3.7 & 6 & 7 \\ 2.0 & .4 & 7 \\ 3.4 & 5 & 11 \\ 3.6 & 5 & 10 \\ 2.1 & 5 & 6 \\ 2.2 & 10 & 18 \\ 3.9 & -4 & 0 \\ 2.8 & -4 & 11 \\ 4.4 & 21 & 19 \\ 4.0 & 12 & 14 \\ 4.1 & 5 & 4 \\ 2.9 & 11 & 0 \\ 11.0 & 15 & 10 \\ 3.4 & -4 & 10 \\ 3.6 & 6 & 11 \\ 2.8 & 7 & 8 \\ 3.5 & 14 & 13 \\ 3.7 & 13 & 1 \\ & & \end{array}$

$\begin{array}{rrr}30 & M & M \\ 25 & 51 & 17700 \\ 25 & 49 & 12000 \\ 25 & M & 8100 \\ 20 & 54 & 13300 \\ 30 & 74 & 33100 \\ 20 & M & M \\ 25 & 67 & 23600 \\ 25 & 51 & 28700 \\ 25 & 32 & 8100 \\ 25 & 29 & 19200 \\ 25 & M & M \\ 35 & 99 & 42100 \\ 35 & M & 30900 \\ 24 & 16 & 8700 \\ 14 & M & 8600 \\ 26 & 104 & 28300 \\ 38 & 65 & 18200 \\ 35 & 65 & 16500 \\ 23 & 50 & 8900 \\ 19 & M & M \\ 21 & 93 & 19700 \\ 46 & 86 & 19700 \\ 30 & M & M \\ 19 & M & M \\ 25 & M & M \\ 41 & M & M \\ 50 & 50 & 8800 \\ 53 & 93 & 18800 \\ 64 & 19 & 6300 \\ 41 & 55 & 10700 \\ 35 & -20 & 21800 \\ 36 & M & M \\ 29 & 62 & 17800 \\ 23 & 32 & 11500 \\ 25 & -20 & 3100 \\ 21 & 90 & 12100 \\ 24 & 17 & 10000 \\ 18 & M & 9600 \\ 17 & -20 & 11700 \\ 21 & 33 & 9300 \\ 17 & 20 & 6700 \\ 28 & 125 & 12800 \\ 26 & M & 6500 \\ 45 & M & M \\ 30 & 146 & 39100 \\ 25 & 99 & 27000 \\ 45 & M & 12400 \\ 30 & M & M \\ 35 & 87 & 21900 \\ 35 & M & 10900 \\ 35 & 31 & 24300 \\ 55 & M & 27500 \\ 25 & 87 & 35300 \\ 25 & 85 & 22000\end{array}$

PPM PPM

$5200 \quad 30$ $\begin{array}{rrr}M & 20 \\ M & 50\end{array}$ $6100 \quad 110$ $5600 \quad 20$ $4200 \quad 130$ $M \quad 30$ 
'ABLE B-I IABULATION OF SEY FIELD MEASUREMENTS AND ANALYTICAL DATA - SEDIMENIS-- DEATH VALLEY SHEET

$\leqq R L, D$

DOE I.D

JVCHOIISI 32-36.4871-116.1555-4-59-000 JVCHOIJSI 32-36.4907-116. 1835-4-59-000 JVCHOI 3SI 32-36.4787-116.2234-4-59-000 JVCHOI4SI $32-36.4489-116.2366-4-59-000$ JVCHO15S1 32-36.4172-116.2143-4-59-000 JVCHOI6SI $32-36.4606-116.1805-4-59-000$ JVCHO17SI 32-36.4434-116.1573-4-59-000 JVCH018S1 32-36.4258-116.1659-4-59-000 JVCHOI9SI $32-36.4239-116.1339-4-59-000$ JVCHO20S1 32-36.3601-116.0939-4-59-000 JVCHO2ISI $32-36.3501-116.1163-4-59-000$ JVCH022SI 32-36.3637-116.0354-4-59-000 JVCH02351 32-36.3485-116.0492-4-59-000 JVCHO2451 $32-36.3374-116.0317-4-59-000$ JVCHO25S1 32-36.3180-116.0324-4-59-000 JVCH0ट6SI 32-36.2631-116.0031-4-59-000 JVCH027SI 32-36.2643-116.0566-4-59-000 JVCH028SI 32-36.2965-116.0599-4-59-000 JVCH029S1 $32-36.2875-116.0824-4-59-000$ JVCHO3OSI 32-36.2653-116.1026-4-59-000 JVCH031SI 32-36.2753-116. 1337-4-59-000 JVCH032SI $32-36.2872-116.1550-4-59-000$ JVCH033SI 32-36.2681-116.2113-4-59-000 JVCH034SI $32-36.2828-116.1855-4-59-000$ JVCHO35SI $32-36.2997-116.1882-4-59-000$ JVCH036SI 32-36.3162-116.2120-4-59-000 JVCH037SI $32-36.3384-116.2274-4-59-000$ JVCH038SI 32-36.3655-116. 2463-4-59-000 JVCH039SI 32-36.3485-116.1944-4-59-000 JVCH040SI 32-36.3564-116.1709-4-59-000 JVCHO4ISI $32-36.3626-116.1439-4-59-000$ JVCHO42SI $32-36.3457-116.1471-4-59-000$ JVDA00ISI 06-36.2309-117.9619-4-59-000 JVDA002SI 06-36.2238-117.9357-4-59-000 JVDA00351 06-36.2095-117.9186-4-59-000 JVDA004S1 06-36.2017-117.8933-4-59-000 JVDA005S1 06-36.1856-117.8613-4-59-000 JVDA006S1 06-36.1698-117.8590-4-59-000 JV0A007S1 06-36.1624-117.8827-4-59-000 OVDA008S1 06-36.1467-117.8505-4-59-000 JVDA00951 06-36.1358-117.9053-4-59-000 JVDAOIOSI 06-36.1384-117.9489-4-59-000 JVDAOIISI 06-36.0931-117.9619-4-59-000 JVDA012S1 06-36.0549-117.9382-4-59-000 JVDA01351 06-36.0654-117.8839-4-59-000 JVDA014SI 06-36.0880-117.8734-4-59-000 JVDA015S1 06-36.1013-117.8578-4-59-000 DVDAO1651 06-36.0480-117.9758-4-59-000 DVDA01751 06-36.0279-117.9697-4-59-000 JVDA0I8SI 06-36.0229-117.9522-4-59-000 JVDA019S1 06-36.0853-117.9464-4-59-000 DVDA020S1 06-36.1229-117.9727-4-59-000 JVDA02ISI 06-36.1565-117.9771-4-59-000 JVDAO22SI $06-36 \cdot 1803-117.9761-4-59-000$

\begin{tabular}{|c|c|c|c|c|}
\hline$D_{H}$ & $\begin{array}{l}\text { CDND. } \\
\text { UM/CM }\end{array}$ & $\begin{array}{l}\text { AKMXO } \\
M E O / L\end{array}$ & $\begin{array}{r}U \\
\text { PPM }\end{array}$ & $\begin{array}{r}\text { IH } \\
\text { PPM }\end{array}$ \\
\hline- & 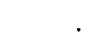 & • & 3.1 & 7 \\
\hline - & . & . & 2.1 & -4 \\
\hline . & . & . & 4.1 & -4 \\
\hline & • & . & 2.4 & 11 \\
\hline . & . & . & 2.8 & 9 \\
\hline • & . & . & 2.2 & -4 \\
\hline . & r. & . & 4.2 & 13 \\
\hline . & . & . & 4.1 & -4 \\
\hline . & . & . & 4.6 & 12 \\
\hline - & . & . & 2.5 & 8 \\
\hline & & . & 3.1 & 15 \\
\hline . & . & . & 3.1 & \\
\hline - & . & . & 3.9 & \\
\hline & . & . & 2.9 & \\
\hline & & · & 2.8 & -4 \\
\hline . & & : & $\begin{array}{l}2.5 \\
2.6\end{array}$ & \\
\hline & . & . & 2.5 & -4 \\
\hline . & & . & 3.6 & 11 \\
\hline . & . & . & 3.3 & \\
\hline & & . & 2.3 & \\
\hline . & & . & 3.1 & \\
\hline - & $\cdot$ & - & 3.7 & 14 \\
\hline 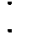 & & . & 2.5 & 18 \\
\hline . &. & $\cdot$ & 3.6 & It \\
\hline & & 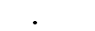 & 2.8 & \\
\hline - & . & . & 4.3 & 16 \\
\hline - & . & . & 2.7 & \\
\hline - & . & . & 3.5 & \\
\hline . & . & . & 4.1 & \\
\hline . & & · & 3.9 & -4 \\
\hline . & $r$ & $\cdot$ & 3.0 & ZC \\
\hline . & & 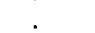 & 4.8 & 15 \\
\hline . & . & . & 3.5 & \\
\hline • & . & . & 4.0 & 14 \\
\hline . & . & . & 4.6 & 17 \\
\hline - & . & . & 2.6 & \\
\hline - & . & . & 5.0 & 25 \\
\hline - & . & . & 4.2 & \\
\hline - & . & . & 3.9 & 12 \\
\hline · & 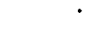 & . & 3.8 & \\
\hline · & . & - & 3.9 & \\
\hline . & & . & 4.0 & \\
\hline . & 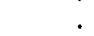 & . & 4.4 & 17 \\
\hline . & • & . & 5.3 & 15 \\
\hline . & . & . & 4.1 & 13 \\
\hline - & - & · & 4.8 & \\
\hline & & - & 2.8 & \\
\hline • & & . & 2.9 & \\
\hline • & & . & 2.4 & \\
\hline & & · & 3.2 & \\
\hline & & & 3.6 & \\
\hline
\end{tabular}

SCINI
CPS
20
30
30
25
30
25
30
30
35
30
25
30
20
25
25
25
25
20
20
25
25
25
35
20
20
20
35
30
20
28
55
35
60
60
55
60
50
55
50
70
60
65
50
50
50
40
60
45
50
50
45
35
35
35
42

CE $66 \quad 22000$ 0 M $\begin{array}{rr}100 & 11300 \\ 99 & 24700\end{array}$ 9924700 11426600 $M \quad M$ $51 \quad 17600$ 5328200 $M$
$M$ 23000 $\begin{array}{ll}-20 & 7800\end{array}$ 4000
43 4325400 $M \quad M$ $31 \quad 18700$ $54 \quad 22800$ $34 \quad 15100$ $103 \quad 34400$ $\begin{array}{ll}103 & 11900 \\ 73 & 27200\end{array}$ $\begin{array}{ll}73 & 27200 \\ 30 & 24400\end{array}$ 101 20800 $90 \quad 26000$ 204600 6415200

$\begin{array}{rrr}M N & N A & S C \\ P P M & P P M & P P M \\ & & \\ 400 & 8500 & 4.9 \\ 110 & 3200 & 1.6 \\ 390 & 9200 & 0.0 \\ 230 & 8500 & 4.1 \\ 530 & 102900 & 5.0 \\ 230 & 8000 & 3.2 \\ 510 & 11800 & 6.0 \\ 150 & 3600 & 0.7 \\ 300 & 6600 & 7.0 \\ 400 & 8800 & 5.0 \\ 640 & 13100 & 4.9 \\ 330 & 7500 & 0.7 \\ 340 & 8600 & 4.0 \\ 160 & 3900 & 2.6 \\ 100 & 3600 & 1.6 \\ 220 & 7500 & 5.5 \\ 540 & 8300 & 7.0 \\ 110 & 3800 & -0.1 \\ 200 & 4400 & 6.2 \\ 320 & 10300 & 6.2 \\ 340 & 11800 & 4.2 \\ 380 & 10800 & 4.8 \\ 380 & 11700 & 10.9 \\ 140 & 4700 & 1.4 \\ 430 & 11700 & 8.1 \\ 260 & 10100 & 6.1 \\ 330 & 11700 & 1.7 \\ 340 & 11900 & 7.0 \\ 0 & 4400 & 2.7 \\ 150 & 4200 & 5.8 \\ 310 & 8200 & 1.1 \\ 400 & 12400 & 7.8 \\ 1890 & 28000 & 13.3 \\ M & 176300 & 9.0 \\ 1550 & 26500 & 6.3 \\ M & -100 & 6.2 \\ 1660 & 23600 & 7.9 \\ M & -100 & 15.9 \\ 1970 & 21500 & 9.9 \\ M & -100 & 8.3 \\ 1840 & 21100 & 9.6 \\ M & -100 & 12.1 \\ 1720 & 27600 & 15.6 \\ M & 100 & 24.7 \\ 1420 & 22100 & 9.5 \\ -50 & 24000 & 9.4 \\ 320 & -100 & 6.8 \\ 330 & -100 & 19.5 \\ 2170 & 16200 & 15.0 \\ M & -100 & 31.0 \\ M & 25700 & 24.1 \\ M & -100 & 27.7 \\ 1630 & 20900 & 18.2 \\ M & -100 & 1.9 \\ 2160 & 18700 & 11.9\end{array}$

$1 I$
PPM

$2400 \quad 40$

$500 \quad 10$
$1900 \quad 50$

$1400 \quad 20$

$3200 \quad 60$

$1400 \quad 20$

$800 \quad 10$

800
$2300 \quad 40$

$2100 \quad 40$

$2700 \quad 60$

$2600 \quad 30$

900
3500

$\begin{array}{r}3500 \\ M \quad 60 \\ \hline\end{array}$

$3600 \quad 50$

$M \quad 120$

$M$
3600

$\begin{array}{rr}3600 & 50 \\ M & -20\end{array}$

660070

$M$
-300

$5500 \quad 60$

$M$
3300

$M$
15000

$M$

$\begin{array}{ll}M & 80\end{array}$

$M \quad 140$

$3400 \quad 70$

$6500 \quad 120$

1 $M \quad M$

$\begin{array}{lr}M & M \\ M & 70\end{array}$

$12300 \quad 160$

$7800 \quad M$

$M$
2000

$M \quad 40$

$M \quad 40$

520

5200 130
$M$ 
IABLE B-I TABULATION OF KEY FIELD MEASUREMENTS AND ANALYIICAL DAIA - SEDIMENTS-- DEATH VALLEY SHEET

$-\quad S R L I . D$.

DOE I.D.

JVDA024SI 06-36.2189-117. 8:99-4-61-000 JVDA025SI $06-36.2170-117.7774-4-59-000$ JVDA026SI $06-36 \cdot 1802-117.7781-4-59-000$ JVDA027S1 $06-36.1895-117.8112-4-61-000$ JVDA028SI 06-36.1662-117.8257-4-59-000 JVDA029SI 06-36.1555-117.7769-4-59-000 JVDA030S1 06-36.1275-117.7776-4-59-000 JVDA03ISI 06-36.1284-117.8088-4-61-000 JVDA032SI 06-36.1048-117.8069-4-59-000 SVDA03351 06-36.0970-117.8144-4-61-000 JVDA034SI 06-36.0962-117.7849-4-59-000 JVOA035SI 06-36.0681-117.7791-4-61-000 JVDA03651 06-36.0838-117.8160-4-59-000 JVDA03751 06-36.0416-117.8851-4-61-000 JVDA038SI 06-36.0395- $\mid 17.8555-4-61-000$ JVOA039S1 06-36.0106-117.8561-4-61-000 JVDA040S1 06-36.0089-117.8157-4-61-000 JV0A04 ISI 06-36.0092-117.7874-4-61-000 JVDA042SI 06-36.0688-117.8145-4-59-000 JVDA043SI 06-36.0611-117.8124-4-59-000 JVOA044S1 06-36.0555-117.8212-4-59-000 JVDAO45SI 06-36.0530-117.8134-4-59-000 JV0800151 06-36.2166-117.7411-4-59-000 JVDB002S1 06-36.1868-117.7423-4-51-000 I JVDO003S1 06-36.1578-117.7414-4-59-000 JVBO 51 06-36. $1227-117.7388-4-61-000$ JV0005S1 06-36.0667-117.7385-4-61-000 วख000751 06-36.0667-117. $386-4-61-000$ วVD00051 06-36.0404-117.7473-4-61-000 Jै JVBOIOSI 06-36.0364-117. 6519-4-61-000 JVB JVD01 351 06-36.0674-117.5554-4-61-000 JVBO 551 06-36.0686-117. JV0 JVDOISI 06-36. 1264-117. 7 JVDB016S1 06-36.1847-117.71056-4-61-000 כVDB01751 06-36.2131-117.6.302-4-61-000 JVDB018S1 06-36.2112-117.6563-4-61-000 JVDB0I9SI 06-36.1812-117.6512-4-61-000 JVBOen1 06-36.1587-117.65e1-4-61-000 3 Vo802151 06-36.1272-117.6519-4-61-000 jVOB02351 06-36.0132-117.7341-4-61-000 JV0B024Si $06-36.0150-117.6568-4-61-000$ JV0802551 06-36.0201-117.6156-4-61-000 Jv08026si 06-36.0076-117.5:354-4-61-000 Jv0802751 06-36.0392-117.5965-4-61-000 JVD802851 06-36.0098-117.5532-4-61-000 JV08029S1 06-36.0404-117.5067-4-61-000 Jv0B03isi $06-36.0388-117.5+26-4-61-000$ JVOB032S1 $06-36.0369-117.6 \geq 70-4-61-000$ JV0B03351 06-36.0697-117.6213-4-61-000

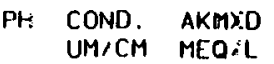

HF
PPM

SCINT

CPS PPM

$\begin{array}{cc}C E & F E \\ \text { PPM } & \text { PPM }\end{array}$

$79 \quad 26100$

11870900

735700

98. 33200

$\begin{array}{rr}65 & 39400 \\ -20 & 42800\end{array}$

44600
89

3738800

2748000

$55 \quad 23600$

$80 \quad 43100$

8043100

8040600

M

$M$

$M$

$M$

$-20 \quad 42900$

82. 34700

0340000

819200

43500

11599000

$36 \quad 27100$

96300
-13600

43800

1335200

1340200

7137600

20 55900

28600

$\begin{array}{rl}55 & 14400 \\ -20 & 59300\end{array}$

7935600

10652000

9438100

8 37400

109 35700

$94 \quad 4900$

40000

43300

34100

$76 \quad 39700$

35600

148221200

$\begin{array}{rl}-20 & 43600\end{array}$

$\begin{array}{rr}51 & 30900 \\ 188 & 133700\end{array}$ $\begin{array}{rrr}\text { MN } & \text { NA } & \text { SC } \\ \text { PPM } & \text { PPM }\end{array}$

$\begin{array}{rrr}1450 & 17200 & 8.4 \\ M & 17000 & 16.2\end{array}$

$\begin{array}{rrr}M & 17000 & 16.2 \\ 810 & -100 & 9.2\end{array}$

5400129005.5

M 1940013.1

$\begin{array}{lll}150 & 15200 & 6.5 \\ -40 & 17000 & 3.5\end{array}$

$1630 \quad 15400 \quad 9.1$

$2100 \quad 24200 \quad 16.9$

$\begin{array}{rrr}-100 & 8.0\end{array}$

$\begin{array}{llll}5.50 & 13700 & 10.8\end{array}$

M $22000 \quad 8.7$

1540 21800 12.9

$M$

$M$

$M$$$
25
$$

$M$
$M$

$\begin{array}{lll}520 & 17600 & 15.0 \\ & 1.5\end{array}$

$84021500 \quad 7.5$

$113025900 \quad 9.9$

$105031100 \quad 14$.

$\begin{array}{lll}1370 & 20400 & 8.3\end{array}$

930 3.8

1020

950

900 23700 12.3

9502950016.4

$470 \quad 16500 \quad 7.0$

1220 21800 9.3

1170.27000

07035000

80 25800

77022900

12.4

500126009.3

$\begin{array}{lll}740 & 21900 & 13.6\end{array}$

$7.50023200 \quad 8.9$

9202640010.1

$1140 \quad 16400 \quad 17.5$

850259005.8

$\begin{array}{rrr}1270 & 26200 & 11.8\end{array}$
$\begin{array}{rr}I 1 & V \\ \text { PPM } & \text { PPM }\end{array}$

$M \quad 80$

$\begin{array}{rr}M & M \\ M & 110\end{array}$

$\begin{array}{rr}5300 & 100 \\ M & 100\end{array}$

$6600 \quad 80$

$\begin{array}{rr}M & 150 \\ 4400 & 100\end{array}$

$6000 \quad 60$

$\begin{array}{rr}M & 230 \\ 5100 & 110\end{array}$

$M$

$5000 \quad 120$

$\begin{array}{ll}M & M \\ M & M\end{array}$

$\begin{array}{ll}M & M \\ M & M\end{array}$

$4700 \quad 90$

$3600 \quad 70$

$2200 \quad 120$

$-400 \quad 90$

6900210

6400
3500
670

$6100 \quad 120$

$5100 \quad 130$

$4400 \quad 100$

$5200 \quad 110$

$6200 \quad 160$

590070

$8400 \quad 220$

$7300 \quad 150$

$-400 \quad 110$
$6200 \quad 110$

$4300 \quad 80$

$3700 \quad 80$

$3100 \quad 80$

$4300 \quad 80$

$\begin{array}{rr}-500 & 100 \\ 3600 & 80\end{array}$

$5200 \quad 110$

$6600 \quad 540$

$4600 \quad 100$
$9600 \quad 420$ 


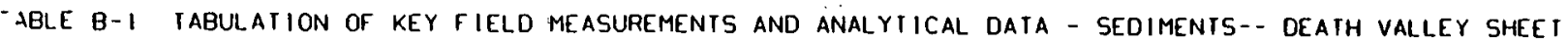

SRL I.D.

DOE I.D

PH COND. AKMXO

JVDB034S1 $06-36.0651-117.5889-4-61-000$ 2VDB035S1 $06-36.0664-117.5541-4-61-000$ JVDB036S1 $06-36.0664-117.5123-4-59-000$ JVDB03751 06-36.0972-117.5104-4-61-000 JVDO038SI $06-36.1353-117.5170-4-61-000$ JVDBO4 0S1 $06-36.1868-117.5195-4-61-000$ JVDB04 151 06-36.2152-117.5122-4-61-000 JV08042SI $06-36.2199-117.5473-4-59-000$ JVDB01435I $06-36.1860-117.5485-4-61-000$ JVDB044SI $06-36.1598-117.5480-4-61-000$ วVDB04551 $06-36.1298-117.5510-4-61-000$ JV0B0465i $06-36.0927-117.5512-4-61-000$ วVDB0475I $06-36.0966-117.5878-4-61-000$ JVDB048Si $06-36.1294-117.5889-4-61-000$ JVDB0495i $06-36.1544-117.5895-4-61-000$ JVDB050SI $06-36.1849-117.5928-4-61-000$ JVDB0515i $06-36.2194-117.5920-4-61-000$ JVDB0525i $06-36.2187-117.6283-4-59-000$ JV080535! 06-36 1808-117.6292-4-61-000 JVDB054S1 $06-36.1574-117.6272-4-59-000$ JVDB05551 06-36.1250-117.6254-4-51-000 JVDB0565i $06-36.0932-117.6217-4-59-000$ JVDC00151 $06-36.2402-117.3842-4-59-000$ of JVDCO02SI 06-36.2368-117.4257-4-59-000 JVDC00351 06-36.1981-117.3973-4-59-000 JVDC004SI $06-36.1977-117.4268-4-59-000$ JVDC00551 06-36. $079-117.4550-4-59-000$ JVDC0065 $06-36.2079-117.4550-4-59-000$ JVDC0075 $06-36.1333-117.3865-4-59-000$ JVDC00851 06-36. $1174-117.3546-4-59-000$ JVDC009si $06-36.0894-117.3464-4-59-000$ วVDC01051 05-36.1081-117.3843-4-59-000 JVDCOIISI 06-36.1638-117.3099-4-59-000 JVDC01251 06-36. 1962-117.3250-4-59-000 JVDC01351 06-36. 2303-117.3413-4-59-000 JVOC01451 06-36.1945-117. $2847-4-59-000$ JVDC015Si 05-36. 2155-117.2730-4-59-000 JVDC01651 05-36 2431-117-2642-4-59-000 VVC0175 06-36. 1472-117. $2606-4-59-000$ כVOCOIBSI 06-36.1360-117.2915-4-59-000 JVC0195 $06-36.1360-117.2915-4-59-000$ JVC02051 06-36.0506-117.2743-4-59-000 כVDCO2151 06-36.0284-117. गVOC02351 06-36.0261-117.3148 כण JVDC $35106-36.0161-117.31489-4-59-000$ JVCO2451 06-36.0457-117.3423-44-59-000 כVDC02651 06-36.0646-117.3011-4-59-000 गV כVDC02851 06-36.0116-117.4760-4-61-000 JVDC029S1 06-36.0062-117.4501-4-61-000 JVDC03051 06-36.0398-117.4461-4-61-000 כVDC03ISI 06-36.0365-117.4779-4-59-000

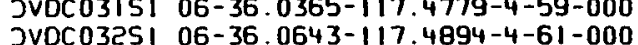


'ABLE B-1 TABULATION OF KEY FIELD MEASUREMENTS AND ANALYTICAL DATA - SEDIMENIS-- DEATH VALLEY SHEET

$\sum_{i \rightarrow 0} 1 . D$

DOE I.D.

JVOC03351 06-36.0688-117.4526-4-61-000 วVDC034S1 $06-36.1157-117.4439-4-59-000$ JVDC035SI $06-36.0811-117.4963-4-61-000$ JVDD00ISI 06-36.1269-117.2142-4-59-000 JV00002SI 06-36.0912-117.2282-4-59-000 JV0D00351 06-36.0310-117.2201-4-59-000 JV0D004S1 06-36.0415-117.0715-4-59-000 JVDD00551 06-36.0217-117.0693-4-59-000

- JVDD00651 06-36.0325-117.0945-4-59-000 JVDD00751 06-36.0302-117.1385-4-59-000 JV0000851 06-36.0302-117.1683-4-59-000 JVDD009SI 06-36.0390-117.1995-4-59-000 JVDD0I0S1 06-36.0496-117. 2263-4-59-000 JVDDOIISI 06-36.1600-117.2305-4-59-000 JVOD012S1 06-36.1936-117.1825-4-59-000 JVD0 351 06-30. 1957-117.2294-4-59-000 JNDO1451 06-36.2152-117.2036-4-59-000 JVD0155 06-36. JVD01751 06-36.01124-117.20252-4-59-000 JV0001851 06-36.1134-117.1501-4-59-000 JVDD01950 06-36.1167-117.0991-4-58-000 JVDD020S1 06-36.0722-117.1350-4-59-000 JVDF00IS1 $06-36.0681-117.1544-4-59-000$ JVOF00ISI 06-36.2349-116.6353-4-59-000 JVDF 00351 06-36.2066-116.6419-4-59-000 JVOF 004S1 06-36.1947-116.6026-4-59-000 JVDr005si 06-36. 1716-116.6229-4-59-000 Jvor00651 06-36.1750-116.5989-4-59-000 JV 00751 06-36. $1865-116.5638-4-59-000$ JVDF008S1 06-36.2226-116.5635-4-59-000 JVDF 009S1 06-36. 1552-116.5633-4-59-000 JVOF0I0S1 06-36. $1204-116.5587-4-59-000$ JVOF0lisi 06-36.0921-116.5487-4-59-000 JVDFol 251 06-36.0571-116.5505-4-59-000 JVDF01 351. 06-36.0608-116.5798-4-59-000 JVOF014S1 06-36.0314-116.5832-4-59-000 JVOF 01551 06-36.0550-116.5080-4-59-000 JVDO00IS1 06-36.2473-116.4913-4-59-000 JVOG002SI $32-36.2407-116.4531-4-59-000$ JVD6003si 32-36.2138-116.4018-4-59-000 JVOG004SI 32-36.1973-116.3734-4-59-000 JVDG005S1 32-36. $1918-116.3474-4-59-000$ JVDG00651 32-36.1725-116.3285-4-59-000 JVOG007SI 32-36.1443-116.3178-4-59-000 JVDC008SI 32-36..0893-116.2973-4-59-000 JVDG009SI 32-36.0462-116.2960-4-59-000 JVDG010S1 32-36.0142-116.2951-4-59-000 JV0601151 32-36.0132-116.2639-4-59-000 JVDGOILSI 06-36.1958-116.4220-4-59-000 JVDG01351 06-36.1719-116.4258-4-59-000 JVOG014S1 06-36.1687-116.4070-4-59-000 $\begin{array}{ll}\text { JVDG0ISS1 } & 06-36.1390-116.4271-4-59-000 \\ \text { JVDG0I6S1 } & 06-36.1398-116.3984-4-59-000\end{array}$
PH COND AKMXD UM/CM REOIL

$\begin{array}{rrr}N I & C E & F E \\ C S & P P M & P P M \\ & & \\ 40 & 108 & 62200 \\ 25 & 78 & 30500 \\ 35 & 169 & 75600 \\ 80 & M & 37700 \\ 80 & 88 & 39300 \\ 40 & 108 & 39000 \\ 20 & M & 26900 \\ 00 & 49 & 9900 \\ 40 & 57 & 49000 \\ 40 & -20 & 96500 \\ 00 & 162 & 56800 \\ 60 & M & 31300 \\ 00 & 68 & 42000 \\ 90 & -20 & 10100 \\ 20 & M & M \\ 00 & 82 & 41300 \\ 30 & -20 & 27900 \\ 80 & 39 & 30000 \\ 80 & 75 & 42300 \\ 00 & M & 11400 \\ 00 & M & M \\ 00 & 84 & 40200 \\ 80 & 81 & 46200 \\ 20 & 54 & 31900 \\ 45 & 77 & 40100 \\ 52 & M & M \\ 35 & 58 & 23000 \\ 35 & 82 & 26700 \\ 37 & 40 & 23400 \\ 39 & -20 & 36400 \\ 24 & 64 & 31200 \\ 37 & M & 31900 \\ 45 & 78 & 34300 \\ 55 & 68 & 29000 \\ 48 & 68 & 38400 \\ 51 & M & 31400 \\ 63 & M & 27600 \\ 61 & 38 & 20200 \\ 63 & 25 & 12100 \\ 34 & 90 & 36000 \\ 38 & 82 & 36700 \\ 45 & 40 & 12000 \\ 43 & 49 & 12300 \\ 23 & 65 & 25700 \\ 38 & M & M \\ 40 & 93 & 30100 \\ 40 & 80 & 7700 \\ 40 & 62 & 20400 \\ 54 & 87 & 29000 \\ 40 & 59 & 25400 \\ 42 & M & M \\ 49 & 92 & 36300 \\ 48 & -20 & 5900 \\ 42 & 91 & 33000 \\ 48 & M & M \\ & & \end{array}$

$\begin{array}{rrr}M N & \text { NA } & \text { SC } \\ \text { PPM } & \text { PPM } & \text { PPM } \\ & & \\ 1110 & 20200 & 19.5 \\ 910 & 13900 & 5.1 \\ 920 & 14900 & 26.5 \\ 490 & 10400 & 5.7 \\ 830 & 8900 & 11.2 \\ 480 & 7800 & 8.2 \\ 1040 & 11300 & 9.0 \\ 220 & 4400 & 3.3 \\ 540 & 6500 & 8.4 \\ 910 & 2800 & 12.6 \\ 1350 & 8900 & 8.6 \\ 880 & 5700 & 8.1 \\ 930 & 10400 & 12.9 \\ 250 & 2100 & 4.1 \\ 1180 & 5800 & 9.1 \\ 960 & 6500 & 13.4 \\ 1240 & 6700 & 8.3 \\ 490 & 4500 & 10.3 \\ 1040 & 7800 & 7.3 \\ 380 & 1500 & 3.9 \\ 410 & 2300 & 2.7 \\ 670 & 5000 & 11.0 \\ 1050 & 4800 & 12.4 \\ 670 & 5800 & 10.4 \\ 790 & 21700 & 8.1 \\ 230 & 6800 & -0.3 \\ 420 & 10600 & 7.8 \\ 600 & 17300 & 9.6 \\ 440 & 11700 & 6.7 \\ 810 & 20500 & 7.1 \\ 770 & 20300 & 3.3 \\ 640 & 16200 & 9.9 \\ 730 & 21400 & 5.8 \\ 630 & 18500 & 5.8 \\ 840 & 23500 & 10.0 \\ 800 & 21800 & 5.8 \\ 440 & 10100 & 6.8 \\ 730 & 20000 & 6.2 \\ 230 & 7000 & 3.6 \\ 520 & 15100 & 10.0 \\ 410 & 13600 & 7.3 \\ 180 & 6500 & 3.4 \\ 330 & 10900 & 4.2 \\ 390 & 13800 & 6.5 \\ M M & 13100 & -0.5 \\ 420 & 15600 & 5.4 \\ 140 & 5900 & 2.0 \\ 220 & 8300 & 6.4 \\ 380 & 13100 & 8.8 \\ 380 & 14400 & 6.6 \\ 630 & 20800 & -0.2 \\ 380 & 13200 & 11.0 \\ 150 & 5700 & 1.5 \\ 430 & 17300 & 8.2 \\ 530 & 19900 & 0.6 \\ & & \end{array}$

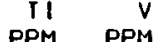

$6400 \quad 150$

$2600 \quad 90$

$5300 \quad 130$

$5400 \quad 120$

$2400 \quad 110$

$5400 \quad 80$

$\begin{array}{ll}4000 & 20 \\ -400 & 70\end{array}$

$2400 \quad 70$

$4500 \quad 100$

3000
4100

$800 \quad 20$

$4100 \quad 100$

$\begin{array}{ll}5100 & 100 \\ 3100 & 130\end{array}$

$2300 \quad 60$

420090

$1400 \quad 40$

320070

$5100 \quad 110$

$\begin{array}{rr}3600 & 70 \\ 4800 & 110\end{array}$

$1200 \quad 20$

$2700 \quad 60$

$3500 \quad 80$

$4600 \quad 80$

440090

$\begin{array}{rr}3900 & 70 \\ 13500 & 80\end{array}$

$3400 \quad 60$

$5200 \quad 100$

$\begin{array}{ll}4300 & 80 \\ 1900 & 30\end{array}$

$3900 \quad 70$ 
TABLE B-I TABULATION OF KEY FIELD MEASUREMENTS AND ANALYTICAL DATA - SEDIMENTS-- OEATH VALLEY SHEET

SRL $\quad$ P.D.

DOE I.D.

ZVDG017SI $06-36.1103-116.4386-4-59-000$ วVDGOI8SI $06-36.0984-116.4438-4-59-000$ วVDGOISSI $06-36.0745-116.4673-4-59-000$ JVDCOZOSI 06-36.0494-116.4965-4-59-000 JVDG02ISI $06-36.0365-116.4575-4-59-000$ JVDG023S $06-36.0215-116.4622-4-59-000$ 2V0G024SI 06-36.2335-116.3689-4-59-000 JVDG02551 06-36.2322-116.3200-4-59-000 JVDG026S1 06-36.1938-116.3150-4-59-000 JVDG027SI 06-36.1290-116.3027-4-59-000 JVDH002SI $32-36.2332-116.0141-4-59-000$ JVDH003SI 32-36.2437-116.0852-4-59-000 JVOH004SI 32-36.2059-116.0228-4-59-000 JVDH005SI 32-36.1917-116.0556-4-59-000 JVDH006SI $32-36.1998-116.0865-4-59-000$ JVOH00751 32-36.1593-116.0882-4-59-000 JVDH008SI 32-36.1540-116.0580-4-59-000 JVH009SI $32-36.1316-116.0544-4-59-000$ JVOHOIISI 32-36.1306-116.0115-4-59-000 JVOHOIZSI 06-36.1611-116.1393-4-59-000 ZVOHOI3SI 06-36.1441-116.1670-4-59-000 JVDHOI4SI 06-36.1219-116.1742-4-59-000 JVDHOISSI 32-36.1951-116.1354-4-59-000 JVDHO16SI 32-36.2305-116. 1492-4-59-000 JVDH017S1 06-36.1880-116.1789-4-59-000 JVDHOI8SI 06-36.2242-116.1919-4-59-000 JVDHO1951 06-36.1304-116.1239-4-59-000 JVDHO20SI 06-36.125I-116.0998-4-59-000 JVDHOCISI 06-36.1012-116.0800-4-59-000 2VDH023Si $06-36.0505-116.0231-4-59-000$ JVDH024SI 06-36.0675-116.0402-4-59-000 JVDH025SI 06-36.0071-116.1757-4-59-000 JVDH026SI 06-36.0229-1 16.1543-4-59-000 JVDH0275I 06-36.0425-116.1535-4-59-000 JVDH028SI 06-36.0088-1 16.2038-4-59-000 JVDH029SI 06-36.0390-116.2065-4-59-000 JVDH030SI 06-36.0916-116. 1910-4-59-000 JVDH03ISI $06-36.0612-116 \cdot 1888-4-59-000$
COND. AKMXO
UM/CM MEO/L

$\begin{array}{rrr}\text { U } & \text { IH } & \text { HF } \\ \text { PPH } & \text { PPM } & \text { PPM } \\ 3.2 & M & \\ 3.2 & 9 & 11 \\ 4.2 & 14 & 11 \\ 3.0 & 14 & 6 \\ 7.7 & 12 & 9 \\ 3.6 & -4 & 3 \\ 2.4 & 12 & 6 \\ 2.8 & 9 & 9 \\ 2.7 & 7 & 4 \\ 3.1 & 6 & 6 \\ 3.1 & -4 & 0 \\ 1.7 & -4 & 0 \\ 2.2 & -4 & 7 \\ 2.1 & 6 & 5 \\ 2.0 & 10 & 6 \\ 5.6 & -4 & 6 \\ 3.4 & -4 & 0 \\ 3.9 & 7 & 5 \\ 2.8 & -4 & 4 \\ 2.7 & -4 & 7 \\ 2.5 & -4 & 0 \\ 2.8 & 9 & 7 \\ 2.8 & 13 & 7 \\ 2.9 & M & 9 \\ 2.6 & -4 & 7 \\ 2.8 & 7 & 11 \\ 2.8 & 8 & 9 \\ 2.3 & 13 & 7 \\ 3.1 & 17 & 8 \\ 2.5 & 11 & 9 \\ 3.3 & 13 & 9 \\ 2.9 & 14 & 6 \\ 2.4 & 11 & 8 \\ 2.3 & -4 & 3 \\ 2.2 & 6 & 5 \\ 2.2 & -4 & 0 \\ 2.2 & -4 & 10 \\ 2.6 & 8 & 9 \\ 3.7 & 13 & 10 \\ 3.1 & -4 & 1 \\ 2.2 & 7 & 9 \\ 2.8 & 10 & 7 \\ 3.6 & 13 & 11 \\ & & \end{array}$

$\begin{array}{rrr}\text { SCINT } & \text { CE } & \text { FE } \\ \text { CPS } & \text { PPM } & \text { PPM } \\ & & \\ 42 & M & M \\ 56 & 61 & 25900 \\ 42 & 83 & 38200 \\ 43 & 34 & 21000 \\ 42 & 71 & 32200 \\ 50 & -20 & 17100 \\ 45 & 77 & 18600 \\ 29 & 89 & 21300 \\ 36 & 59 & 18300 \\ 29 & 49 & 15700 \\ 38 & M & 7700 \\ 20 & M & M \\ 26 & -20 & 13400 \\ 18 & 51 & 15300 \\ 20 & 98 & 14700 \\ 29 & M & M \\ 26 & 17 & 9100 \\ 32 & 39 & 14600 \\ 29 & 16 & 9400 \\ 22 & -20 & 12700 \\ 32 & M & M \\ 26 & 78 & 21700 \\ 22 & 50 & 13300 \\ 22 & M & M \\ 29 & 54 & 14700 \\ 28 & 52 & 14300 \\ 26 & 39 & 13300 \\ 24 & 81 & 23100 \\ 25 & 73 & 21500 \\ 22 & 60 & 24200 \\ 23 & 55 & 24100 \\ 21 & 71 & 19800 \\ 22 & 57 & 21200 \\ 18 & -20 & 9900 \\ 26 & 112 & 18900 \\ 33 & M & M \\ 32 & 30 & 13100 \\ 27 & 62 & 18600 \\ 47 & 79 & 27300 \\ 24 & 30 & 11300 \\ 27 & 35 & 12200 \\ 25 & 61 & 25200 \\ 34 & 39 & 27300 \\ & & \end{array}$

$\begin{array}{rrr}M N & N A & 5 C \\ P P M & P P M & P P M \\ & & \\ 410 & 15400 & -0.7 \\ 450 & 17000 & 7.4 \\ 490 & 20200 & 11.6 \\ 340 & 10400 & 5.7 \\ 850 & 27800 & 6.1 \\ 460 & 14000 & 6.6 \\ 410 & 15400 & 4.5 \\ 430 & 16100 & 7.0 \\ 480 & 20400 & 5.3 \\ 190 & 5600 & 3.3 \\ 410 & 13800 & 3.9 \\ 340 & 6400 & -0.5 \\ 320 & 5600 & 4.5 \\ 370 & 15000 & 2.7 \\ 440 & 9200 & 6.0 \\ 680 & 11000 & 4.7 \\ 170 & 2500 & 0.6 \\ 420 & 10100 & 3.4 \\ 350 & 10900 & 3.1 \\ 380 & 13700 & 4.5 \\ 330 & 9200 & 0.4 \\ 600 & 16600 & 8.9 \\ 220 & 6200 & 3.5 \\ 610 & 15000 & 4.1 \\ 600 & 17000 & 4.8 \\ 570 & 17900 & 6.5 \\ 350 & 9800 & 5.3 \\ 580 & 15100 & 4.9 \\ 530 & 14200 & 6.8 \\ 720 & 18200 & 8.3 \\ 590 & 16700 & 5.5 \\ 520 & 13100 & 6.2 \\ 640 & 15100 & 3.4 \\ 240 & 5800 & 3.5 \\ 520 & 13500 & 4.8 \\ 270 & 11400 & -0.2 \\ 520 & 20900 & 5.8 \\ 380 & 10900 & 5.7 \\ 590 & 16600 & 7.4 \\ 200 & 5400 & 3.8 \\ 1190 & 8500 & 4.2 \\ 610 & 17400 & 8.2 \\ 670 & 18500 & 6.6 \\ & & \\ & \end{array}$

T

PPM PPM

$\begin{array}{rr}M & 80 \\ M & 0 \\ M & 90 \\ 1900 & 30 \\ -400 & 90 \\ 3300 & 50 \\ 2600 & 50 \\ 2400 & 40 \\ 2900 & 50 \\ 1300 & 20 \\ 2200 & 40 \\ -250 & 20 \\ 1300 & 30 \\ 1700 & 40 \\ 1900 & 30 \\ 3200 & 70 \\ 600 & 10 \\ 1900 & 30 \\ 2200 & 40 \\ 2200 & 40 \\ 1700 & 30 \\ 3800 & 50 \\ 1300 & 20 \\ M & 60 \\ -500 & 60 \\ 3500 & 70 \\ 1800 & 30 \\ -500 & 60 \\ -400 & 50 \\ 3900 & 70 \\ 3800 & 60 \\ 2600 & 50 \\ 7300 & 70 \\ 1500 & 20 \\ -400 & 50 \\ 2000 & 30 \\ 3000 & 50 \\ 2100 & 40 \\ -500 & 50 \\ 1200 & 20 \\ 2600 & 30 \\ 8100 & 70 \\ 4800 & 80 \\ & \end{array}$




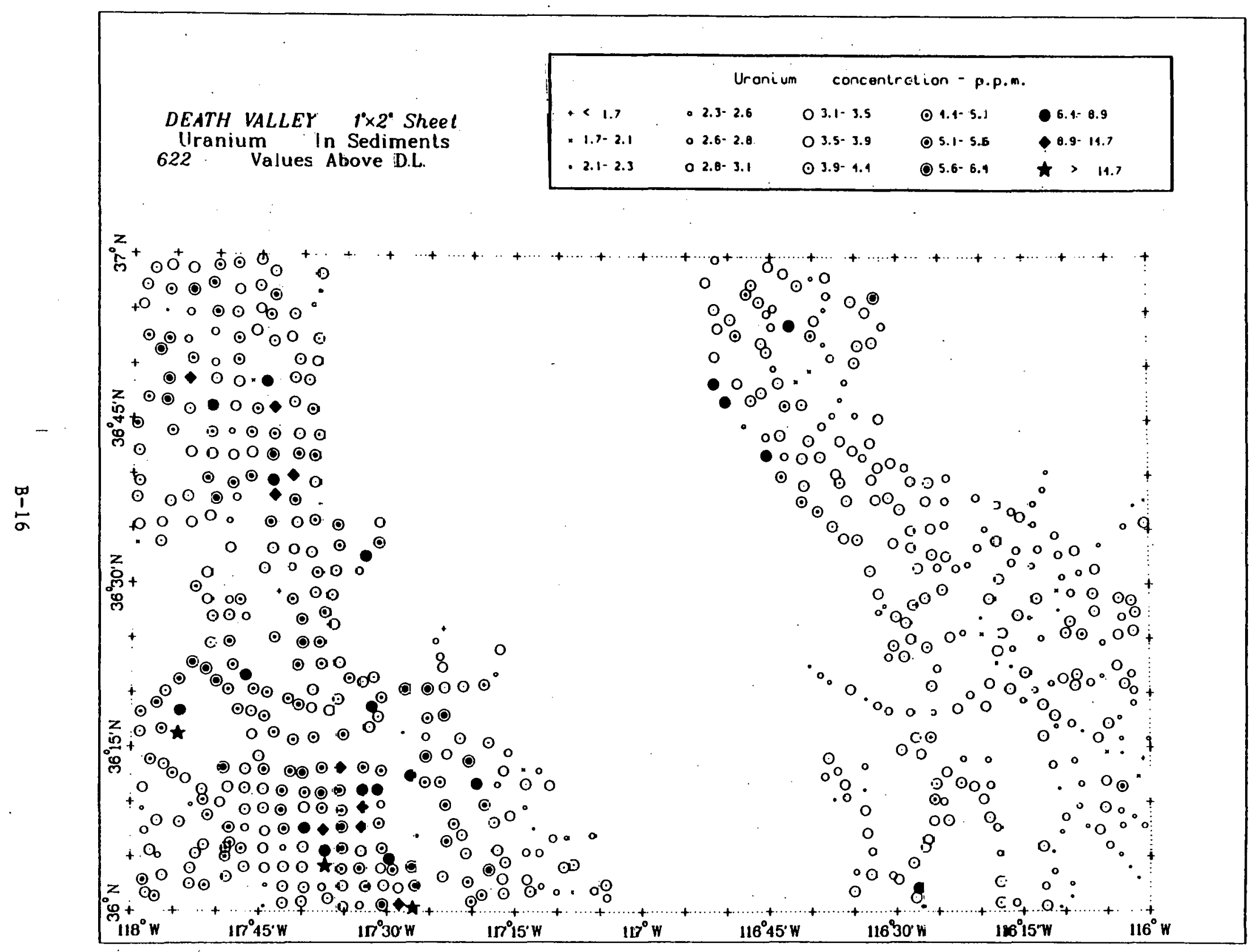

FIGURE B-1. Areal Distribution of Uranium Concentrations in Stream Sediment 


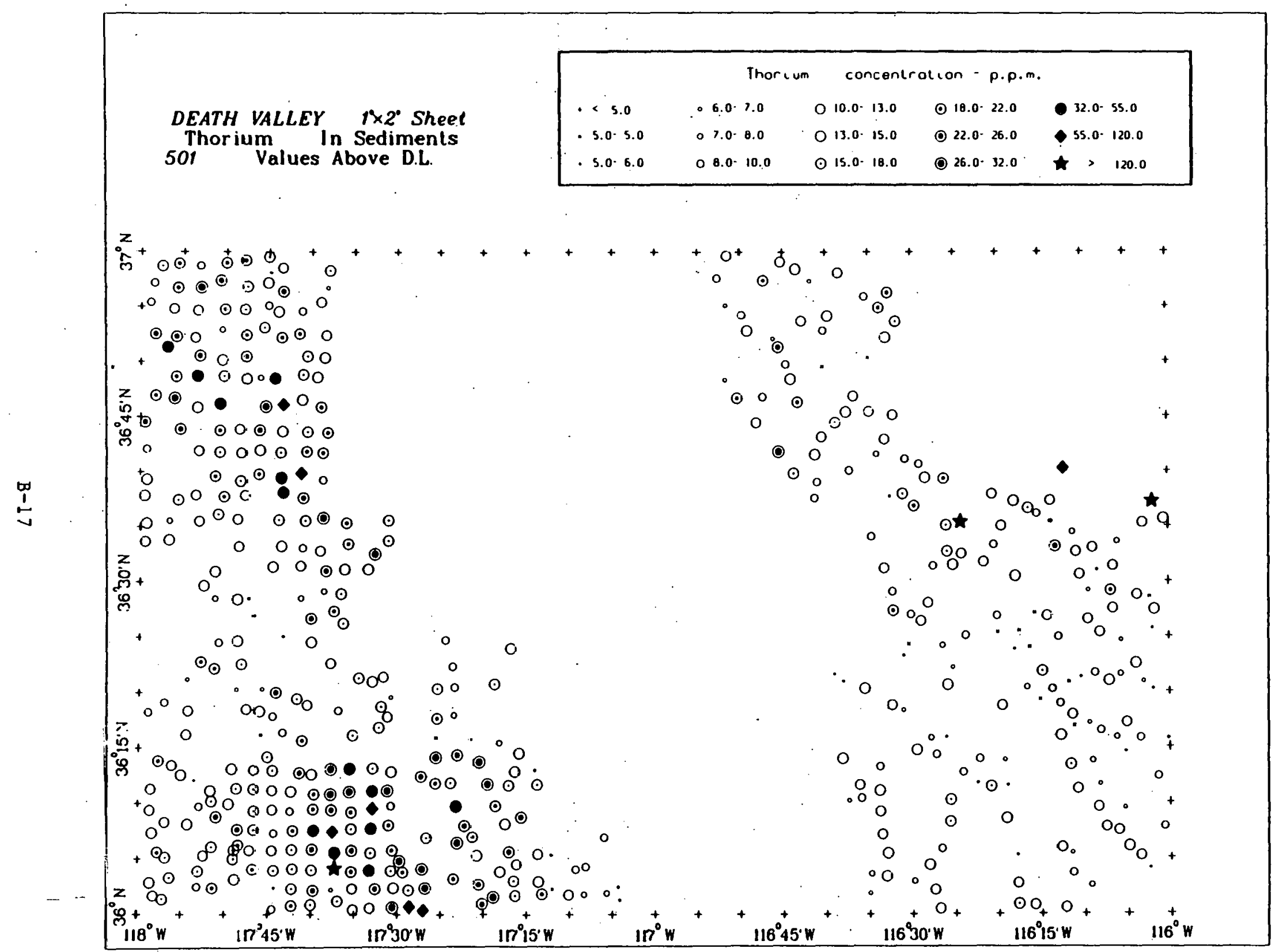

FIGURE B-2. Areal Distribution of Thorium Concentrations in Stream Sediment 


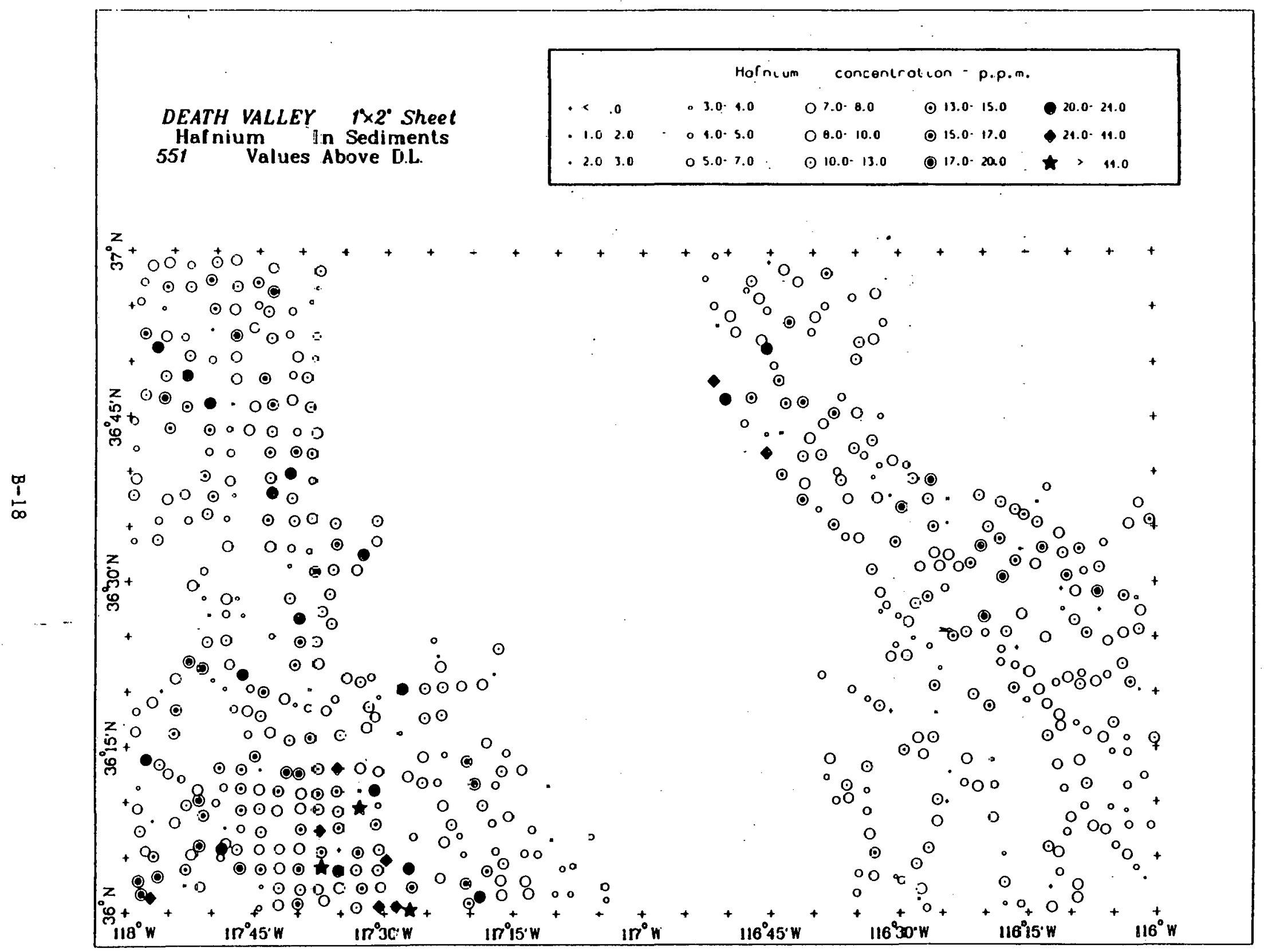

FIGURE 3-3. Areal Distribution of Hafnium Concentrations in Stream Sediment 


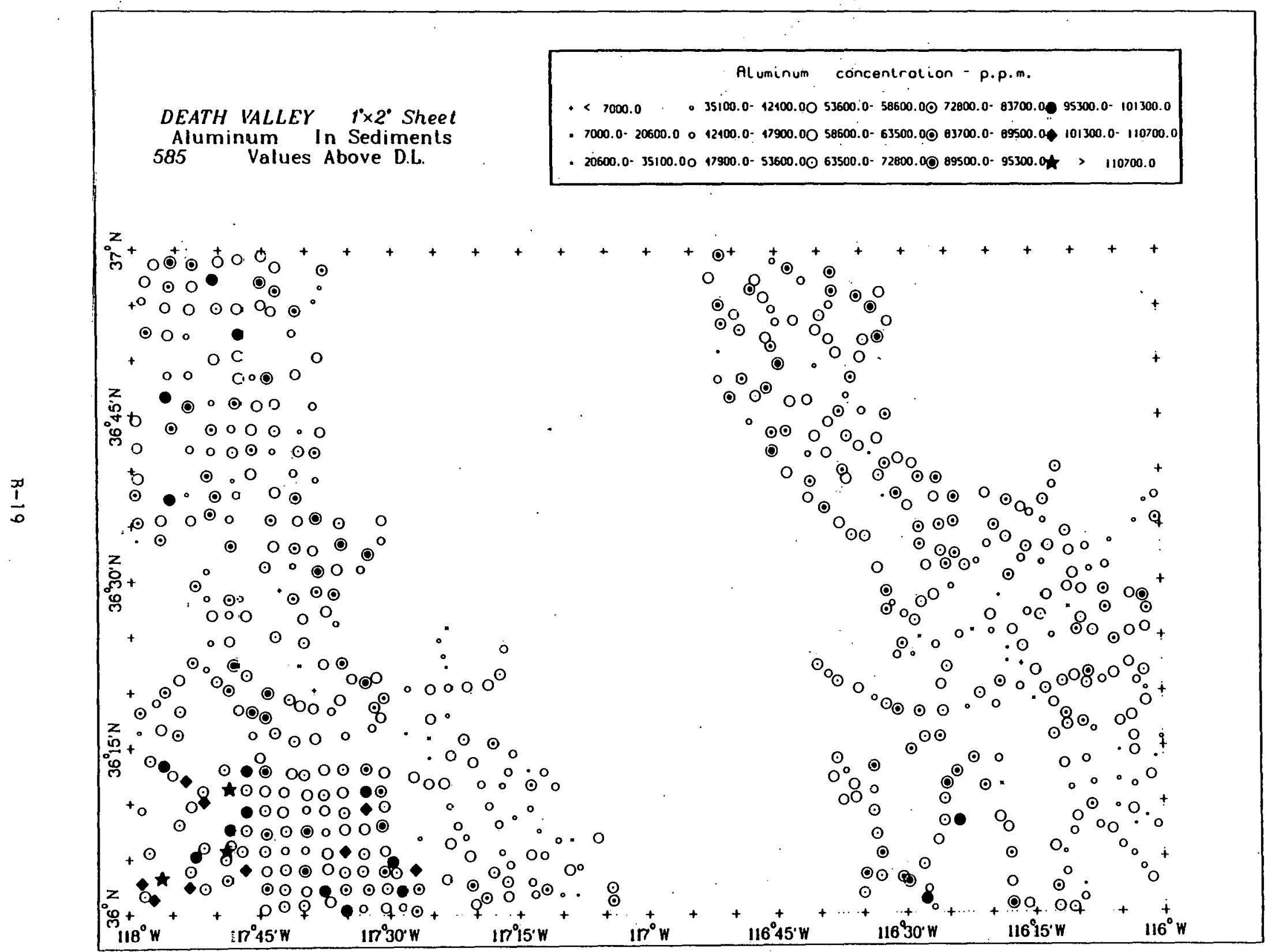

FIGURE B-4. Areal Distribution of Aluminum Concentrations in Stream Sediment 


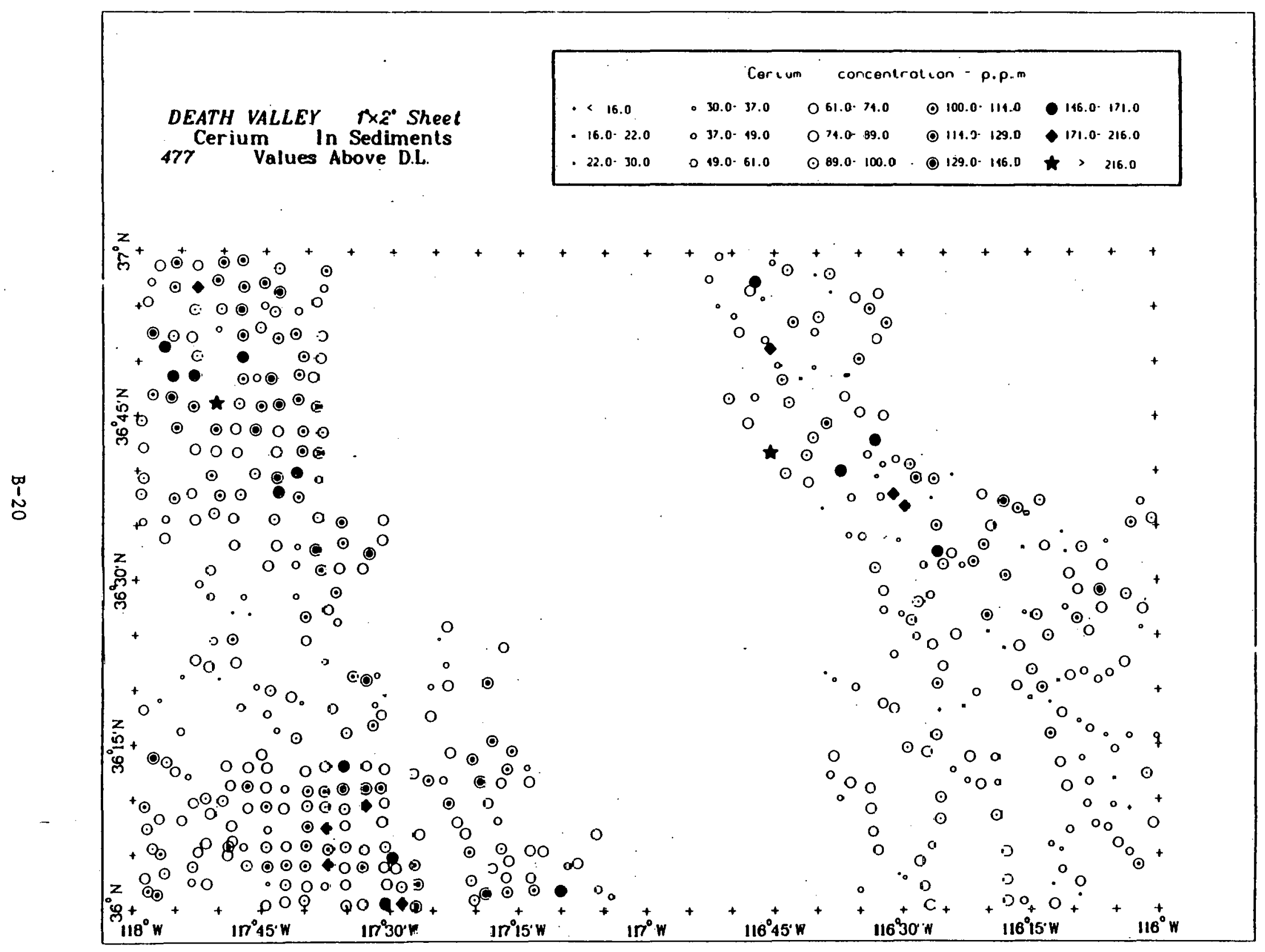

FIGURE B-5. Areal Distribution of Cerium Concentrations in Strean Sediment 


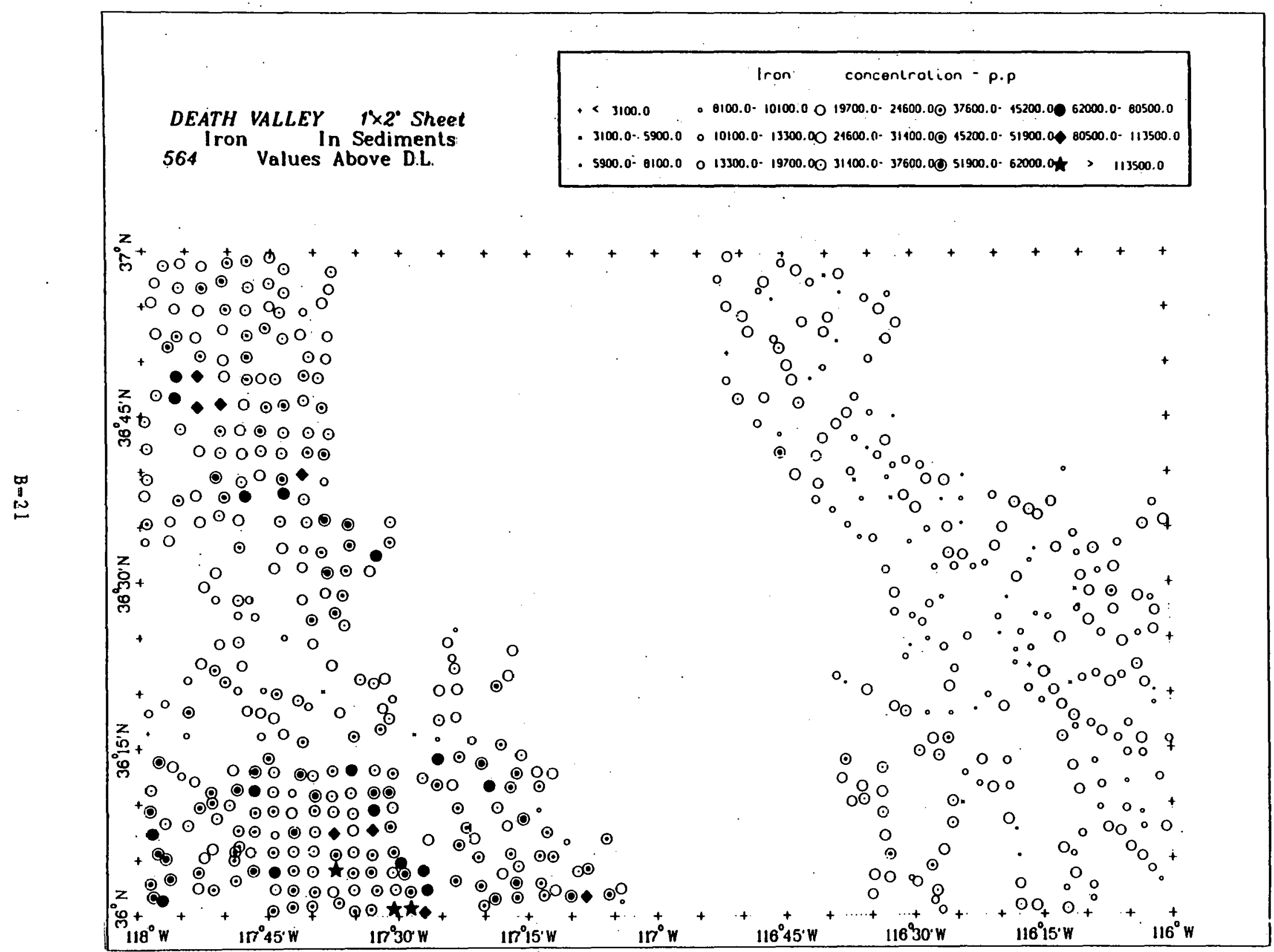

FIGURE B-6. Areal Distribution of Iron Concentrations in Stream Sediment 


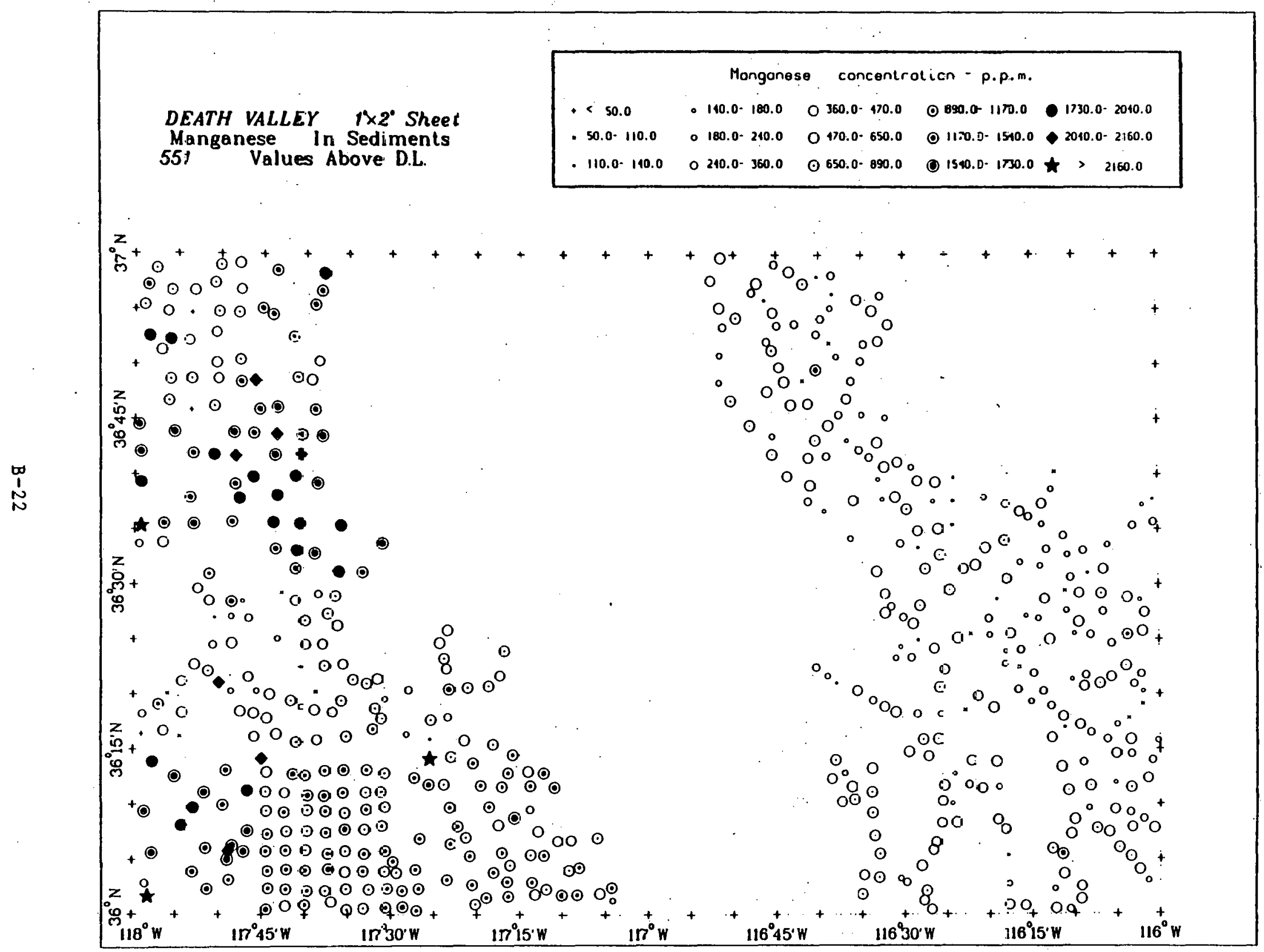

FIGURE B-7. Areal Iistribution of Manganese Concentrations in Stream Sediment 


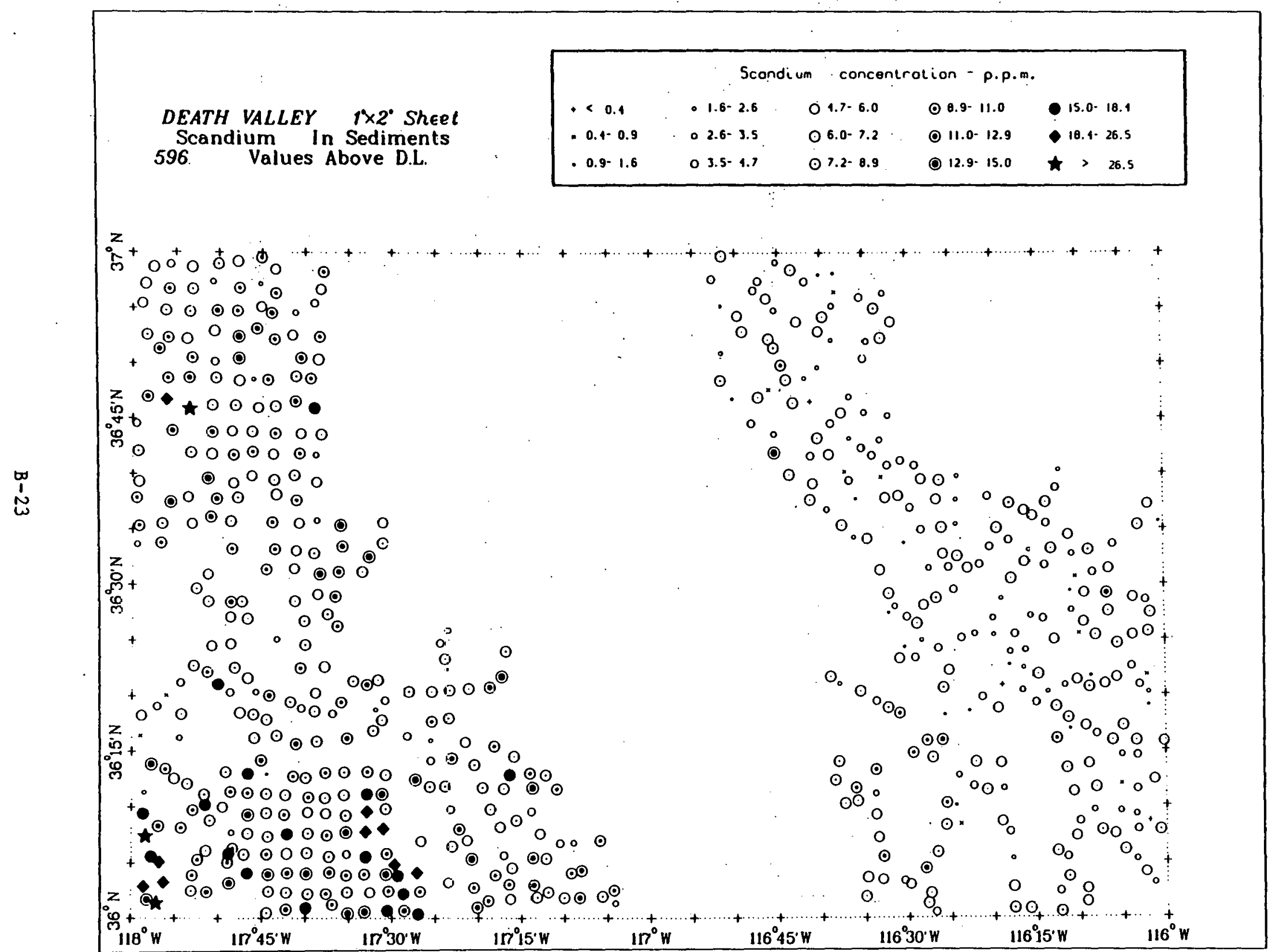

FIGURE B-8. Areal Distribution of Scandfum Concentrations in Stream Sedinent 


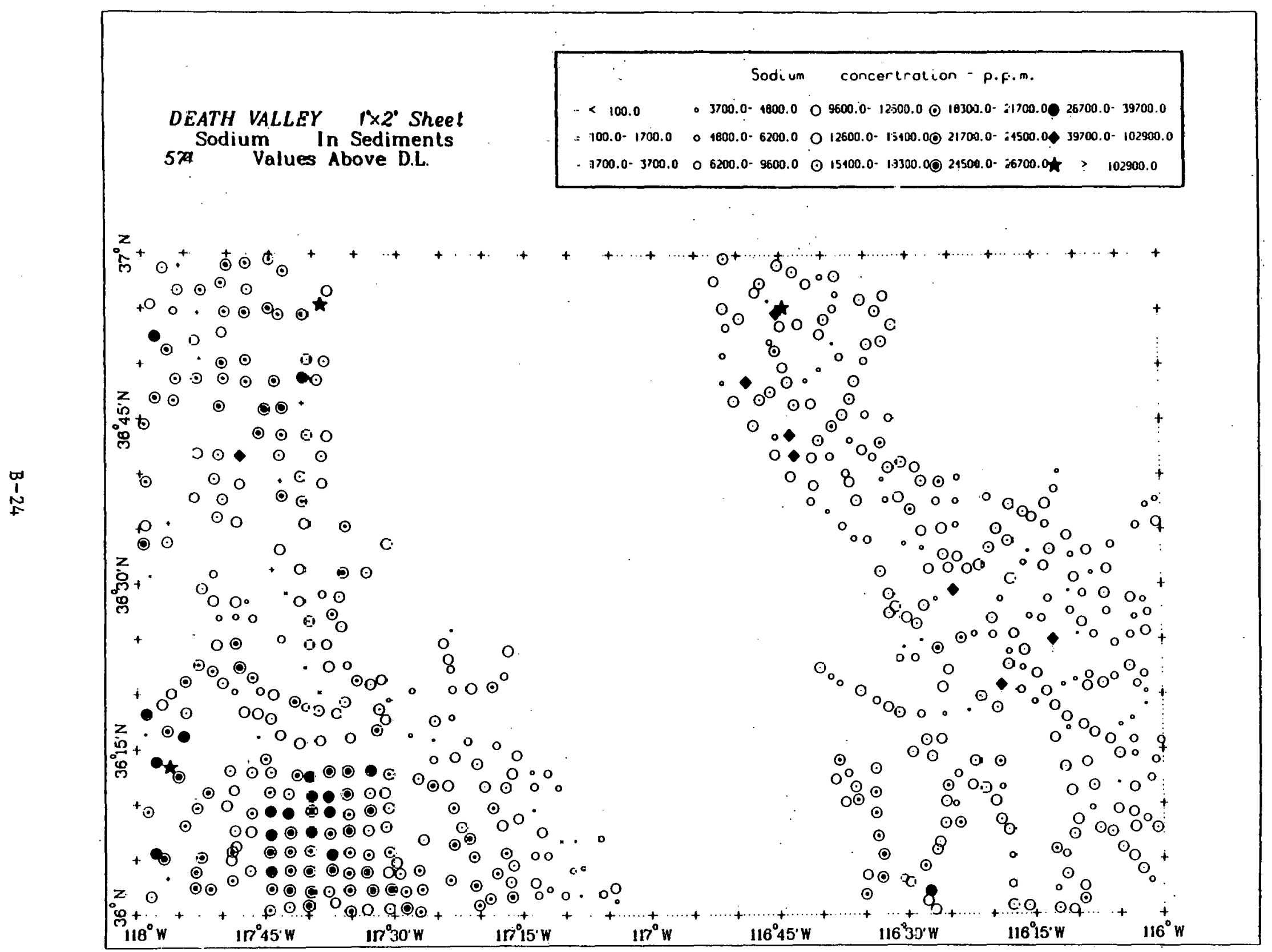

FIGURE B-9. Areal Distribution of Sodium Concentrations in Stream Sediment 


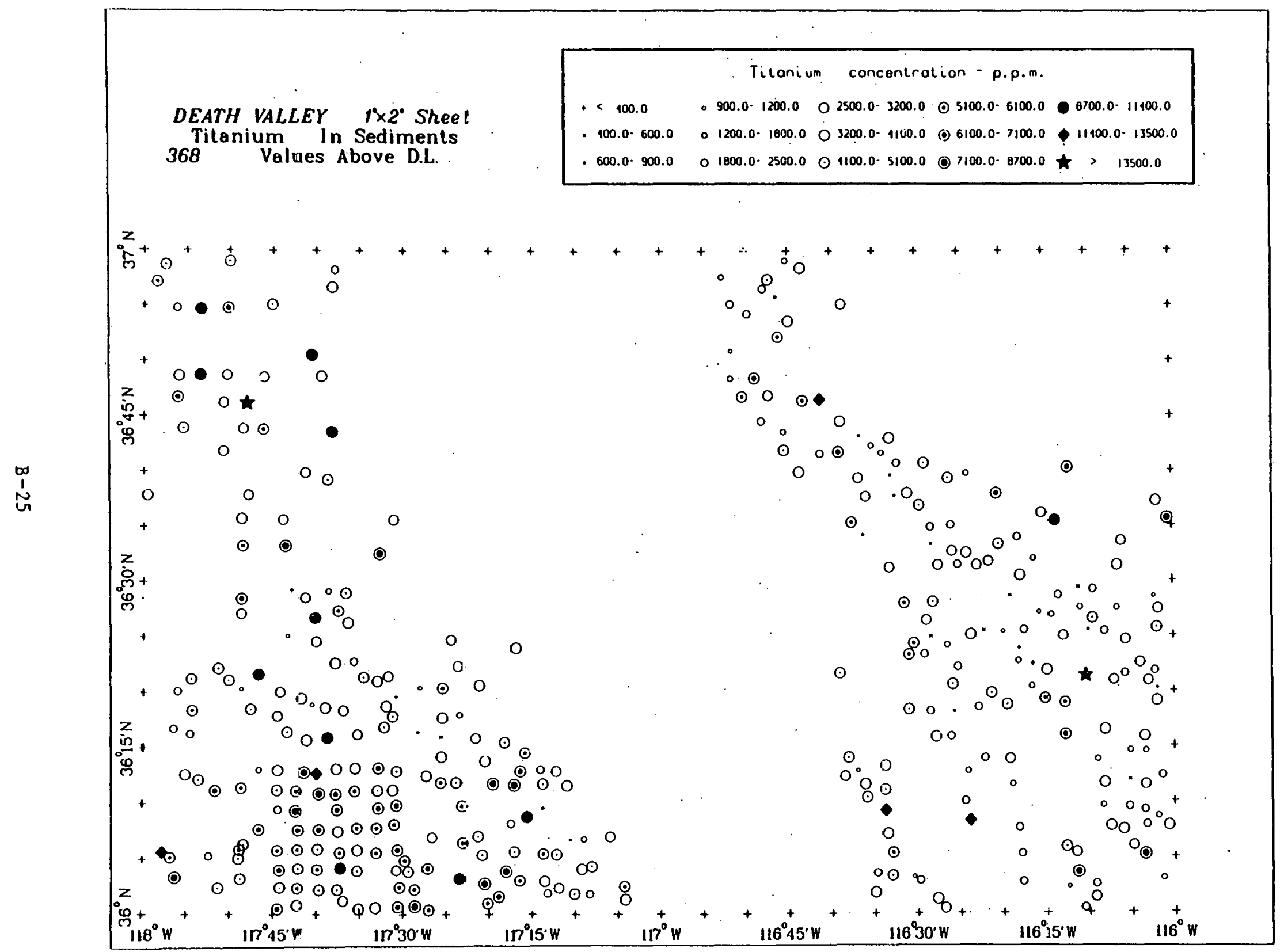

FIGURE B-10. Areal Distribution of Titanium Concentrations in Stream Sediment 


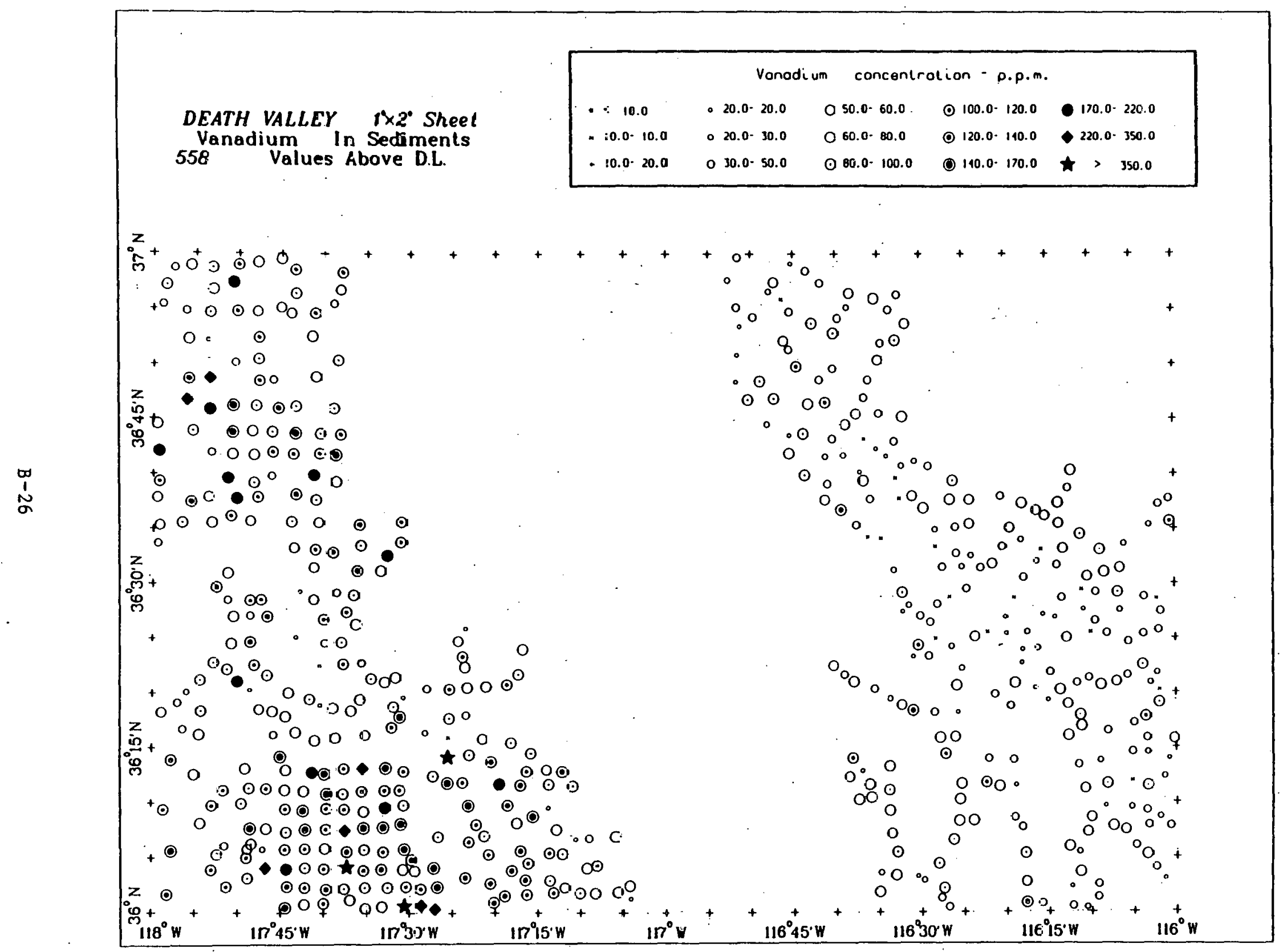

FIGURE :-11. Areal Distributior of Vanadium Concentrations in Stream Sediment 


\section{ABSTRACT}

This document provides a detafled description of Data Reports of the western quadrangles that have been prepared by Savannah River Laboratory (SRL) personnel for the National Uranlum Resource Evaluation. (NURE) program. The Guide includes descriptions of (1) sample collection and field measurements; (2) format, abbreviations, and codes used in data tables; (3) graphical presentation and maps; and (4) quality assurance programs for sample collection and analysis.

\section{CONTENTS}

Introduction $\mathrm{C}-3$

Sample Collection and Field Measurements : C-3

Data. Presentation $\cdot C-5$

I. Columnar Entries for Ground Water Data $C-5$

II. Columnar Entries for Supplementary Ground Water Data $\mathrm{C}-11$

III. Columnar Entries for Sediment Data C-13

IV. Columnar Entries for Supplementary Sediment Data C-14

V. Graphical Data and Maps $\mathrm{C}-17$

Quality Assurance for Sample Collection C-17

References $\quad C-20$ 
C-1 SRI Field Data Form C-4

C-2 Print Modes for Ground Water Sampling Site Identifiers C-6

C-3 Print Modes for Surface Sampling Site Identification C-6

\section{LIST OF TABLES}

C-1. State Codes Used in DOE Identification Number ' $C-8$

C-2 Type Codes Used in DOE Identification Number C-9

C-3 Statistical Distribution Symbols for Areal Maps C-18 


\section{INTRODUCTION}

This document provides a detailed description of Data Reports of the western quadrangles that have been prepared by Savannah River Laboratory (SRL) personnel for the National Uranium Resource Evaluation (NURE) Program. The format described herein is that established for Data Reports in mid-1978. "The descriptions of. tables and figures are general enough to be applied to future Data Reports. However, some minor changes in format may be made as the program progresses.

SRL participation in the NURE Program is summarized in NURESRL progress reports (SRL-138).

\section{SAMPLE COLLECTION AND FIELD MEASUREMENTS}

Sampling personnel were trained by SRL staff members according to procedures in published SRL documents. In the western quadrangles, the principal document was the Training Manual for Water and Sediment Geochemical Reconnalssance (Price and Jones, 1979).

A minimum of five sediment sub-samples was composited from each stream site. An approximately $400-\mathrm{g}$ sample of sediment passing a 420-micrometer screen (U.S. Std. 40 mesh) was collected at each site.

Dissolved ions in individual water samples were concentrated in the field on portions of ion exchange resin [GJBX-77(77)]. The resin was subsequently analyzed at SRL. Special procedures not included in the training manual were employed in certain areas. For example, ground water samples were collected for analys is of helium.

Figure C-1 illustrates the field form completed at each sample collection site. Entrles are self-explanatory. The training manual (Price and Jones, 1979) describes in detail the equipment and techniques (including criteria for site selection) for collecting samples and for making field measurements.

Nominal density for ground water and stream sampling in rural areas varies from 13 to 25 square kilometers ( 5 to $10 \mathrm{sq} \mathrm{mi}$ ) per site, depending upon the geology of the area. In areas of crystalline rock or few ground water sites, surface sampling is generally denser than ground water sampling. In areas of sedimentary rock, the converse is true. Supplemental samples may be collected at sites of high radioactivity or other locations considered by the sampler to be of relatively high uranium potential. 


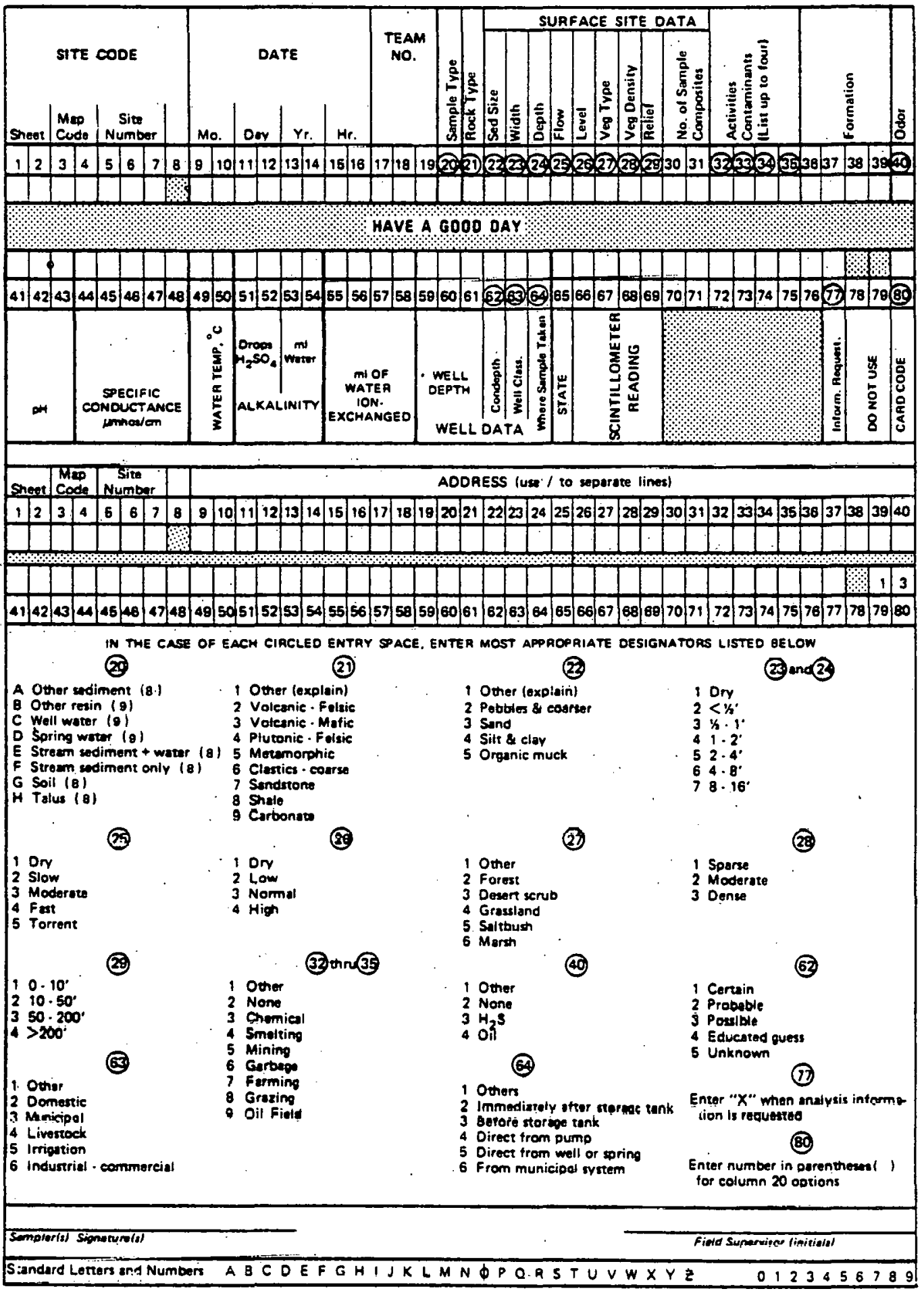

FIGURE, C-1. SRL Field Data Form 
Sampling site locations were marked precisely on compilation maps. The maps were returned to SRL for determination of geographic coordinates. An electronic digitizer (SRP-138) was used to measure and verify latitude and longitude for each site, and then these data were entered into the SRL-NURE data base. These data were recorded to four decimal places, but are considered reliable to only three decimal places.

Plate 2 is a $1: 250,000$ scale overlay of the $1^{\circ} \times 2^{\circ}$ NTMS quadrangle showing ground water sampling sites and SRL identification (ID) numbers. On Plate 2, well and spring sites are distinguished by the use of a "plus" ( + ) for wells and a circle (o) for springs. Print modes for plate 2 are shown in Figure $C-2$. Plate 3 is a $1: 250,000$ scale overlay of the quadrangle showing surface sampling sites and SRL ID numbers. Print modes for Plate 3 are shown on Figure $\mathrm{C}-3$.

\section{DATA PRESENTATION}

In each SRL Data Report, the reconnaissance data are presented in appendices. Coordinates and the most important analytical data and field measurements are listed in full-size tables. Areal distributions of these measurements are also given in fullsize figures. Other field and analytical data are given in tables on microfiche only. Statistical summaries for each element are given in figures on microfiche.

Detailed cumulative frequency plots are included in the margins of the $1: 250,000$ scale maps. Individual points are shown for the cumulative frequency plots and values are summed from highest to lowest for plots on the maps. These cumulative frequency plots also display the relationship between cumulative frequency and standard deviation and cover the complete range of samples.

The following section presents a brief explanation of the columnar entries for tables and descriptions of histograms, cumulative frequency plots and areal symbol plots in the Appendices and on microfiche.

\section{Columnar Entries for Ground Water Data}

The data for ground water normally will be presented in Table A-l of Appendix A. 


\begin{tabular}{|c|}
$\begin{array}{c}\text { Print Modes } \\
\text { for } \\
\text { WELLS }\end{array}$ \\
\hline NCAS +558 \\
+ NCAS 558 \\
NCAS $558+$ \\
NCAS 558 \\
+ \\
+ \\
NCAS 558 \\
NCAS \\
+ \\
558 \\
\hline (Site LoCotion) \\
\hline
\end{tabular}

\begin{tabular}{|c|}
\hline $\begin{array}{c}\text { Print Modes } \\
\text { for } \\
\text { SPRINGS }\end{array}$ \\
\hline NCAS O 558 \\
O NCAS 558 \\
NCAS 5580 \\
NCAS 558 \\
0 \\
0 \\
NCAS 558 \\
NCAS \\
0 \\
558 \\
\hline O(Site LOCOtion) \\
\hline
\end{tabular}

FIGURE C-2. Print Modes for Ground Water Sampling Site Identifiers

\begin{tabular}{c} 
Print Modes \\
for \\
SURFACE SITES \\
\hline NCAS + 050 \\
+ NCAS 0.58 \\
NCAS $058+$ \\
NCAS 058 \\
+ \\
+ \\
NCAS O58 \\
NCAS \\
+ \\
OSB \\
\hline+ (Site LOCOtion) \\
\hline
\end{tabular}

FIGURE C-3. Print Modes for Surface Sampling Site Identification 


\section{SRL Identification Number}

Each SRL identification (ID) site code consists of seven characters. The first two characters give the $1^{\circ} \times 2^{\circ}$ NTMS quadrangle from which the sample was collected. Map codes are entered as Characters 3 and 4; these represent 15-minute quadrangles. Codes used are listed in Figure 2 of each report. Sites are numbered sequentially within each map unlt (Characters 5,6 , and 7 ). Numbers begin with 501 in each map unit for ground water sites and generally are consecutive. Columns 8 and 9 represent the sample analyzed.

\section{DOE Identification Number}

Each sample is assigned a DOE ID number. The number consists of 28 characters as follows:

1-2 State (See Table $(-1$ )

4-10 Latitude of site

12-19 Longitude of site

21. Laboratory code $(4=S R L)$

23-24. Sample type (See Table C-2)

26-28 Replication code. Generally only original samples $(-000)$ are reported in the Data Releases.

$\mathrm{pH}$

Normally, $\mathrm{pH}$ will be in the range of 4.0 to 9.5. Values far outside this range may suggest instrument malfunction or pollution. Missing data are indicated by " $M$ ".

\section{COND}

Conductivity, measured in micromhos $/ \mathrm{cm}$.

\section{ARMXD}

Alkalinity as milliequivalents of sulfuric acid required per liter of sample (meq/L) to titrate to a pH of approximately 4.5 (bromcresol-green/methyl-red end-point). 
TABLE C-1

Stace Codes Used In DOE Identification Number

\begin{tabular}{|c|c|c|c|}
\hline State & Code & State & Code \\
\hline Alabama & 01 & Nevada & 32 \\
\hline Arizona & 04 & New Hampshire & 33 \\
\hline Arkansas & 05 & New Jersey & 34 \\
\hline California & 06 & New York & 36 \\
\hline Connecticut & 09 & North Carolina & 37 \\
\hline Delaware & 10 & Ohio & 39 \\
\hline District of Columbia & 11 & Oklahoma & 40 \\
\hline Florida & 12 & Oregon & 41 \\
\hline Georgia & 13 & Pennsylvania & 42 \\
\hline Idaho & 16 & Rhode Island & 44 \\
\hline Illinols & 17 & South Carolina & 45 \\
\hline Indiana & 18 & Tennessee & 47 \\
\hline Kentucky & 21 & Texas & 48 \\
\hline Louisiana & 22 & Utah & 49 \\
\hline Maine & 23 & Vermont & 50 \\
\hline Maryland & 24 & Virginia & 51 \\
\hline Massachusetts & 25 & Washington & 53 \\
\hline Michigan & 26 & West Virginia & 54 \\
\hline Mississippi & 28 & & \\
\hline Missouri & 29 & & \\
\hline
\end{tabular}


TABLE C-2

Type Codes Used in DOE Sample Identification Number*

Digit Sample Type

50 Stream sediment from flowing stream, sieved $<149 \mathrm{\mu m}$ and dried $\leq 110^{\circ} \mathrm{C}$

51 Stream water, filtered through $\leq 0.8 \mathrm{um}$ filter at the site

52 Well water, filcered through $\leq 0.8 \mathrm{um}$ filter at the site

53. Spring water, filtered through $<0.8 \mu \mathrm{m}$ filter at the site

54 Lake water, filtered through $\leq 0.8$. um filter at the site

55 Lake sediment

$56 \quad$ Glacial till

57 Peat

$58 \quad \therefore \quad$ Soil ; sieved $>149, \mathrm{~mm}$ and $<1000 \mathrm{um}$

59 Soil, sieved $<149 \mu \mathrm{m}$

60 Stream sediment from dry stream, sieved $>149 \mu \mathrm{m}$ and $<1000 \nu \mathrm{m}$, and $\mathrm{dried}<110^{\circ} \mathrm{C}$

61 Stream sediment from dry stream, seived $<149 u m$ and dried $<110^{\circ} \mathrm{C}$.

62 Talus

63 Volcanic neck

$64 \quad$ Playa sediment

65 Hot springs, sinter

66-69 Spare numbers**

\footnotetext{
* The 28-character DOE-GJO identification number for NURE samples contains two digits to denote sample type. The digits 50 through 69 have been set aside for SRL use.

th's To be noted in individual reports as needed.
} 
DPTE

Depth of the well in feet, if known. These data are generally provided by the householder. An estimate of the confidence in this number is given in the microfiche Table A-2. "U" indicates that the well depth is not known. Springs are coded as having a depth of 0 feet.

$\mathrm{U}$

Uranium in ground water is determined by delayed neutron counting after concentrating the uranium on ion exchange resin. $U$ is reported in parts yer billion (ppb).

Values have been rounded to appropriate significant figuree. Values for uranium afe reported for all samples analyzed; however, analyses $<0.040 \mathrm{ppb}$ exhibit a high coefficient of variation. Missing data are indicated by " $M$ ". Where all analytical data for a sample are missing, samples will generally be analyzed and reported in a supplementary report.

\section{$\mathrm{U} /$ COND}

Uranium concentration in ppb multiplied by 1.000 and divided by conductivity is listed in this column. This value gives ail approximatiun of the ratio of uranium to total dissolved solids.

\section{Helium}

Helium ( $4 \mathrm{He}$ ) is determined for selected quadrangles using a specially developed mass spectrometric procedure (SRP-138b). When available, helium values are reported in standard cubic centimeters of helium per 1000 liters of air ( $\mathrm{cm}^{3} \mathrm{He} / 1000 \mathrm{~L}$, i.e., ppm by volume). The measurement is made on a $2-\mathrm{cm}^{3}$ air-gap above a $300-\mathrm{cm}^{3}$ water sample. This method introduces a nearly constant $5.2 \mathrm{ppm}$ helium background from air; thus, all samples analyzed are above detection limit.

\section{Uther Rey Elemental Analyses}

Other elements analyzed were determined by neutron activation analysis (unless otherwise noted) and are listed alphabetically, Concentrations are reported in ppo. Values below detection limit are indicated by a minus $(-)$. For example, -3 means that the sample contains less than $3 \mathrm{ppb}$ of that element. If background is so high that an accurate estimate of the minimum detection limit 
is not available, a period (.) is used to indicate not only that the element was not detected, but that the detection limit is unusually high for that sample. Missing data are indicated by "M". Where all analytical data for a sample are missing, samples will generally be analyzed and reported in a supplementary report.

II. Columnar Entries for Supplementary Ground Water Data.

These data are presented on microfiche only.

SRL Identification Number

Same as in Table A-l.

Supplementary Elemental Analyses

Same format as Table A-1.

\section{SAMPDATE}

The date of sampling (month/day/year). For example, $7 / 15 / 77$ is July $1.5,1977$.

\section{TEAM}

This code identifies. the personnel who performed the sampling and is used by SRL for quality assurance monitoring.

\section{ROCKTYPE}

Th1s cude idetilifies the predominant rock type present in immediate vicinity of the sample site. The types listed are:

1 Other

2 Volcanic - Felsic

3 Volcanic - Mafic

4 Plutonic - Felsic

5 Metamorphic

6 Clastic-coarse

7 Sandstone

8 Shale

9 Carbonate

0 Unconsolidated valley fill

\section{CONTAMN}

The activities/contaminants columns indicate those nearby activities which may influence the analytical results. It is a 
very important entry, chosen from the list of numerical designators shown. The major activity and/or contamination is always listed under CONTAMN4. A second activity, if considered important, is listed under CONTAMN3, etc.

$\begin{array}{lllll}\text { CONTAMN1 } & 1 & \text { Other } & 6 & \text { Garbage } \\ \text { CONTAMN2 } & 2 & \text { None } & 7 & \text { Farming } \\ \text { CONTAMN3 } & 3 & \text { Chemical } & 8 & \text { Grazing } \\ \text { CONTAMN4 } & 4 & \text { Smelting } & 9 & \text { Oil field } \\ & 5 & \text { Mining } & & \end{array}$

\section{FORM}

This code indicates the geologic formation surrounding the sampling site. The first letter and the next three consonants in the formation name are entered. Similarly the age is entered if the uame of the formation is unknown. If nelther formation or age are known, "UNKN" is entered.

\section{ODOR}

Odors in well water are noted. The entries in this column and their meanings are:

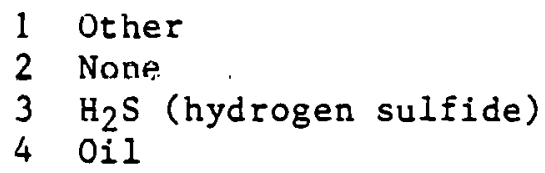

\section{TEMP}

The water temperature at the time of sampling is recorded in this column. The water temperature is recorded in degrees Celsius $\left({ }^{\circ} \mathrm{C}\right)$ to the nearest whole degree.

\section{DEPTHCON}

Confidence in the values of well depths is listed in this eolumn. The possible entries are:

1 Certain

2 Probable

3 Possible

4 Educated Guess

5 Unknown 
Any site with "U" listed in DPTH should have "5" listed for DEPTHCON.

\section{WELLOC}

The positions at which samples are taken are listed in this column. The positions listed are relative positions in plumbing systems. The entries and their meanings are:

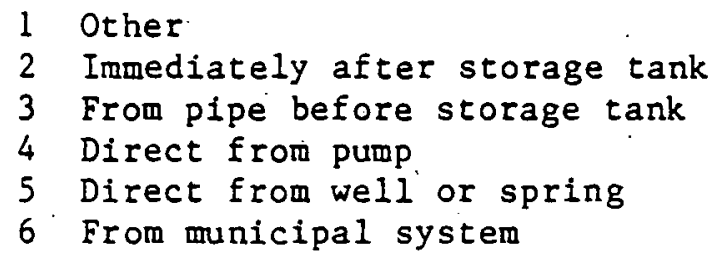

\section{WELCLASS}

Sampled wells are classified by use. The classes of wells recognized here are:
1. Other
4 Livestock
2 Domestic
3 Municipal
5 Irrigation
6 Industrial - commercial

\section{SCINT}

A scintillometer reading in counts per second is recorded at the sampling site.

\section{Columnar Entries for Sediment Data \\ Sediment data (and accompanying water quality measurements) will normally be presented in Tables $B-1$ (full-sized tables) and B-2 (microfiche tables).}

\section{SRI Identification Number}

Each SRL identification (ID) site code consists of seven characters. The first two characters give the $1^{\circ} \times 2^{\circ}$ NTMS quadrangle in which the sample was collected. Map codes are entered as Characters 3 and 4; these represent 15-minute quadrangles. Codes used are listed in Figure 2 of each report. Sites are numbered sequentially within each map unit (Characters 5,6 , and 7 ). Numbers begin with 001 in each map unit for stream sites and are 
generally consecutive. Columns 8 and 9 represent the sample analyzed. In most reports, the $\mathrm{Sl}$ fraction [finer than 149 micrometers (U.S. Std. 100 mesh)] was analyzed. SO and $S 2$ mean that coarser $(149 \mathrm{um}$ to $1000 \mathrm{um}$ ) or finer (<149 um) fractions, respectively, were analyzed. Specific fractions will be identified in individual reports as necessary.

\section{DOE Identification Number}

Each sample is assigned a 28-Character DOE ID number as described for Table A-1 in Appendix A.

FORM, ODOR, PH; COND, UM/CM; AKMXD, MEQ/L

Same format as Table A-1.

\section{Rey Elemental Analyses}

The first three elements are listed in order of importance; other key elements are listed alphabetically.

Concentrations of each element (in ppm) are determined by neutron activation analysis (unless otherwise noted). Values have been rounded to appropriate significant figures. Note that the elemental (not oxide) concentration is quoted in this table. Values below detection 1 imit are indicated by a minus ( - ). For example, -3 means that the sample contains less than $3 \mathrm{pom}$ of that element. If background limit is not available, a period (.) is ueed to indicate not only that the element was not detected, but that the detection liuil is unusually high for that sample. Missing data are indicated by " $M$ ". Where all analytical data for a sample are missing, samples will generally be analyzed and reported in a supplementary report.

\section{Columnar Entries for Supplementary Sedimant Data}

These data are presented on microfiche only.

SRL Identification Number

Same as in Table $B-1$. 


\section{Supplementary Elemental Analyses}

Same format as Table B-1.

\section{SAMPDATE} is July $15,1979$.

The date of sampling, month/day/year. For example, $7 / 15 / 79$

\section{TEAM}

This code: identifies the personnel who performed the sampling and is used by SRL for quality assurance monitoring.

\section{ROCKTYPE}

This and following columns contain codes describing the sample site characteristics. Rocktype identifies the predominant rock type present in the immediate vicinity of the sample site. The types listed are:

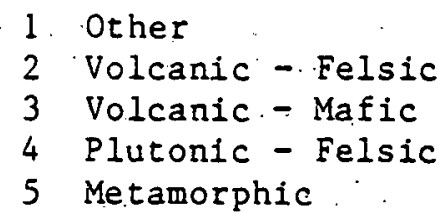

SEDSIZE

This code reflects the nature of the loose sediment material at the sampled site.

\author{
6 Clastic - coarse \\ 7 Sandstone \\ 8 Shale \\ 9 Carbonate \\ 0 . Unconsolidated valley fill
}

1 Other

2 Pebbles and coarser

3 Sand

\section{STMWIDTH AND STMDEPTH}

$\begin{array}{llll}1 & \text { Dry } & 5 & 2 \text { to } 4 \mathrm{ft} \\ 2 & <1 / 2 \mathrm{ft} & 6 & 4 \text { to } 8 \mathrm{ft} \\ 3 & 1 / 2 \text { to } 1 \mathrm{ft} & 7 & 8 \text { to } 16 \mathrm{ft} \\ 4 & 1 \text { to } 2 \mathrm{ft} & & \end{array}$

An estimate of the AVERAGE width and depth of the stream over the 100 to 200 feet of stream length where. the sample was taken. 


$\begin{array}{llll}1 & \text { Dry } & 1 & \text { Dry } \\ 2 & \text { Slow } & 2 & \text { Low } \\ 3 & \text { Moderate } & 3 & \text { Normal } \\ 4 & \text { Fast } & 4 & \text { High } \\ 5 & \text { Torrent } & & \end{array}$

The water description provides an indication of the general condition of the water at the time of sampling. STMFLOW indicates the rate of flow using the listed descriptors at the sampled location [i.c., if a stream 1s sampled in rapids, the 4 (Fast) or 5 (Torrent) may apply; but if the smo etrcam were saüpled above or below the rapids, the 2 (Slow) or 3 (Moderate) descriptors might be more accurate]. STMLEVEL describes the water level relative to its apparent normal level.

\section{VEGTYPE}

1 Other

2 Forest

3 Desert Scrub

4 Grassland

5 Saltbush

6. Marst.

\section{VEGDENS}

\section{Sparse}

2 Moderate

3 Dense

These descriptions reflect the amount and type of plant growth in the immediate area of the sample locatinn. The deneity is a subjective observation made in relation to visibility, eacc of access, etc. 'The type of vegetation reflerts the dominant plant type at or near the sample location.

\section{RELIEF}

$$
\begin{array}{ll}
1 & 0 \mathrm{to} 10 \mathrm{ft} \\
2 & 10 \mathrm{to} 50 \mathrm{ft} \\
3 & 50 \mathrm{to} 200 \mathrm{ft} \\
4 & >200 \mathrm{ft}
\end{array}
$$

Relief is an 1ndicator of local surface expression.

COMPOSIT

COMPOSIT refers to the number of subsamples taken at each site that are composited to give the sieved sample for that site. 


\section{CONTAMN}

The activities/contaminants columns indicate those nearby activities which may influence the analytical results. It is a very important entry, chosen from the list of numerical designators shown. The major activity and/or contamination is always listed under CONTAMN4. A second activity, if considered important, is listed under CONTAMN3, etc.

$\begin{array}{lllll}\text { CONTAMN1 } & 1 & \text { Other } & 6 & \text { Garbage } \\ \text { CONTAMN2 } & 2 & \text { None } & 7 & \text { Farming } \\ \text { CONTAMN3 } & 3 & \text { Chemical } & 8 & \text { Grazing } \\ \text { CONTAMN4 } & 4 & \text { Smelting } & 9 & \text { Oil field } \\ & 5 & \text { Mining } & & \end{array}$

\section{WATERTEM}

The water temperature, taken at the time of sampling, is coded under WATERTEM. : The water temperature is recorded in degrees Celsius $\left({ }^{\circ} \mathrm{C}\right)$ to the nearest whole degree.

\section{Graphical Data and Maps}

Areal distributions ("symbol plots") of all measurements in Tables $A-1$ and $B-1$ are presented in hard copy. Graphical summaries of elemental data in. Tables $A-2$ and $B-2$ are on microfiche only. Histograms and cumulative frequency plots are given on microfiche. The symbols for the areal distribution plots are derived from the statistical distribution of the measurements within the quadrangle being reported (Table $\mathrm{C}-3$ ). Symbols are based upon statistical distribution rather than absolute values to. permit convenient comparison of elements with widely differing concentration ranges.

\section{QUALITY ASSURANCE FOR SAMPLE COLLECTION}

Three to ten percent of the sampled sites were routinely checked by SRL personnel or by a separate subcontractor to assure that the reported field locations were accurate. Based on these quality assurance checks, the vast majority of sampled sites were judged to be located as accurately as they could be plotted on available maps. Most sites that were mapped incorrectly were within 300 meters of their correct locations. Details of mapping errors are given in each Data Report in the section on Factors Affecting the Data. Thus, the goals of a regional reconnaissance have not been compromised by mapping errors. Details of the quality assurance program are given in NURE-SRL progress reports (SRL-138). 
TABLE C-3

Statistical Distribution Symbols for Areal Maps

\begin{tabular}{|c|c|c|}
\hline Symbol & $\begin{array}{l}\text { Percentile } \\
\text { Range }\end{array}$ & $\begin{array}{l}\text { Standard } \\
\text { Deviation } \\
\text { Above Mean }\end{array}$ \\
\hline & $>99.5$ & $>2.6$ \\
\hline & 98.6 to 99.5 & 2.2 to 2.6 \\
\hline & 96.4 to 98.6 & 1.8 to 2.2 \\
\hline (0) & 91.9 to 96.4 & 1.4 to 1.8 \\
\hline ) & 84.1 to 91.9 & 1.0 to 1.4 \\
\hline ) & 72.6 to 84.1 & 0.6 to 1.0 \\
\hline & 57.9 to 72.6 & 0.2 to 0.6 \\
\hline & 42.1 to 57.9 & -0.2 to 0.2 \\
\hline & 27.4 to 42.1 & -0.6 to -0.2 \\
\hline 0 & 15.9 to 27.4 & -1.0 to -0.6 \\
\hline 0 & 8.1 to 15.9 & -1.4 to -1.0 \\
\hline o & 3.6 to 8.1 & -1.8 to -1.4 \\
\hline - & 1.4 to 3.6 & -2.2 to -1.8 \\
\hline$x$ & $<1.4$ & $<-2.2$ \\
\hline+ & - & $\begin{array}{l}\text { helow derection } \\
\text { limit }\end{array}$ \\
\hline
\end{tabular}

$\dot{a}$. Signs are reversed relative to cumulative frequency plots. In the cumulative frequency plots, values are accumulated from the largest to the smallest value to onsure that the largest value is plotted. "Percentile" assumes accumulation from the smallest to the largest value. 
Field measurements were checked for approximately $2 \%$ of the sites. Where important variations occurred, the sampling subcontractor was required to repeat measurements for the area in question. Only the corrected values are reported. Questionable data that could not be corrected are discussed in individual reports or omitted, depending upon the severity of the potential error. 
GJBX-77(77), Proceedings of Symposium on Hydrogeochemical and Stream Sediment Reconnaissance for Uranium in the United States, Grand Junction, Colorado, March 16 and 17, 1977: DOE-GJO Document No. GJBX-77(77).*

Price, V., aud Jones, P. Lo, 1979, Training Manual for Wastes and Sediment Geochemical Reconnalssance: SRL Document DPST-79-219, E. I. du Pont de Nemours \& Co., Inc., Savannah River Laboratory, Aiken, South Carolina. DOE-GJO Document No. GJBX-XX(79).*

SRL-138, NURE-SRL progress reports:

1. Savannah RIver Laboratory Quarterly Reports; Hydrogeochemical and Stream Sediment Reconnąissance - Eastern United States; National Uranium Resource Evaluation Program: E. I. du Pont de Nemours \& Co., Inc., Savannah River Laboratory, Aiken, South Carolina.

No. Quarter

$\begin{array}{ll}\text { a } & \text { January-March } 1975 \\ \text { b } & \text { April-June } 1975 \\ \text { c } & \text { July-Septcmber } 1975 \\ \text { d } & \text { October-December } 1975 \\ \text { e } & \text { January-March } 1976 \\ \text { f } & \text { April-June } 1976 \\ \text { g } & \text { July-September } 1976 \\ \text { h } & \text { October-December } 1976 \\ \text { i } & \text { January-March } 1977 \\ \text { j } & \text { April-June } 1977 \\ \text { k } & \text { July-Sprtember } 1977 \\ \text { l } & \text { October-December } 1977 \\ \text { m } & \text { January-March } 1978\end{array}$

SRL Document No.

$$
\begin{aligned}
& \text { DPST }-75-138-1 \\
& \text { DPST }-75-138-2 \\
& \text { DPST } 75-138-3 \\
& \text { DPST } 75-138=4 \\
& \text { DPST } 76-138-1 \\
& \text { DPST } 76-138-2 \\
& \text { DPST }-76-138-3 \\
& \text { DPST }-76-138-4 \\
& \text { DPST } 77-138-1 \\
& \text { DPST }-77-138-2 \\
& \text { DEST } 77-138=3 \\
& \text { DPST } 77-138-4 \\
& \text { DPST }-78-138-1
\end{aligned}
$$

DOE-GJO

Document No.*

$$
\begin{aligned}
& \text { GJBX-5(76) } \\
& \text { GJBX-6(76) } \\
& \text { GJBX-7(76) } \\
& \text { GJBX } 0(76) \\
& \text { GJBX-17(76) } \\
& \text { GJBX-27(76) } \\
& \text { GJBX-63(76) } \\
& \text { GJBX-6(77) } \\
& \text { GJBX-35(77) } \\
& \text { GJBX-55(77) } \\
& \text { GJBX-90(77) } \\
& \text { GJBX-37(78) } \\
& \text { GJBX-66(78) }
\end{aligned}
$$

\footnotetext{
* DOE-GJO reports are available on microfiche from the Grand Junction office, DOE, for $\$ 6.00$. Prepaid orders should be sent to: Bendix Field Engineering Corporation, Technical Library, P.0. Box 1569, Grand Junction, Colorado 81501 . Checks or money orders should be made out to Bendix Field Engineering Corporation, the operating contractor for DOE's Grand Junction office.
} 
2. Savannah River Laboratory Semiannual Reports; Hydrogeochemical and Stream Sediment Reconnaissance. Eastern United States; National Uranium Resource Evaluation Program:

E. I. du Pont de Nemours \& Co., Inc., Savannah River Laboratory, Aiken, South Carolina.

No. Period

a April-September 1978
DOE-GJO

SRL Document No. Document No.*

DPST $-78-138-2$

GJBX-13(79)

3. Savannah River Laboratory Semiannual Reports; Hydrogeochemical and Stream Sediment Reconnaissance; National Uranium Resource Evaluation Program: "E. I. du Pont de Nemours \& Co., Inc., Savannah River Laboratory, Aiken; South Carolina.

DOE-GJO

No. Period $\quad \therefore$ SRL Document No. " Document No.*

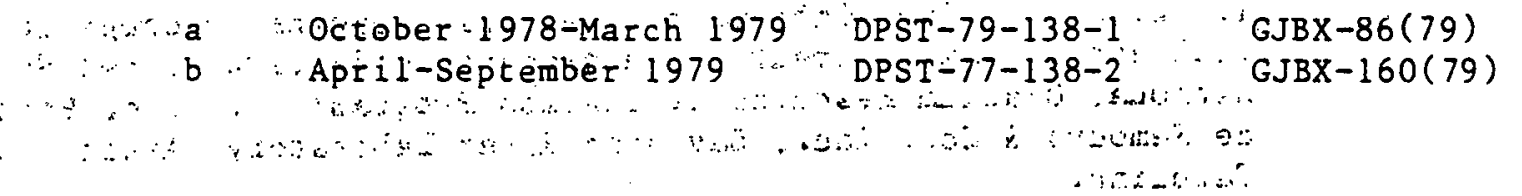

*-DOE-GJO reports are available on microfiche from the Grand Junction Office, DOE, for $\$ 6.00$. Prepaid orders should be sent to: Bendix Field Englneeriug Corporation, Technical Library, P. O. Box 1569, Grand Junction, Colorado 81501. Checks or money orders should be made out to Bendix Field Engineering Corporation, the operating contractor for DOE's Grand Junction Office. 


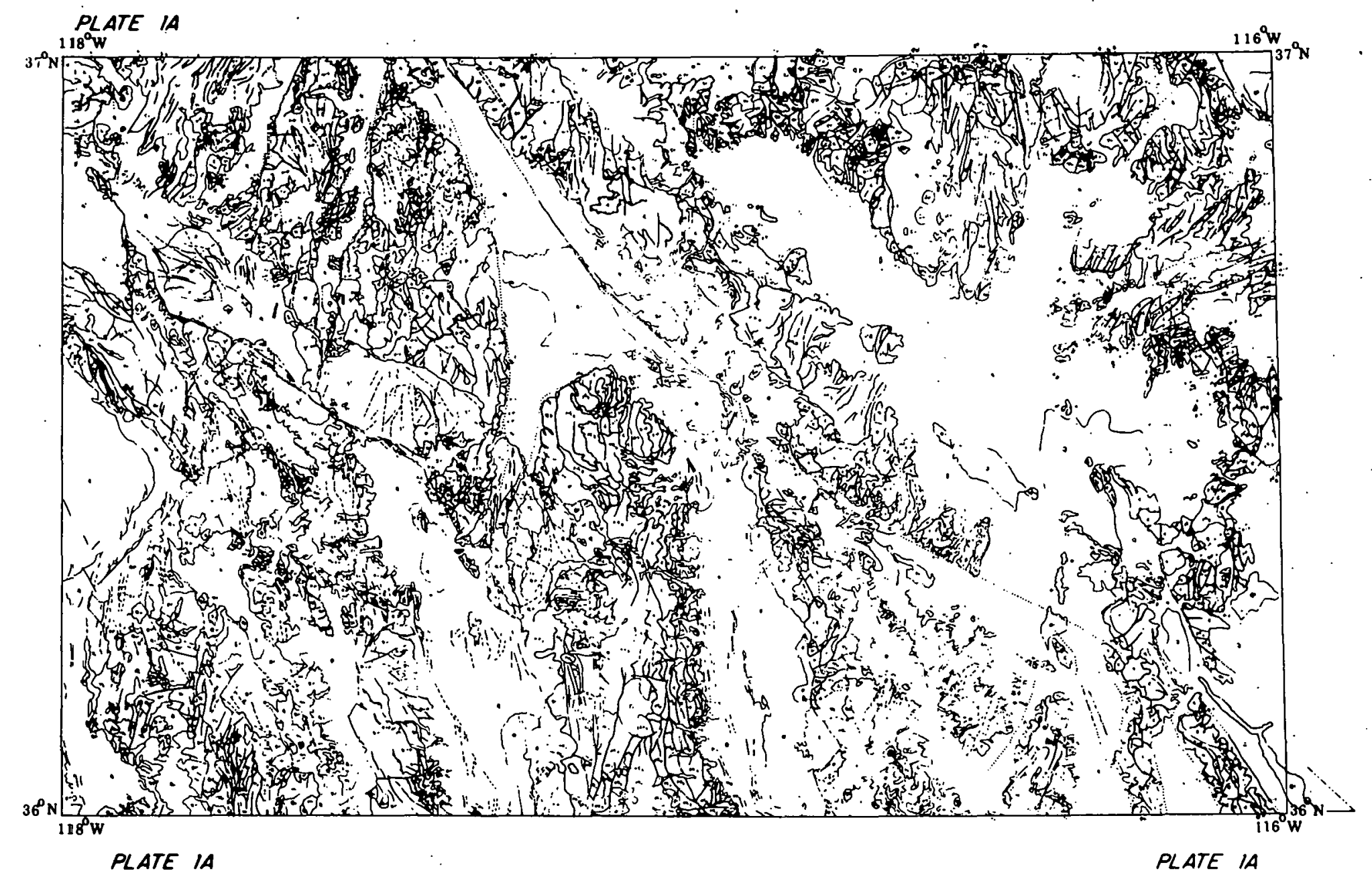




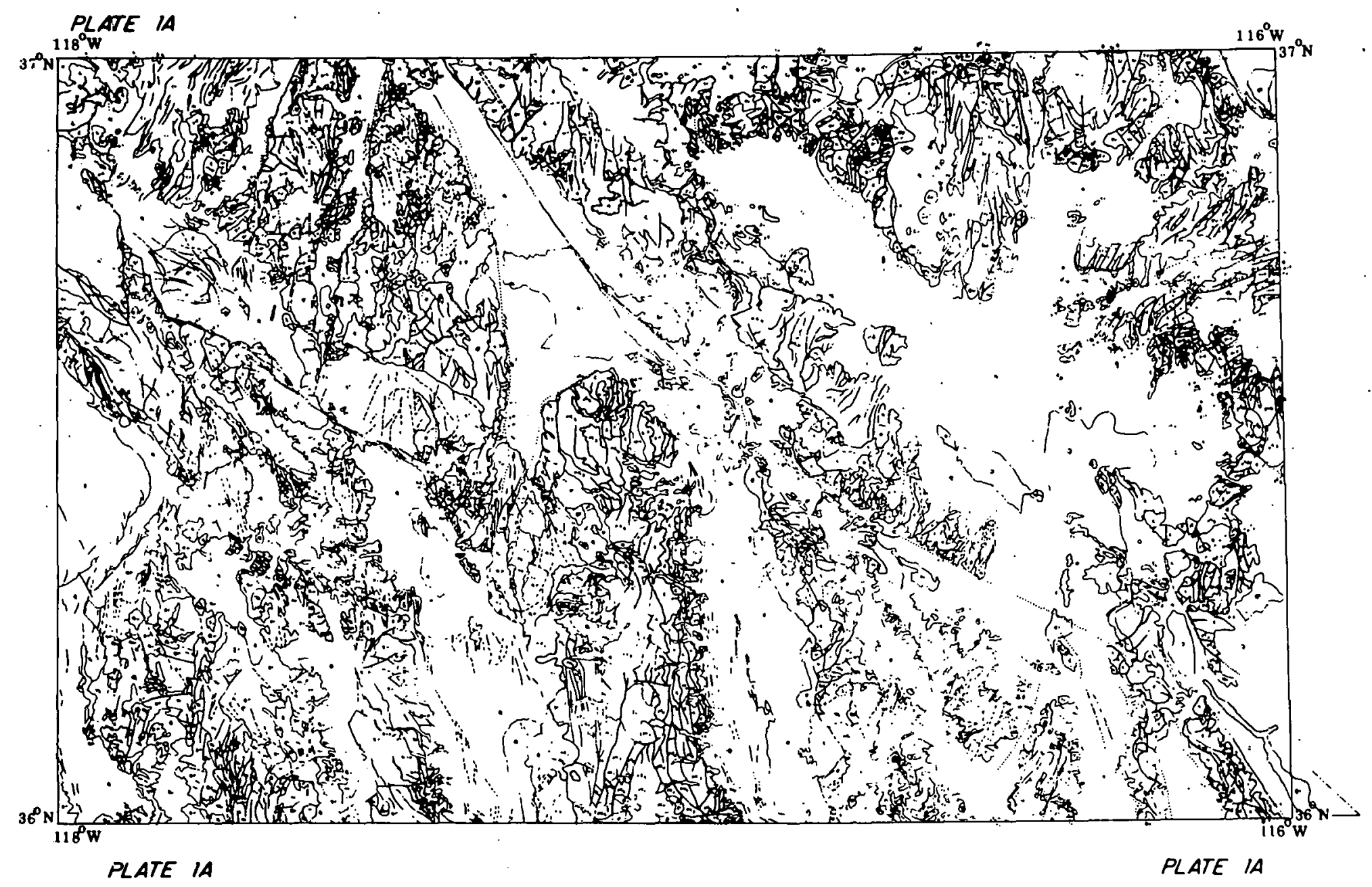







PLATE 1 - B
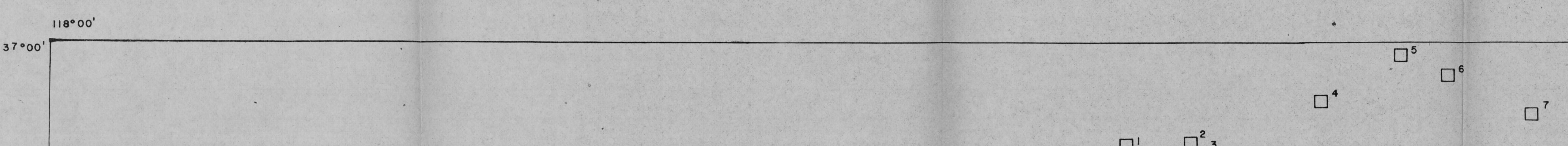

$\left.\bigsqcup_{12}^{16,17}\right]_{12,15}$

口' $\square^{2}$

$\square_{11}^{\square 12}$

$\square 19,20$

$\square^{21,22}$

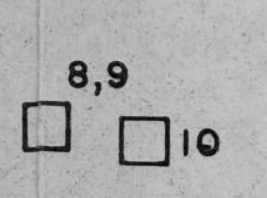

DEATH VALLEY, CALIFORNIA, NEVADA

PLATE 1 - B 
PLATE 1 - C



PLATE 1-C

PLATE 1 - C

EXPANATION

PM Procius Metals

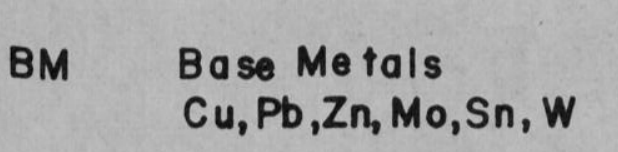

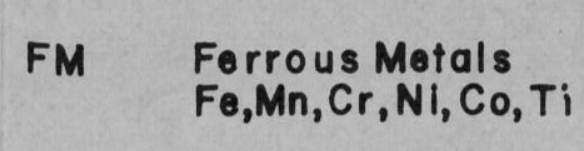

$F-B \quad F, L, B, B, B a, B \theta$

$\triangle$ Uranlum-Radiometric anomaly 
PLATE 2

$z 118^{\circ} \mathrm{W}$
$0 \hat{n}+\cdots+\cdots+\cdots+$
के

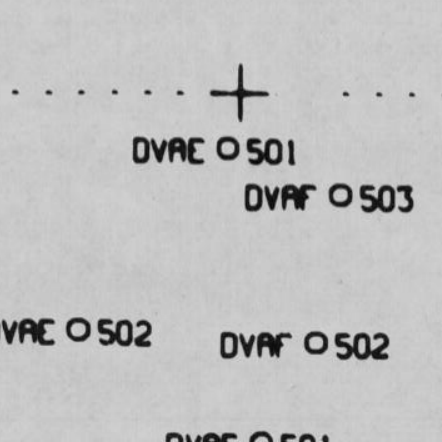
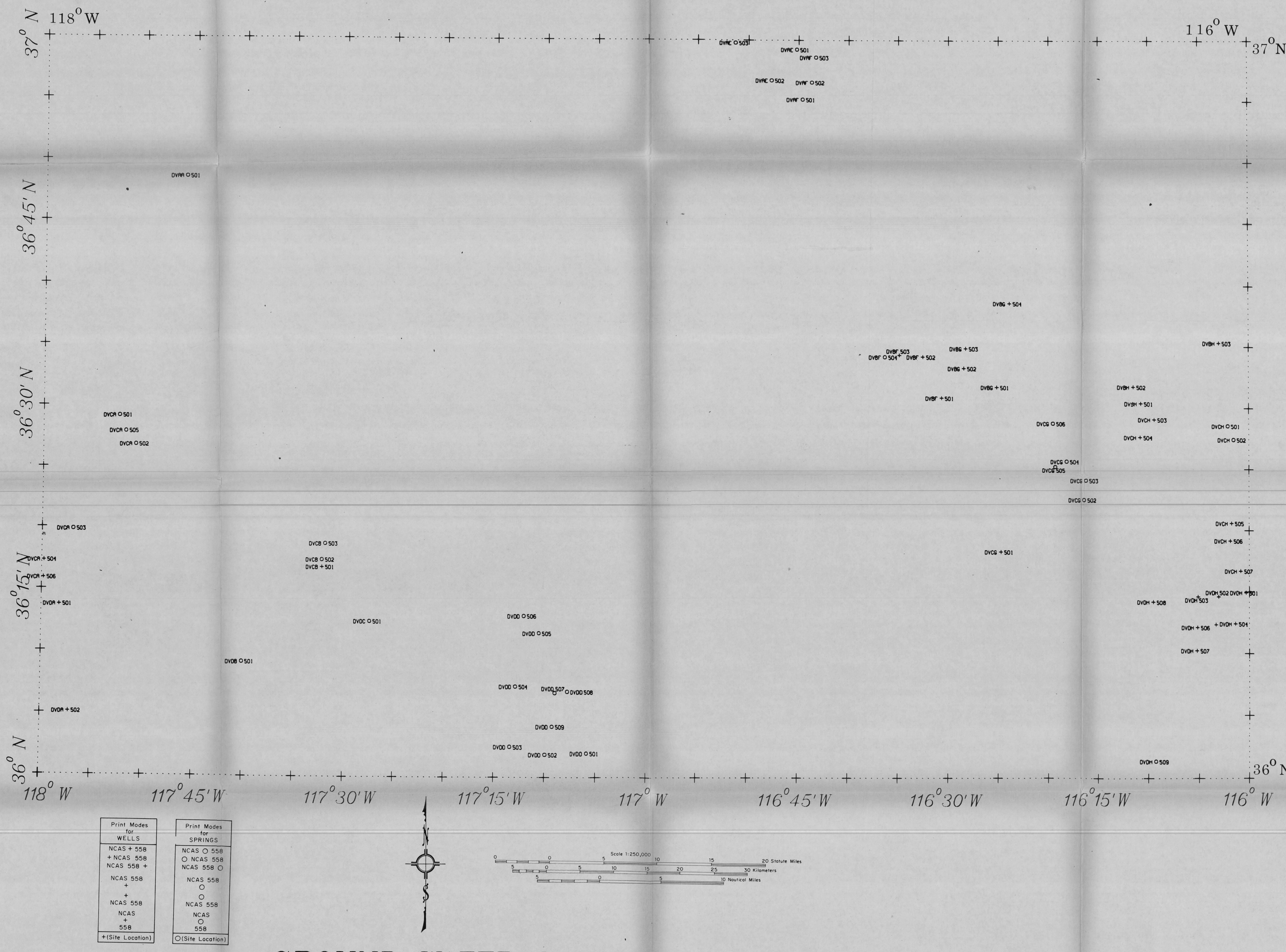

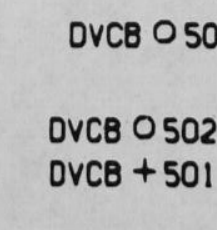

$\ldots$

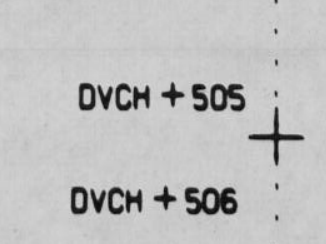

ancoses

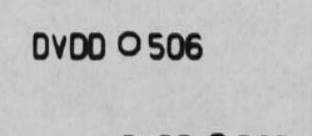

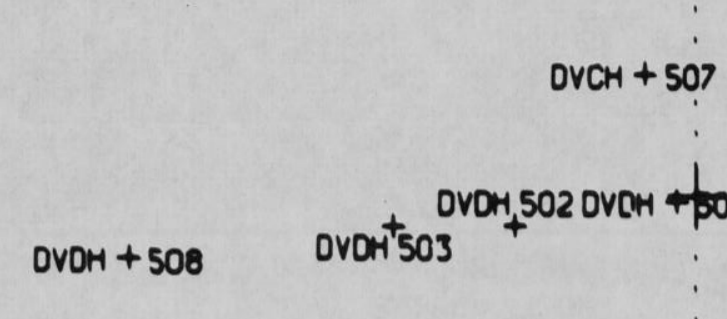

over +500 + $+000+500$ :

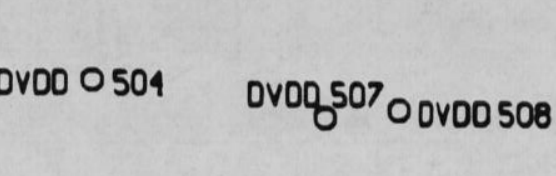

0010005053001000502000000501

$117^{\circ} 30^{\prime} \mathrm{W}$

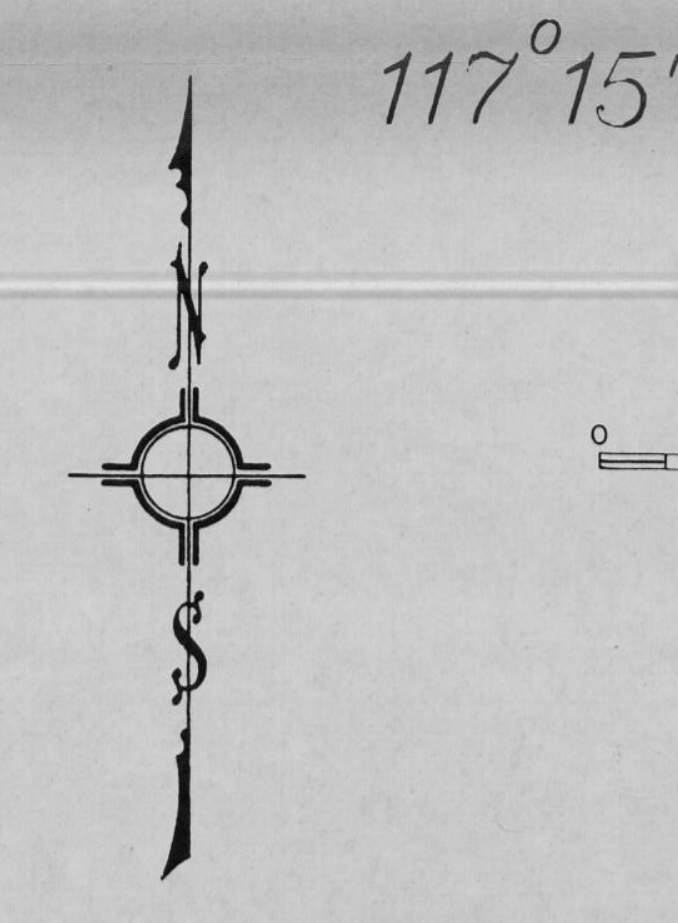

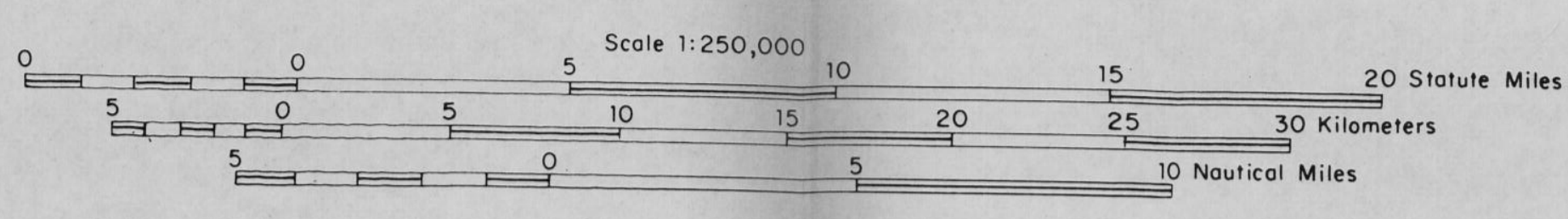

$116^{\circ} 30^{\prime} \mathrm{W}$

$116^{\circ} 15^{\prime} \mathrm{W}$

$116^{\circ} \mathrm{W}$

GROUND WATER SAMPLE SITE LOCATIONS 
PLATE 3

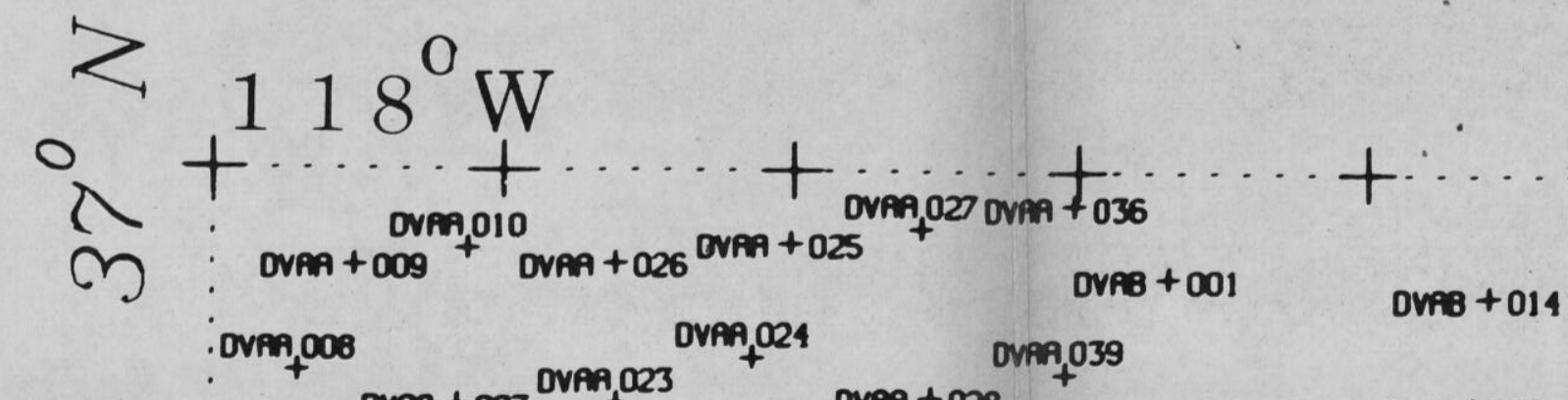

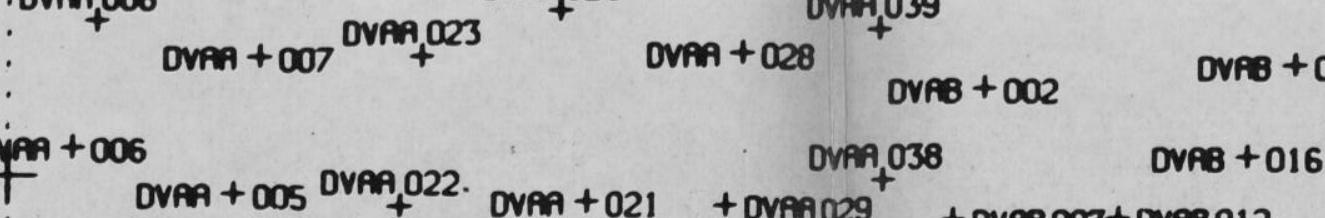

intros

antion

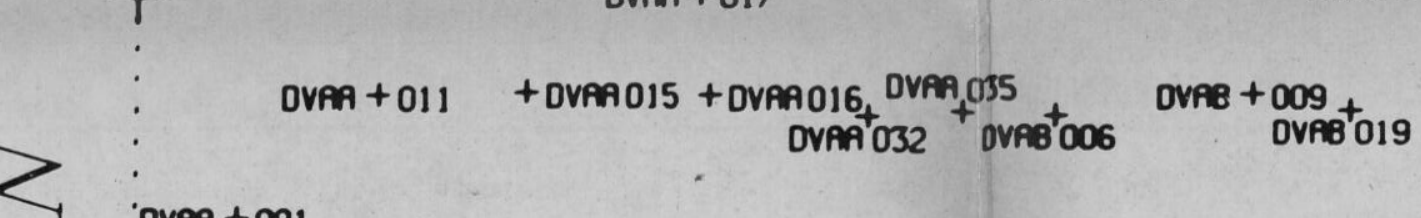

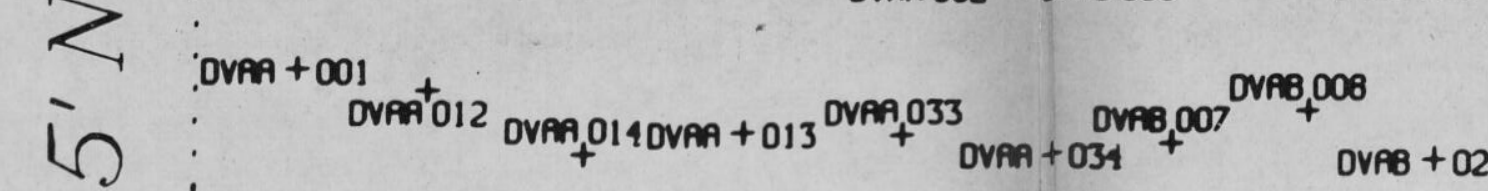

Font tort

Maint tor

Intore

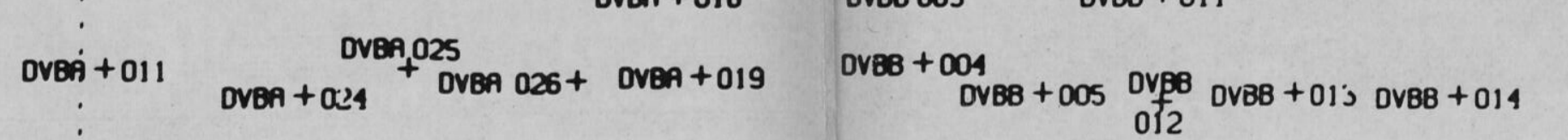

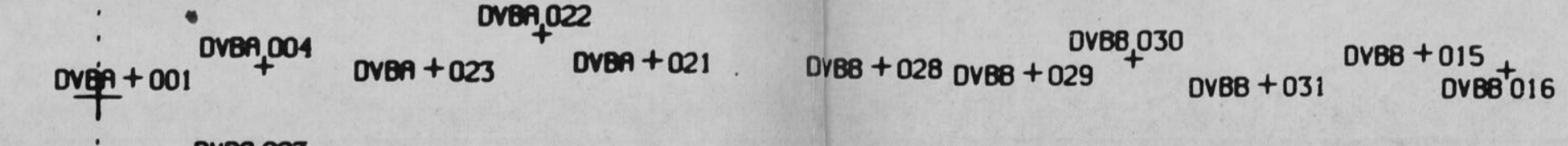

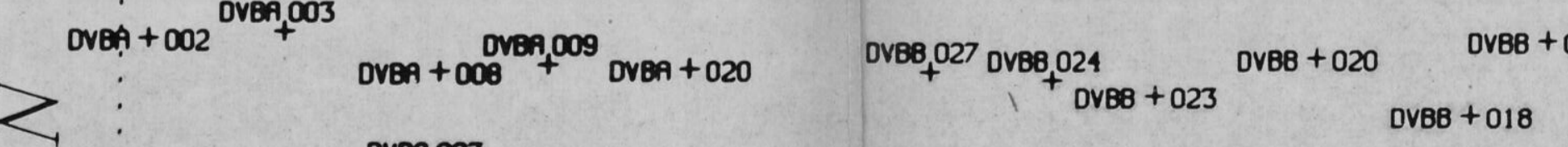

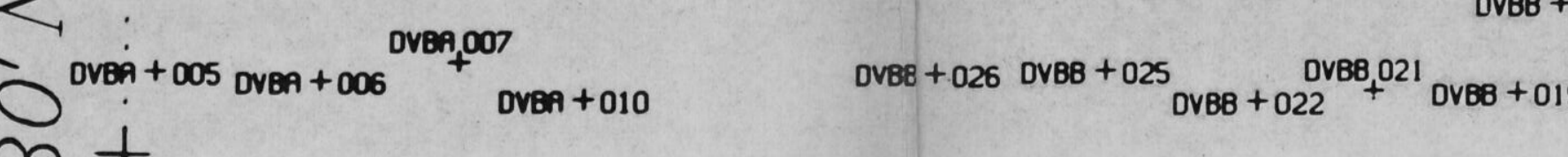

C):

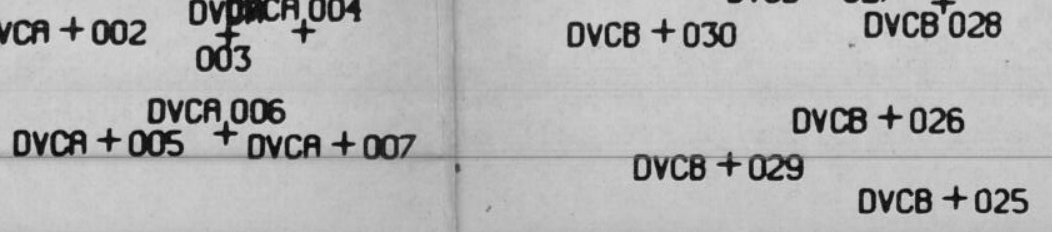

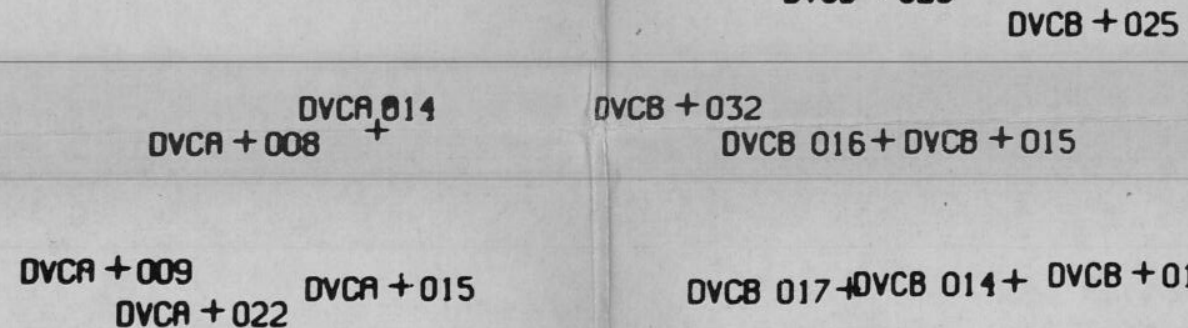

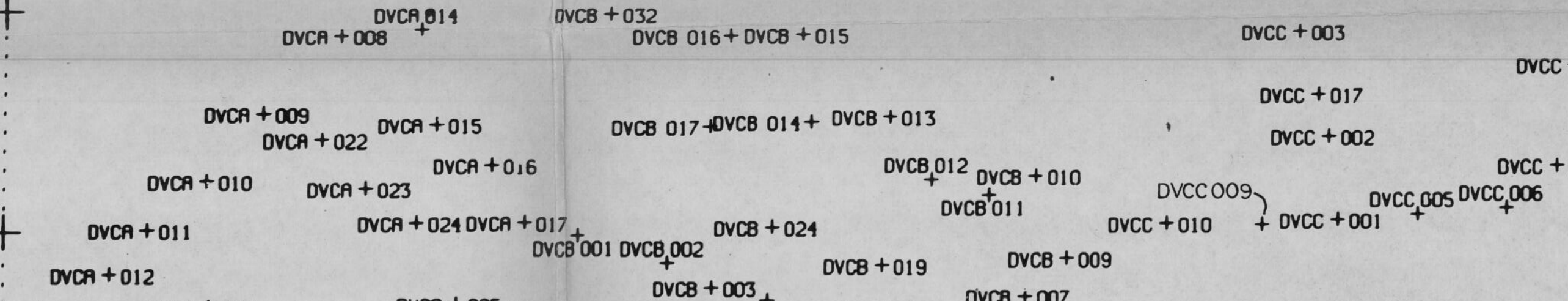

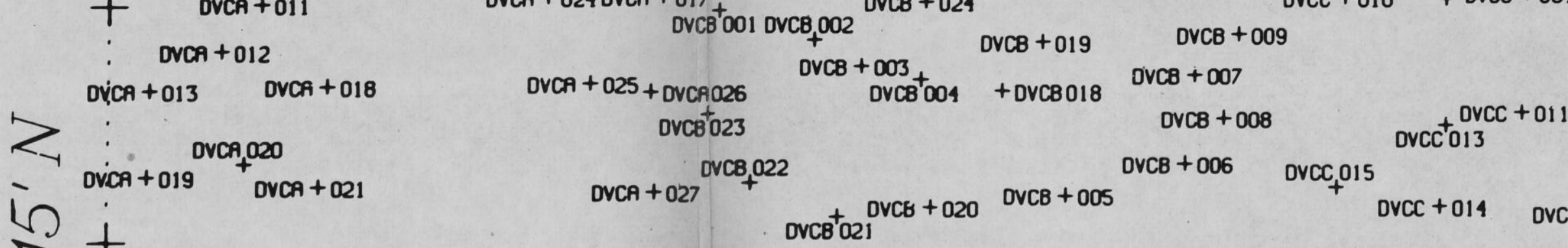

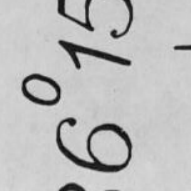

inat tou

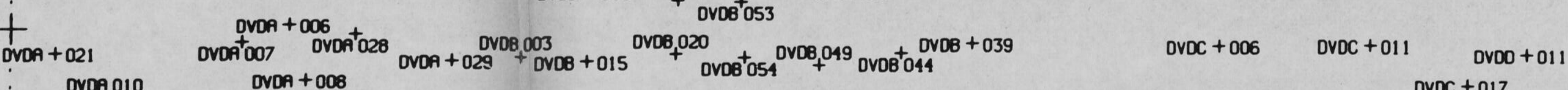

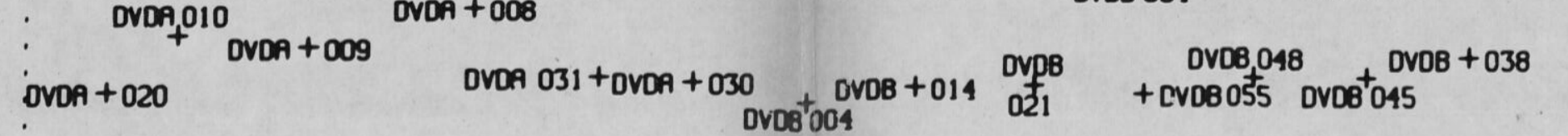

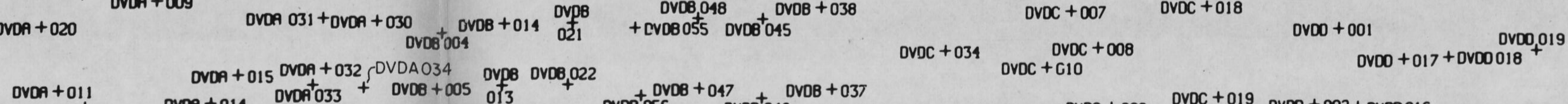

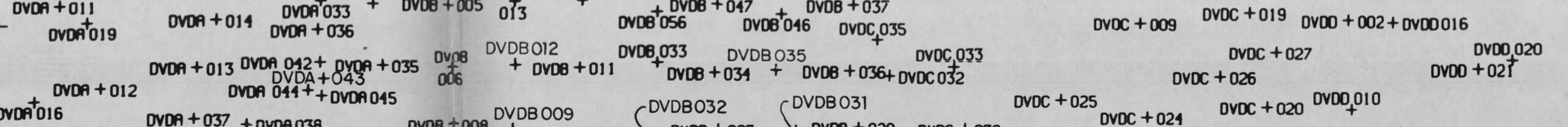

$0+$

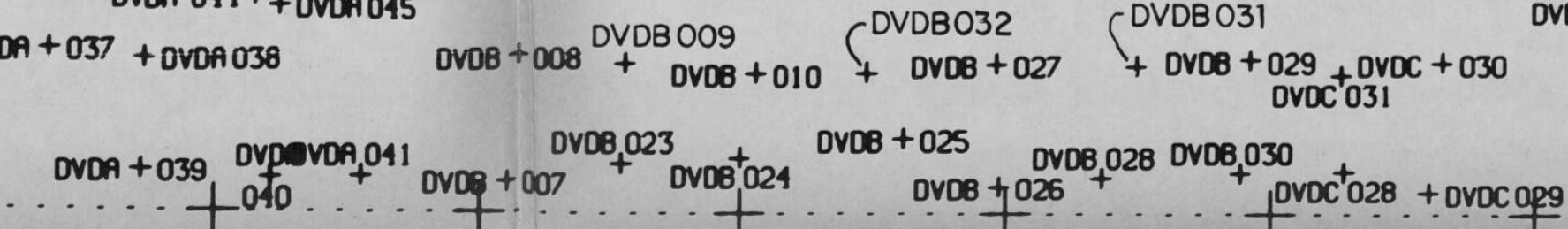

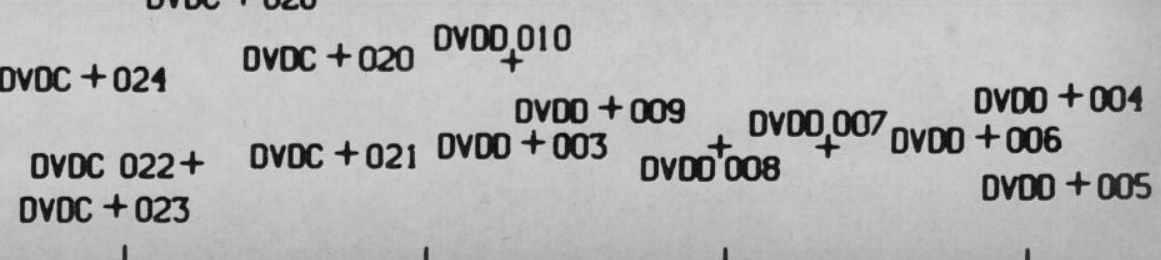

$\begin{array}{lll}117^{\circ} 45^{\prime} \mathrm{W} & 117^{\circ} 30^{\prime} \mathrm{W}\end{array}$

$+117^{0} 15^{\prime} \mathrm{W}+\cdots+\cdots+\cdots$

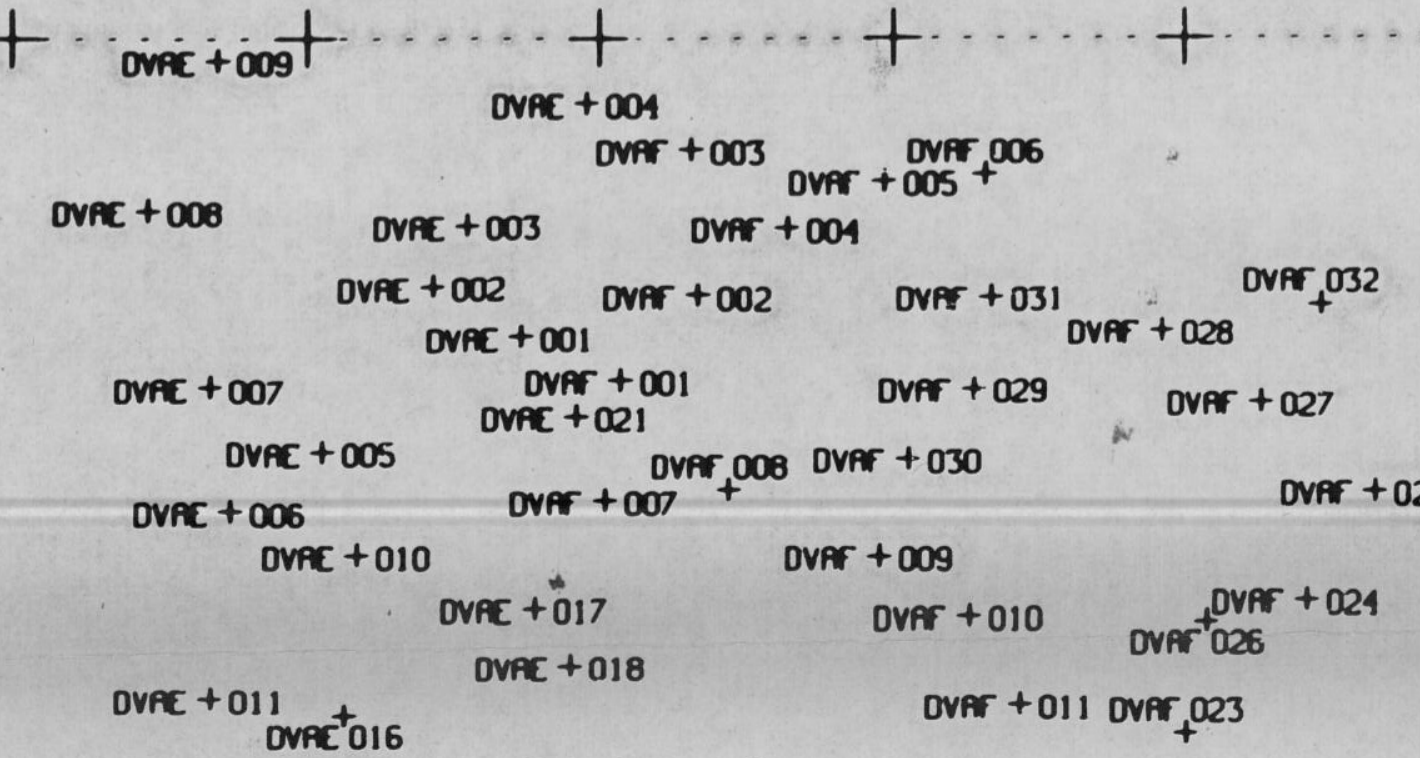

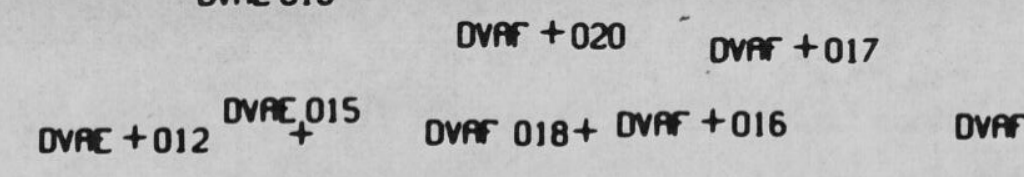

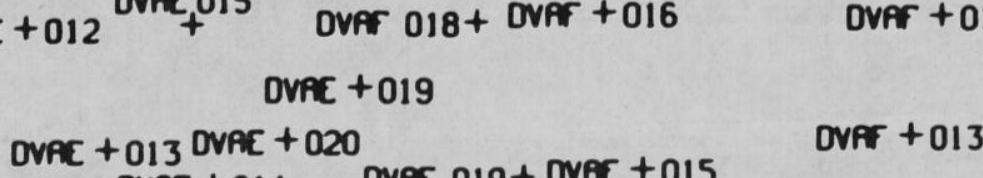

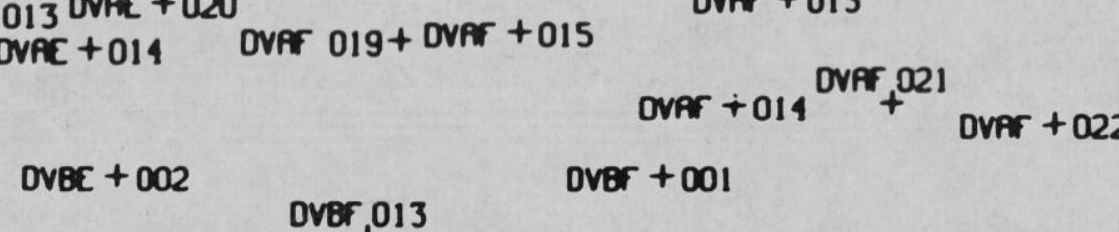

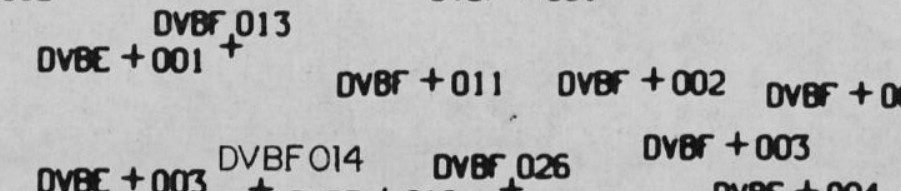
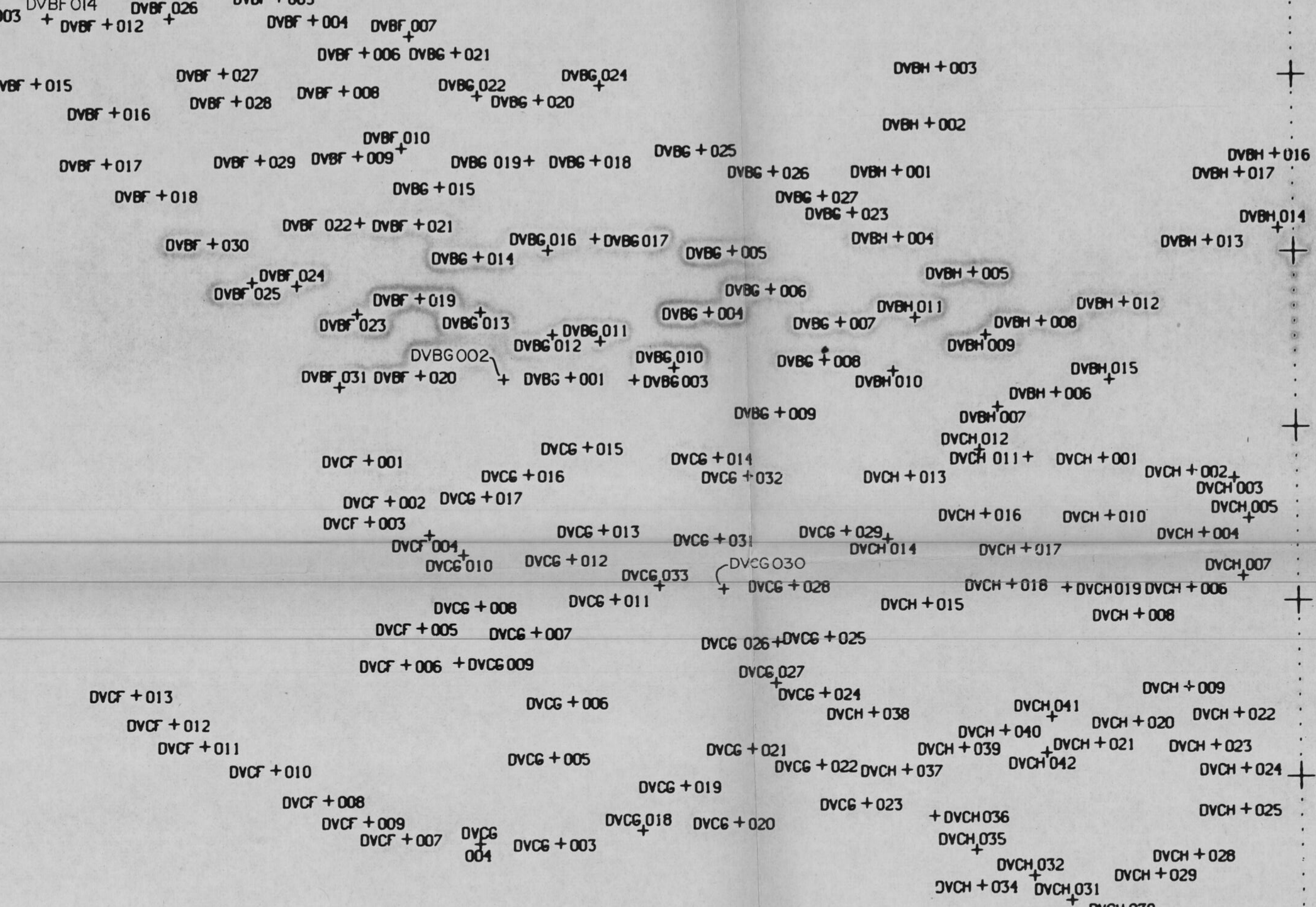

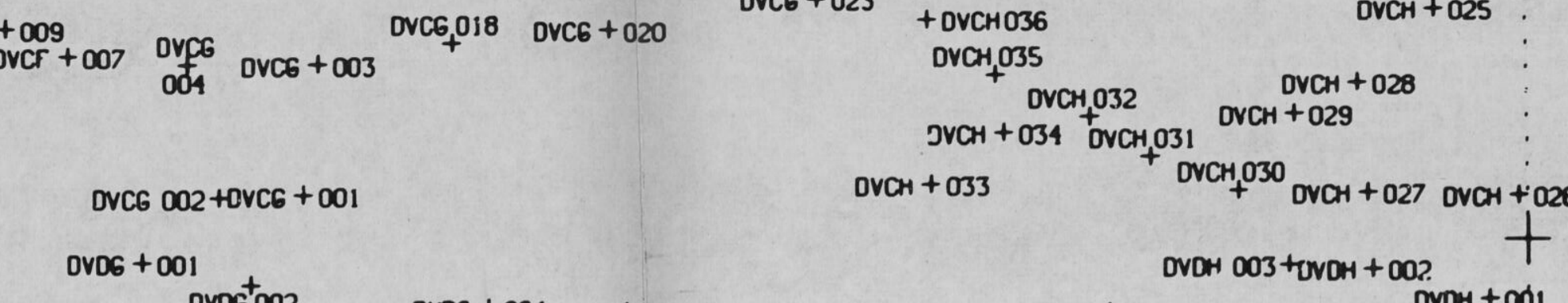

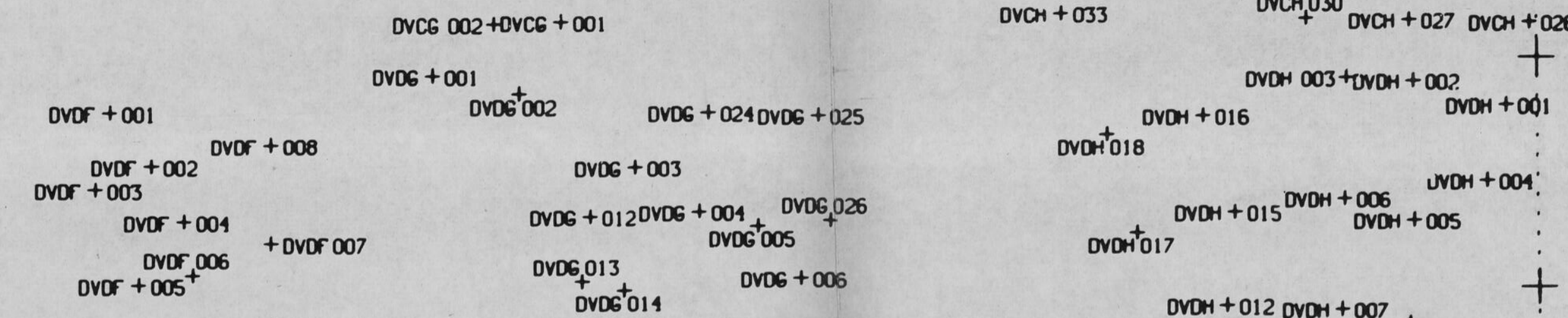

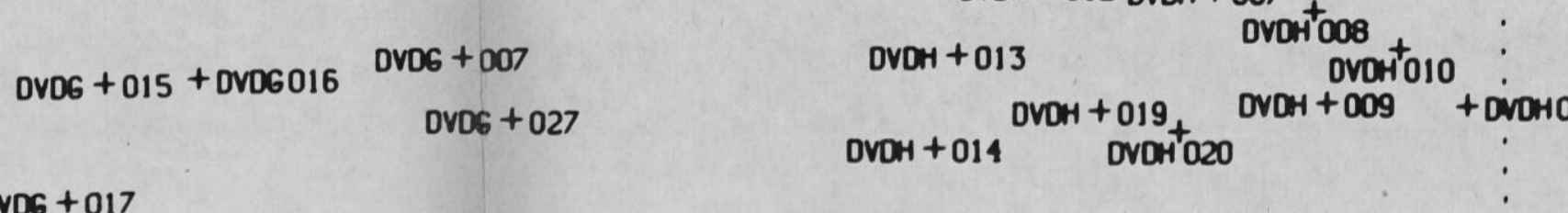

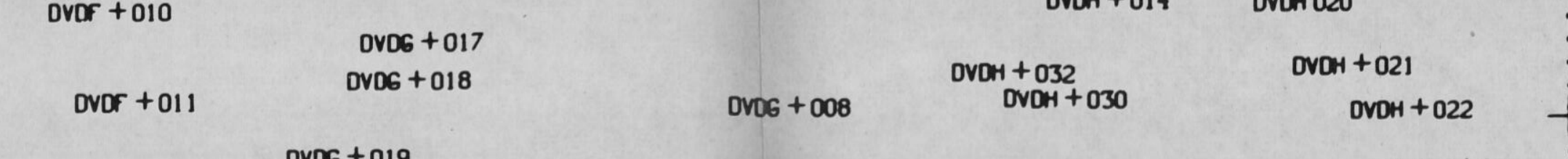

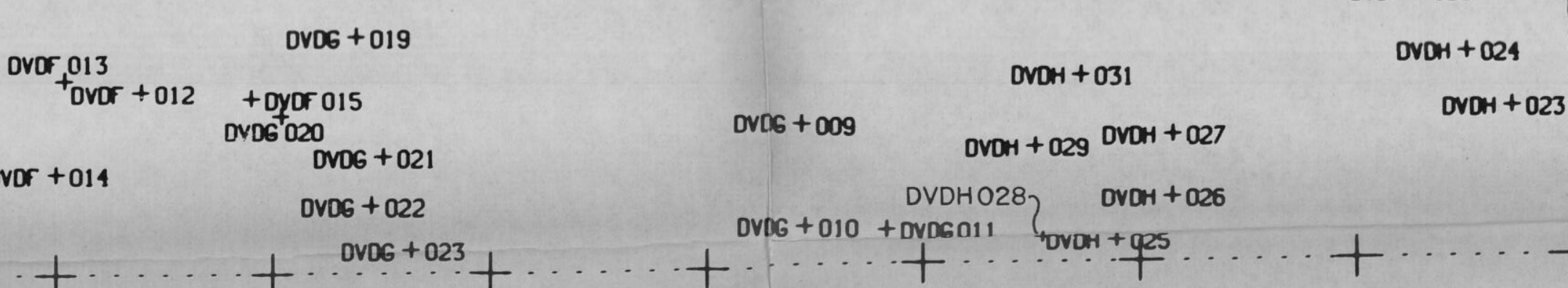
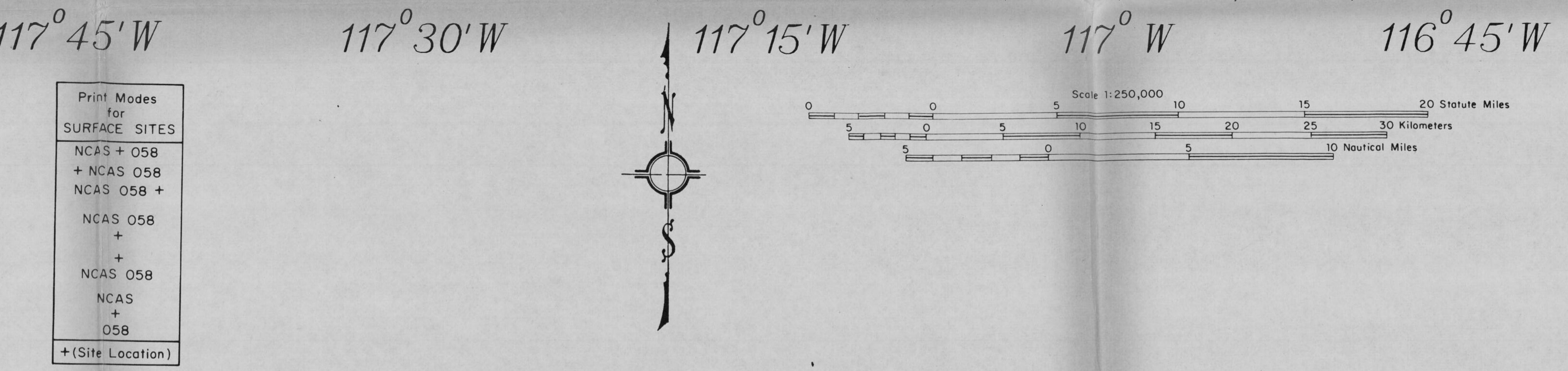

$116^{\circ} 30^{\prime} \mathrm{W}$

$116^{\circ} 15^{\prime} \mathrm{W}$

$116^{\circ} \mathrm{W}$

SURFACE SAMPLE SITE LOCATIONS 
PLATE 4

$$
\begin{aligned}
& z 118^{\circ} \mathrm{W} \\
& \hat{i}+
\end{aligned}
$$

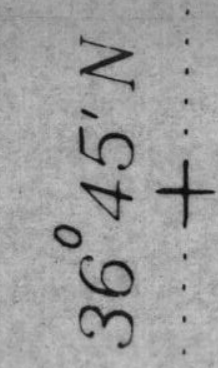

产+

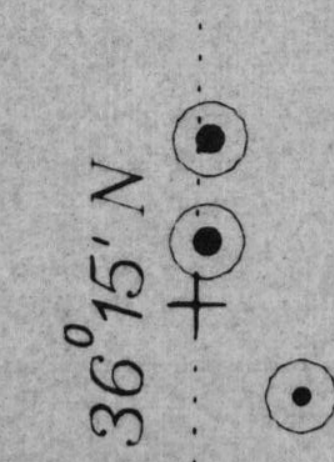

8

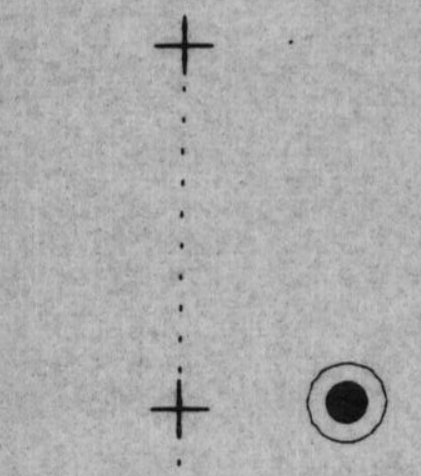

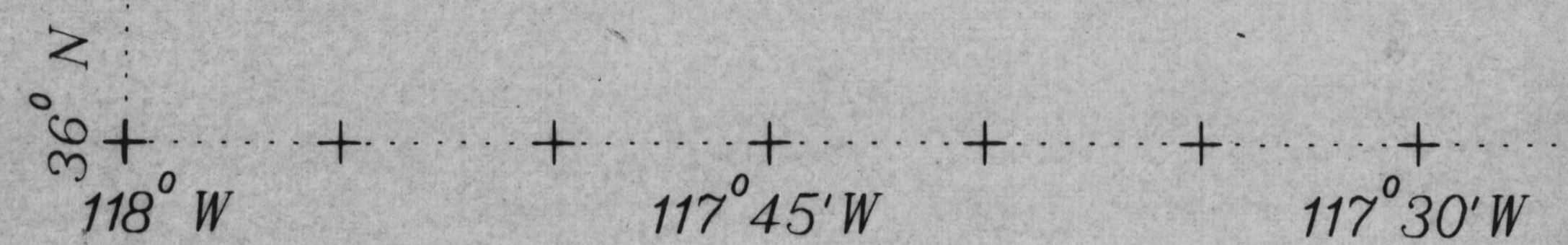
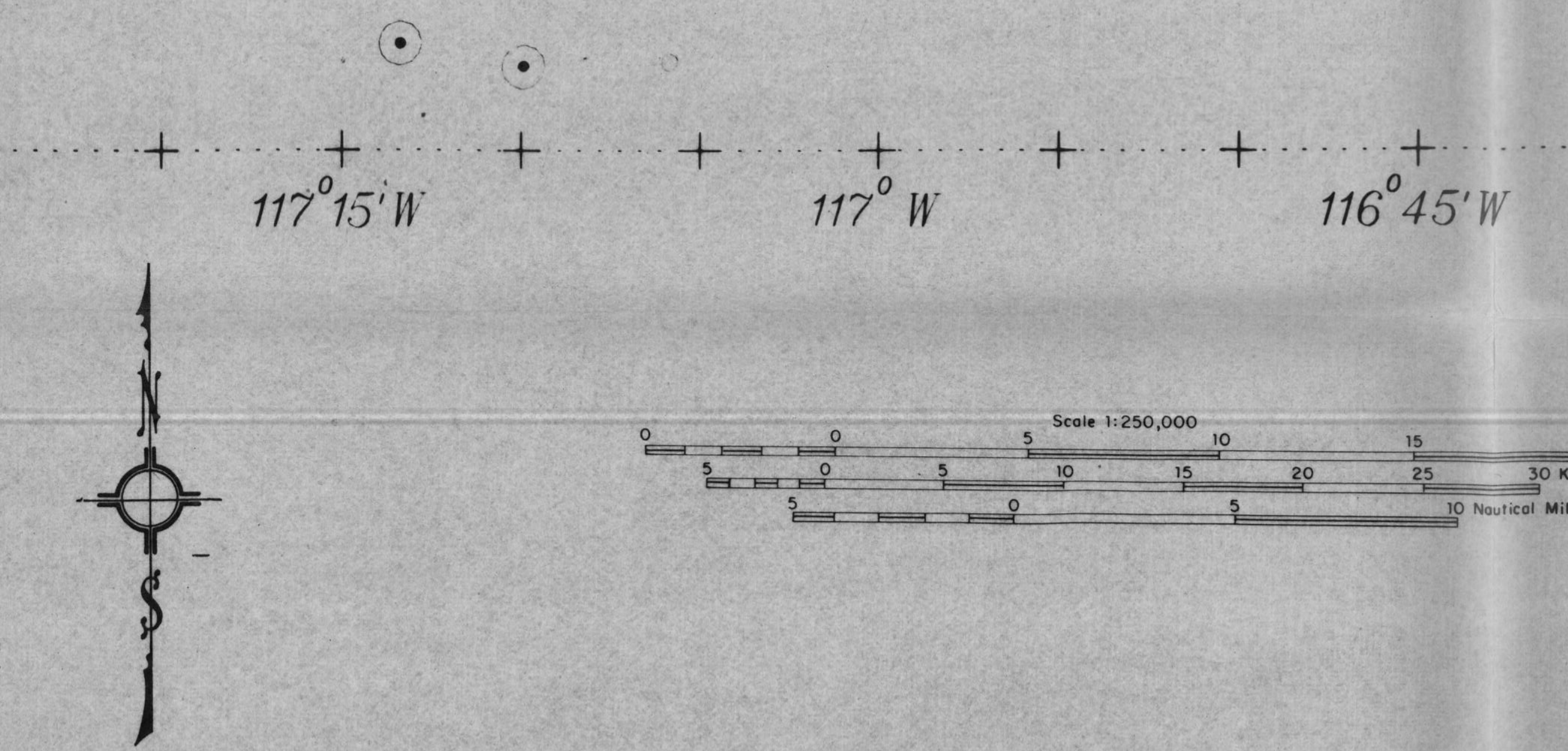

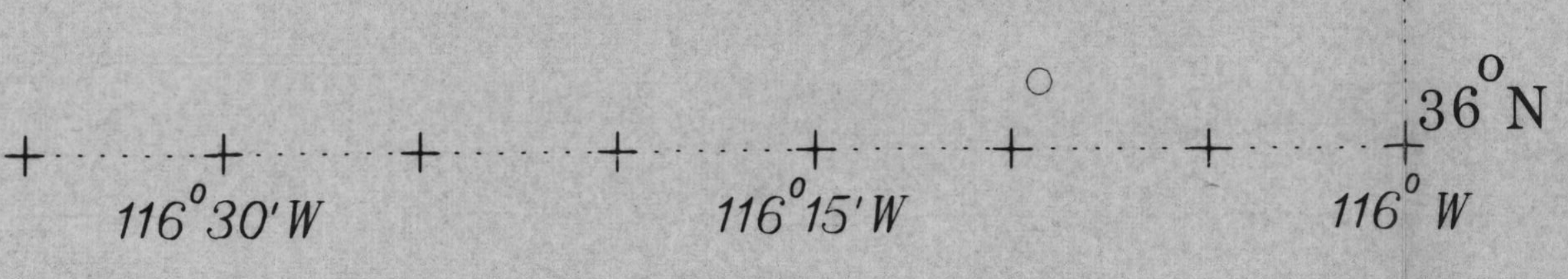


URANIUM DISTRIBUTION IN THE GROUND WATERS 

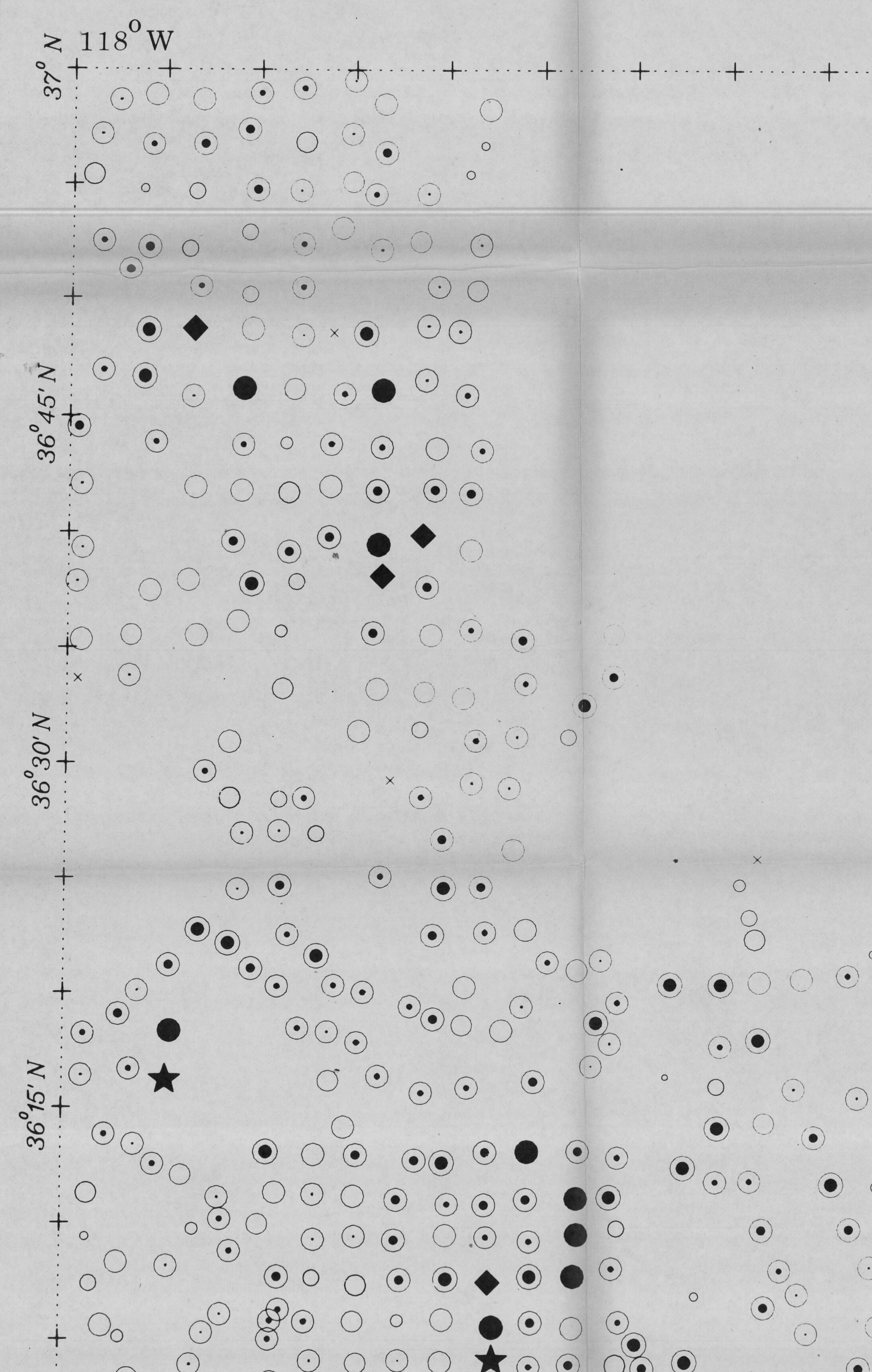

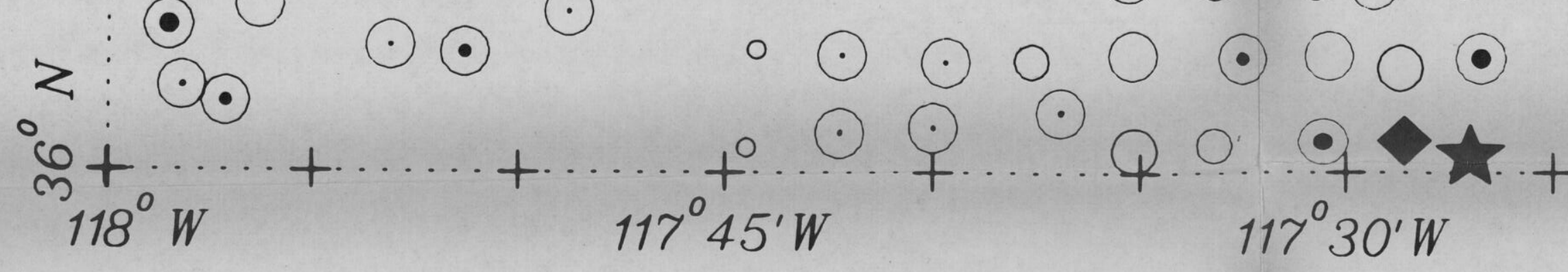
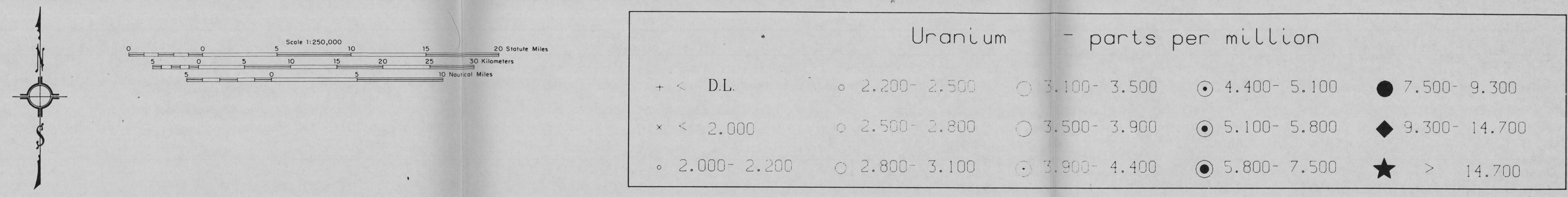

URANIUM DISTRIBUTION IN THE SEDIMENTS 
PLATE 6

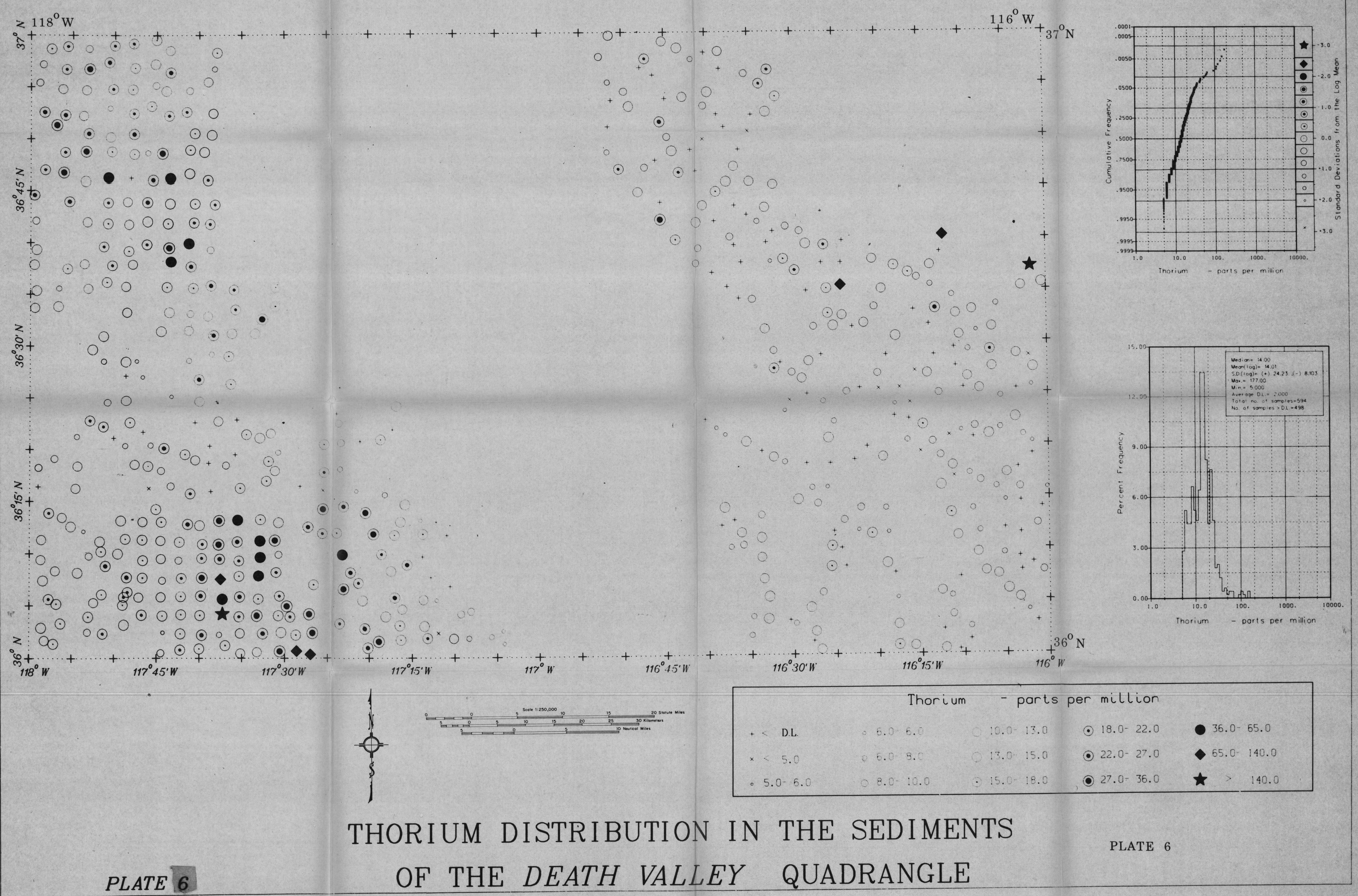




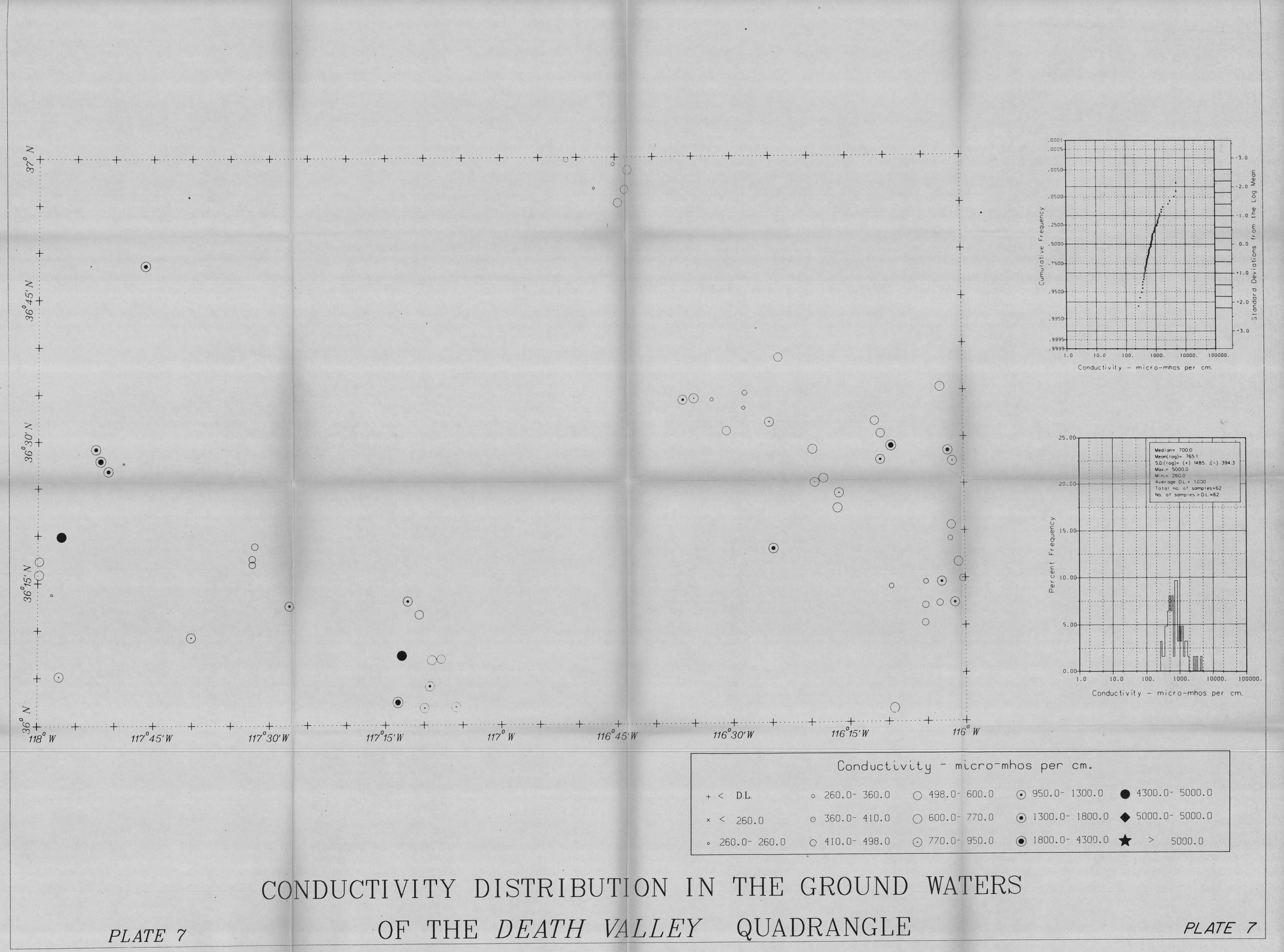

